\title{
To binge or not to binge, that's the question : a critical examination of the conditioning model of binge eating
}

Citation for published version (APA):

Nederkoorn, C. (2002). To binge or not to binge, that's the question : a critical examination of the conditioning model of binge eating. [Doctoral Thesis, Maastricht University]. Datawyse / Universitaire Pers Maastricht. https://doi.org/10.26481/dis.20020412cn

Document status and date:

Published: 01/01/2002

DOI:

10.26481/dis.20020412cn

Document Version:

Publisher's PDF, also known as Version of record

\section{Please check the document version of this publication:}

- A submitted manuscript is the version of the article upon submission and before peer-review. There can be important differences between the submitted version and the official published version of record.

People interested in the research are advised to contact the author for the final version of the publication, or visit the DOI to the publisher's website.

- The final author version and the galley proof are versions of the publication after peer review.

- The final published version features the final layout of the paper including the volume, issue and page numbers.

Link to publication

\footnotetext{
General rights rights.

- You may freely distribute the URL identifying the publication in the public portal. please follow below link for the End User Agreement:

www.umlib.nl/taverne-license

Take down policy

If you believe that this document breaches copyright please contact us at:

repository@maastrichtuniversity.nl

providing details and we will investigate your claim.
}

Copyright and moral rights for the publications made accessible in the public portal are retained by the authors and/or other copyright owners and it is a condition of accessing publications that users recognise and abide by the legal requirements associated with these

- Users may download and print one copy of any publication from the public portal for the purpose of private study or research.

- You may not further distribute the material or use it for any profit-making activity or commercial gain

If the publication is distributed under the terms of Article $25 \mathrm{fa}$ of the Dutch Copyright Act, indicated by the "Taverne" license above, 


\title{
To binge or not to binge, that's the question
}

\author{
A critical examination of the \\ conditioning model of binge eating
}


Idee onslag: Frank van der Panne

Productie: Datawyse | Universitaire Pers Maastricht

ISBN 90-9015663-1 


\title{
To binge or not to binge, that's the question
}

\author{
A critical examination of the \\ conditioning model of binge eating
}

Proefschrift

ter verkrijging van de graad van doctor aan de Universiteit Maastricht, op gezag van de Rector Magnificus, Prof. dr. A.C. Nieuwenhuijzen Kruseman volgens het besluit van het College van Decanen, in het openbaar te verdedigen op vrijdag 12 aprill $2002 \mathrm{om} \$ 6.00$ utur

door

Chantal Nederkoorn 
Promotor:

Prof. dr. A.T.M. Jansen

Beoordelingscommissie:

Prof. dr. H.L.G.J. Merckelbach (voorzitter)

Prof. dr. A. Arntz

Prof. dr. C. Braet (Universiteit Gent)

Dr. P. de Jong

Dr. U. Stockhorst (Heinrich Heine University Düsseldorf) 


\section{Contents}

1. Binge eating: an introduction 7

Methods for measuring the saliva response 23

2. Recording of swallowing events using electromyography 25 as a non-invasive measurement of saliva

3. Experimental comparison of different techniques to measure saliva

Conditioning model of binge eating

4. Cephalic phase responses, craving and food intake in normal subjects

5. Cue reactivity and regulation of food intake

6. Is cue reactivity a good predictor of binge eating in bulimic women?

7. General discussion

Summary

Samenvatting

References

Dankwoord

Curriculum Vitae 



\title{
1. Binge eating: an introduction
}

\begin{abstract}
This thesis is about binge eating. But what does binge eating mean? During an eating binge, a large amount of food is eaten, while the eater feels out of control. Binge eating is part of several eating disorders and interferes with functioning in daily live. 'Two theories on binge eating, the boundary model and the conditioning model of binge eating, are discussed. The boundary model suggests an intermediating role of disinhibitive thoughts in binge eating, however, no support for this assumption has been found. The conditioning model of binge eating assumes that certain cues predict an eating binge; exposure to these cues evokes reactivity, which is experienced as craving for food and causes an eating binge. The evidence provided in the literature for these assumptions is not conclusive. Because the conditioning model might play an important role in explaining the mechanisms underlying binge eating, in that way providing new therapy methods for eating disorders, research in this thesis will be aimed at testing this model.
\end{abstract}




\section{The clinical picture}

The scope of this thesis is binge eating. Binge eating is a phenomenon as old as human kind: already in the bible it is mentioned as one of the seven deadly sins. Besides pride, envy, lust, anger, greed and sloth, gluttony is listed as an inordinate desire to consume more than what is required. Nowadays, in psychology science, binge eating is regarded as a disorder instead of a sin, and people should be treated instead of being punished.

Yet, what is a binge? During a clinical eating binge, an abnormally large amount of food is eaten, while the binge eater feels a lack of control over his (or more often: her) eating behaviour. Possible additional characteristics are that the subject eats much more rapid than normal, eats until being uncomfortably full and eats large amounts of food when not feeling physically hungry. Moreover, the subject often eats alone because of being enbarrassed by how much one is eating and feels disgusted with oneself, depressed or very guilty after overeating (APA, 1994). Binges often are rituals. Jansen, van den Hout, de Loof, Zandbergen and Griez (1989) describe an eating binge of a patient with bulimia nervosa. The patient first puts on comfortable clothes, arranges all the binge food items (e.g. ice cream, chocolate, cookies, shortbread, liquorice, bananas, currant buns and milk) on a tray and sits down on her couch. She picks up a special magazine and starts reading, meanwhile stuffing herself with all the food in about a quarter of an hour. After bingeing, the patient vomited. The patient had an average of five binges a week for over seven years and alternated binge eating episodes with strict dieting episodes, in which she merely ate healthy food. The patient also had dysfunctional thinking patterns and low mood.

This example illustrates that an eating binge is more than just eating too many sweets once in a while. The lives of binge eaters are dramatically influenced by food intake and by extreme concerns about their weight and body shape and, in many cases, this can prevent the patient to function normally. Eating disorders, including binge eating, are associated with higher general dissatisfaction (Rosenvinge, Borgen \& Börresen, 1999), and obese binge eaters have lower self-esteem (Decaluwé \& Braet, 2001 ) and more negative self-schemas (Nauta, Hospers, Jansen \& Kok, 2000) than obese non-binge caters. In addition, subjects with eating binges often suffer from negative moods; in act empirical data demonstrates a high incidence of depression among binge eaters (Cooper \& Fairbum, 1986; Swift, Andrews \& Barklage, 1986). Finally, there are several health consequences associated with eating disorders (Jansen, 1998 a). In sum, binge eating has substantial impact on a person's life and well being. Whether binge eating should be regarded as a sin or a disorder, it is clear that a cure would be a blessing. 


\section{Definitions and prevalence}

The exact definition of binge eating in DSM IV (APA, 1994) is eating, in a discrete period of time (e.g., within any 2-hour period), an amount of food that is definitely larger than most people would eat during a similat period of time and under sinular circumstances. Secondly, there is a sense of lack of control over eating during the episode (e.g., a feeling that one cannot stop eating or control what or how much one is eating).

The caloric value and nutrient composition of a binge vary largely between and within subjects. In an overview of several studies a mean intake of over 1000 kilocalories in an eating binge is reported (Guertin, 1999). Larger inlake is reported in studies in which the participants were instructed to binge in a laboratory setting, compared to diary studies. All kinds of food are reported but often "forbiclden foods" are eaten during a binge, like chocolate, ice cream and cake, all high in calories (Rosen, Leitenber, Fisher \& Khazam, 1986; Walsh, 1993). Nevertheless, it was repeatedly found that the macronutrient composition of eating binges does not differ from normal meals (Jansen, van den Hout \& Griez, 1990; Rossiter, Agras, Telch \& Bruce, 1992; Walsh., 1993).

Binge eating is an important component of several eating disorders, namely bulimia nervosa, anorexia nervosa and binge eating disorder. In the delinition of bulimia nervosa (APA, 1994), binge eating and inappropriate compensatory behaviours (e.g., self-induced vomiting; misuse of laxatives, diuretics or enemas; fasting or excessive exercise) both occur, on average, at least twice a week for 3 months. Other diagnostic criteria of bulimia nervosa are irrational ideas about one's figure, appearance and weight. Nearly half of the patients with anorexia nervosa, namely the binge-eating/purging type, also regularly engage in binge eating or purging (or both), most individuals at least weekly. Main criteria for anorexia nervosa is a refusal to maintain body weight at or above a minimally normal weight for age and height, intense fear of gaining weight and disturbances in the way one's body weight or shape is experienced. Finally, in DSM IV (APA, 1994) binge eating disorder (BED) is introduced, categorised under eating disorder not otherwise specified (EDNOS). This disorder is defined as having recurrent episodes of binge eating in the absence of the regular use of inappropriate compensatory behaviours characteristic of bulimia nervosa.

The prevalence of binge eating can be calculated approximately by adding up the different eating disorders. Anorexia nervosa has a prevalence of $0.5-1 \%$ under women, and the binge eating purging type about the half of it (Hoek, 1995), bulimia nervosa 1-3 \% (APA, 1994; Jansen, 1998a; Kinzl, Traweger, Trefalt, Mangweth \& Biebl, 1999; Rosenvinge et al. 1999; Westerhoefer, 2001). Binge eating disorder has a prevalence of $0.7-4 \%$ overall, with women having one and a half more chance (APA, 1994). Hence, together between 2 and $8 \%$ of all women have eating binges. Binge eating has also been documented in non-clinical nomal weight populations, 12 to 20 $\%$ of women in a large population sample reported binge eating (Bruce \& Agras, 1992 ; Kinzl et al., 1999; Wardle \& Beinhart, 1981).

The reported incidence of eating disorders is substantial less in men, allhough 
the statistics vary widely. Westenhoefer (2001) found no difference in prevalence of binge eating between men and women. Field et al. (1999) found $30 \%$ of the binge eaters to be male, Heatherton, Nichols, Mahamedi and Keels (1995) about 20\%. According to APA, the male to female ratio in patients with anorexia nervosa and bulimia nervosa is usually 1:10 (APA, 1994) and Rosenvinge et al. (1999) only found clinical and subclinical eating disorders among girls and not among boys, all aged fifteen.

\section{Aetiology and maintenance}

An important question is why people start having eating binges. Cultural factors are supposed to be an important factor (Romans, Gendall, Martin, \& Mullen, 2001). On personal level, the most common antecedents associated with binge eating and eating disorders are perfectionism, low self-esteem (Fairburn \& Cooper, 1989; Loro \& Orleans, 1981; Mizes \& Christiano, 1995) and negative mood (Heatherton \& Baumeister, 1991; Polivy \& Herman, 1993). Further reported risk factors are restrained eating behaviour (Fairburn \& Garner, 1988; Polivy \& Herman, 1985) and stressful life-events (Lacey, Coker \& Birtchnell, 1986). Multi-factorial approaches stress that, given the heterogeneity of the women with eating disorders, unidimensional models cannot explain the aetiology of eating disorders (Beebe, Holmebeck, Albright, Noga \& Decastro, 1995; Striegel-Moore, Silberstein \& Rodin, 1986). For example, the co-occurrence of depression and dietary restraint predicts binge eating (Greenberg, 1986) and Beebe et al. (1995) found that higher depression scores, lower self-esteem, chaotic eating patterns and higher levels of seliconsciousness characterised binge-prone women.

Although a concept of the risk factors for binge eating is established, there are some issues that need to be addressed. First, the causal relationship between binge eating and mood or personality characteristics is not clear. For instance, is a negative mood an antecedent or consequence of abnormal eating behaviour? Second, many suspected factors, like stressful life events, are not specific for binge eating (Fairbum, Welch, Doll, Davies \& O'Connor, 1997). And third, in multicausal models a combination of factors causes an eating disorder, which can vary between individuals. In addition, it is claimed that the same combination of factors can have dissimilar effects in different individuals (Garfinkel \& Garner, 1982). Ergo, such models are in risk only to provide descriptions of the phenomenon, instead of predictions or hypotheses.

Another line of research is aimed at the maintenance of binge eating, more specific at what triggers an eating binge. Using reports of bulimic women, Waters, Hill and Waller (2000) found that craving food resulted more often in an eating binge when it was morning, when the bulimic women were alone, and when they ate craved food. Also, cravings that resulted in a binge were associated with lower mood, lower energy levels, higher arousal and lower hunger (Waters, Hill \& Waller, 2001). Davis, 
Freeman and Gamer (1988) found that bulmic patients were more likely than controls to report an unpleasant event within 1 hour prior to an eating binge. Crowther, Sanftner, Bonifazi and Sheperd (2001) found that although stressful days were associated with higher calorie intake, no direct association was found between daily hassles and eating binges.

Experimental research using the preload paradign also found several triggers for binge eating or overeating. This paradigm was derived from the boundary model for regulation of eating, which not only describes triggers, but also tries to explain why these factors trigger binge eating. The boundary model and the preload paradigm will be described below.

\section{Boundary model for the regulation of eating}

A model with large influence is the boundary model of Herman and Polivy (1980). In this model, binge eating is closely related to efforts to restrain food intake. When subjects try to restrict their food intake, they have a self-imposed diet boundary, which determines how much they are allowed to eat. When this boundary is overstepped, subjects lose control over their eating behaviour, and overeat themselves. Herman and Mack (1975), who measured ice-cream consumption in a taste test in students, first showed this disinhibited behaviour experimentally in the preload paradigm. The students were classified as restrained or unrestrained eaters. One third of the subjects received one milkshake prior to the taste test as a preload, one third received two milkshakes and the other third part received no preload. It appeared that restrained eaters ate most after having consumed two milkshakes and least when they did not consume a milkshake. The unrestrained eaters however ate less when the preload was larger. The explanation for this finding is that the restrained eaters broke their dict boundary by eating the preload. This would activate disinhibitive cognitions, like: "I"ve blown my diet, I might as well continue to eat". "These cognitions then, would lead to overconsumption or an eating binge. Since this first experiment, several studies have shown that eating a preload can induce disinhibitive eating behaviour in restrained eaters, however, various other studies found no significant effects (for an overview, see Boon, 1998). But even if it is established that eating a preload iriggers disinhibitive eating behaviour, no evidence has shown that disinhibitive cognitions played a causal role. To test this assumption, restrained eaters were asked to think aloud during the preload (Jansen, Merckelbach, Oosterlaan, Tuiten \& van den Hout, 1988). In this crucial experiment, no disimhibitive thoughts were found. Boon, Stroebe, Schut and Jansen (1998) did found more restraint-relevant thoughts in restrained eaters, and in the restrained non-dieters this was positively related to the amount of food they consumed afterwards in a taste test. However, these cognitions could more adequately be described as inhibitive then disinhibitive cognitions. In sum, experimental research shows that eating a preload is a trigger for binge eating, which is consistent with the diary research of Waters et at. (2000), who found that eating 
craved food was a precursor for binge eating. However, the role of disinhibitive thoughts is questionable.

Using the preload paradigm, it was shown that the experience of negative emotions also increased food intake in restrained eaters (Cools, Schotte \& McNally, 1992: McFarlane, Polivy \& Herman, 1998; Polivy, Herman \& McFarlane, 1994). Herman and Polivy (1984) extended the original model and explained this finding by arguing that the diet boundary becomes irrelevant or ineffective during the experience of strong emotions. Furthermore, they claim that focusing attention to forbidden food could elicit disinhibitive cognitions, which leads to overconsumption (Federoff, Poliwy \& Herman, 1997). This could explain why restrained eaters overeat after exposure to the smeil and sight of forbidden food, without actually eating it and transgressing the diet boundary (Jansen \& van den Hout, 1991). Finally, in order to keep the diet boundary, restrained eaters must actively regulate their eating behaviour, which costs cognitive effort. When they are distracted or involved in a difficult task, the active inhibition of eating behaviour is disturbed, causing the restrained eaters to eat more. Manipulating the cognitive load of restrained and unrestrained eaters while they are given the opportunity to eat, some researchers found increased food intake in restrained eaters during high cognitive load (Ward \& Mann, 2000), whereas others found no effect (Boon, Stroebe, Schut \& Jansen, 1997).

In conclusion, the boundary model of binge eating initiated an enormous amount of research. The model states that restrained eaters have a diet boundary. When this boundary is transgressed by eating a preload, or, in the extended version, is made ineffective by strong emotions or distraction, disinhibitive cognitions are activated and lead to disinhibition of eating behaviour or binge eating. Experiments using the preload paradigm demonstrated that several factors can trigger overeating or binge eating, like eating a preload or merely see and smell a preload, inducing negative emotions, and both focusing attention towards the preload and distracting the subjects with a difficult task. However, there is no direct support for the intervening role of disinhibitive cognitions or the existence of a diet boundary. Therefore, the exact mechanism how these triggers lead to binge eating is not clear yet.

\section{Conditioning model of binge eating}

A mechanism that might explain why people binge eat is the role of conditioning processes and this provides a modell how certain triggers can lead to binge eating. This model originated in the addiction field. There are important resembles between binge eating and addictive behaviour. Craving for and preoccupation with a substance (drug or food) characterise both and there is a loss of control during intake. These similarities gave rise to the idea the same mechanism is responsible for the craving and the uncontrolled intake in drug addicts and binge eaters. The model states that conditioned processes play a part in craving for the drug and relapse after a period of abstinence. When someone uses drug, this has a profound effect on both physical and 
emotional processes. When someone develops a drug habit, in which the same cues are always present during or right before drug use (for example, environment, the sight and smell of the drug itself, drug taking rituals, emotional state), these cues can become conditioned stimuli and predict the drug response. Exposure to these cues then, evokes responses on their own, which are called conditioned responses or cue reactivity. This reactivity is experienced as craving and leads to drug taking behaviour. There is considerable support for the idea that conditioned processes play a part in addictive behaviour. Numerous studies found autonomic responding in addicts when exposed to drug-related cues (Childress, Ehrman, Rohsenow, Robbins \& O'Brien, 1992; Tiffany, 1995) and cue reactivity has been found to be predictive of relapse of drug use (Childress et al., 1992, Cooney, Litt, Morse, Bauer \& Gaupp, 1997; Laberg; 1990; Niaura et al., 1988; Rohsenow et al., 1991, 1994). The function of the conditioned reactivity is not clear yet, it is thought to resemble withdrawal symptoms (Wikler, 1980), prepare the body for the effects of the drug (Siegel, 1989) or reflect motivational responses (Stewart, de Wit \& Eikelboom, 1984).

Applying this model to binge eating, an eating binge has a profound effect on both physical and emotional processes. When someone regularly has eating binges, and these binges are reliable preceded by specific cues (like emotions, being home alone, time of day or the sight and smell of food), these cues become predictors of a binge. Exposure to these cues will evoke conditioned responses, which are supposed to be experienced as an irresistible craving for food and thus make a binge almost inevitable (Jansen, 1998b). For example, consider the typical eating binge of the bulimic patient, described in the beginning of this chapter. This patient always binges when she is alone; she puts on special clothes, arranges the food on a tray, sits down on the couch and selects a magazine. All these actions and objects predict an eating binge. The body reacts to this by preparing for the enormous amount of food that is expected. These physiological changes are felt as craving for food and an eating binge becomes almost inevitable.

Three important assumptions are made in this model. First, when cues are linked repeatedly to eating binges, these cues become conditioned stimuli and evoke conditioned responses. Second, these conditioned responses are experienced as craving for food and third, the increase in physiological responses and craving leads to binge eating.

Before looking at the evidence for these three assumptions, it is important to know what kind of conditioned responses can be expected. Therefore, the unconditioned responses to food intake must be examined. The physiological responses of food intake are thoroughly investigated and a broad range of responses is found. For example, during a meal increases are found in heart rate (Vaz et al., 1995), temperature (Dauncy, Haseler, Thomas \& Parr, 1983; Hirai, Tanabe \& Shido, 1991) and gastric activity (Stern, Crawford, Stewart, Vasey \& Koch, 1989). Also, a meal generally increases blood sugar levels, which elicit the secretion of insulin (Woods, 1991). Although the physiological effects of an eating binge have not been reported yet, they can be expected to be more profound. The emotional effects of an eating binge are also documented: bulimic women reported lower mood, disgust or guilt after a binge (APA, 1994; Waters et al., 2001). In sum, a wide range of responses can be evoked during exposure to conditioned cues. 
A second important issue is what kind of cues can be expected to serve as conditioned stimuli? Several triggers for binge eating are identified, like negative emotions (Cooper and Bowskill, 1986; Meyer, Waller \& Waters, 1998; Polivy \& Herman, 1993), being alone or time of day (Waters et al. 2000), and tasting, seeing or smelling the craved food (Federoff et al., 1997; Jansen \& van den Hout, 1991). Of some of these triggers, it is well documented that they can elicit conditioned reactivity. When nomal subjects are exposed to sensory properties of food (e.g. sight, smell and taste) or simply the thought of eating, physiological responses are elicited, named cephalic phase responses. These responses are the direct result of sensory stimulation, but conditioned processes also play a role (Mattes, 1997). For example, it has been found that exposure to food increases salivation (Epstein, Paluch, Smith, \& Sayette, 1997; Wooley \& Wooley, 1973), gastric activity (Stern ef al., 1989), insulin rellease (Teff \& Engelman, 1996, Secchi et al., 1995) and temperature (Woods \& Strubbe, $1994)$.

Let's go back to the assumptions of the conditioning model of binge eating. Besides the role of cephalic phase responses in normal eating behaviour, there is evidence for the first assumption of the conditioning model of binge eating: subjects with eating disorders have increased cue reactivity.

\section{Conditioned ches evoke conditioned responses.}

An overview of studies on food cue reactivity in subjects with eating disorders is given in Table 1. Broberg and Bemstein (1989) found no difference in plasma glucose and insulin and subjective scores of hunger and palatability between bulimic women and chronic dieters as response on a cinnamon roll. Bulik, Lawson and Carter (1996) found that bulimic women had a lower salivary response, a larger urge to binge and higher anxiety scores on individualised binge food than both restrained and unrestrained women. Carter, Bulik, Mclntosh and Joyce (2001) found that bulimic women had a higher heart rate and lower salivary responses to individualised binge food before compared to after treatment. No difference was found on systolic and diastolic blood pressure. Johnson, Jarell, Chupurdia and Williamson (1994) found no difference between bulinic women and controls on heart rate, plasma glucose and insulin on exposure to imagery food and chocolate chip cookies and milk. Karhunen, Lappalainen, Tammela, Turpeien and Uusitupa (1997) compared responses of obese binge eaters to obese non-binge eaters on a typical Finnish breakfast and found no difference on plasma insulin, glucose and free fatry acids. However, the binge eaters salivated less than the control group. The binge eaters also reported more desire to binge, no differences on hunger were found. Klajner, Heman, Polivy and Chhabra (1981) exposed restrained women, obese restrained women and controls to hot slices of pizza. Both restrained groups salivated more than the control group. No group effects on ratings of hunger and liking of the food were found In a second experiment, restrained, unrestrained, obese and obese restrained women were exposed to chocolate chip cookies; their reactions were compared to the same cookies, died green. Both restrained groups salivated more than the unrestrained groups, again no differences were found on ratings of hunger or liking of the food. LeGoff, Leichner and Spigelman (1988) exposed anorectic, bulimic and unrestrained women to the odour of several food items and non-food items as control exposure. The bulimic women salivated 
more than the control women; the anorectic women salivated less than the controls. The anorectic women reported less hunger than the control women did, no effects on anxiety scores were found. The same women were exposed to the same items again after treatment. This time, no differences between the groups were found. Overdwin, Jansen and Eilkes (1997) exposed restrained and unrestrained women to slides of preferred food. Compared to neutral slides. No differences between groups were found on skin conductance, heart rate, startle reflexes and ratings of craving. However, the restrained women showed more activity in facial EMG than unrestrained women. Piacentine, Schell and Vanderweele (1993) exposed restrained and unrestrained women, who were fasting or non-fasting, to pleasant and unpleasant food odours. The restrained women showed lower skin conductance than the unrestrained women did. No differences on hunger ratings were found. Staiger, Dawe and McCarthy (2000) compared bulimic women to a control group. Both groups were exposed to individualised binge food or a letuce leaf as control stimulus. No differences on salivation were found. Subjective ratings revealed that the bulimic women felt a greater urge to binge, were nore stressed and felt less in control. Ratings on confidence to resist a binge or happiness were equal between the groups. Teff and Engelman (1996) let normal women, ranging from high to low restrained, sham eating personal palatable food. Restraintness was significantly correlated to plasma insulin. No results on plasma glucose were found. Tepper (1992) exposed restrained and unrestrained women to a hot slice of pizza. The restrained women salivated more. Tuomisto et al., (1999) exposed chocolate addicts and controls to pictures of chocolate, real chocolate and the taste of chocolate. No differences on heart rate were found, but the chocolate addicts salivated more than the control women did. Of several subjective ratings, the addicts reported more craving and desire to eat, more anxiety, depression, frustration, guilt and excitement and less calmness. No effects were found on hunger, fullness, relaxation and contentment. In a second study, again chocolate addicts and controls were exposed to pictures of chocolate and real chocolate, while the same variables were measured. This time, no physiological differences between the groups were found. The subjective responses were alike the first study, besides that in addition the chocolate addicts reported less fullness this lime. Vogele and Florin (1997) exposed binge eating and control women to individualised food items. They found that the binge eaters had higher systolic blood pressure and skin conductance level than the control group. Diastolic blood pressure, heart rate and respiration rate did not differentiate between groups. Also no differences between groups on hunger", desire to binge, sadness and nervousness were found. Wilson and Mercer (1990) exposed nomal women, ranging from high to low restrained, to chocolate chip cookies. Restraintness correlated to significant to skin conductance. Finally, Wooley and Wooley (1981) exposed restrained and unrestrained women to palatable food and non-food. The restrained women salivated less than the control group.

The outcomes of these studies are mositly inconsistent, however, it is difficult to compare these studies because different kinds of abnormal eating behaviour, cues and physiological parameters are used. A commonly used parameter is salivation. Five studies found a greater salivary response in eating disordered subjects to a food cue, four studies found a smaller salivary response and three studies found no difference. With skin conductance, two studies found a greater response in eating disordered 
subjects to food cues, one study found a smaller response and one study found no difference. Subjective ratings of craving or related items (e.g. urge to binge) are also frequently measured. Of eight experiments, six reported an enlarged increase of craving in eating disordered subjects, compared to control subjects, whereas two studies reported no differences between groups. In conclusion, robust effects of exposure on subjective measures like craving are found. In general, altered food cue reactivity is found on physiological measures, however, the size and direction is different in several studies. This outcome resembles results in the field of addiction research. Responses of addicts to specific drug cues have been found to be larger and smaller compared to normal control subjects (Niaura et al., 1988). In a meta-analysis, Carter and Tiffany (1999) found large effect sizes of cue exposure on ratings of craving for the drug. Smaller but significant effect sizes are found for physiological responses, for example an increase in heart rate, sweat gland activity and a decrease in skin temperature. For a meta-anallysis of cue reactivity in binge eaters, more experiments are needed. Also, research into the role of the cue that is used, temporal effects and response domains might give more insight in the size and direction of cue reactivity. Although no final conclusions can be drawn yet, there is strong support for subjective cue reactivity in eating disordered subjects and, although less robust, for altered physiological cue reactivity. 


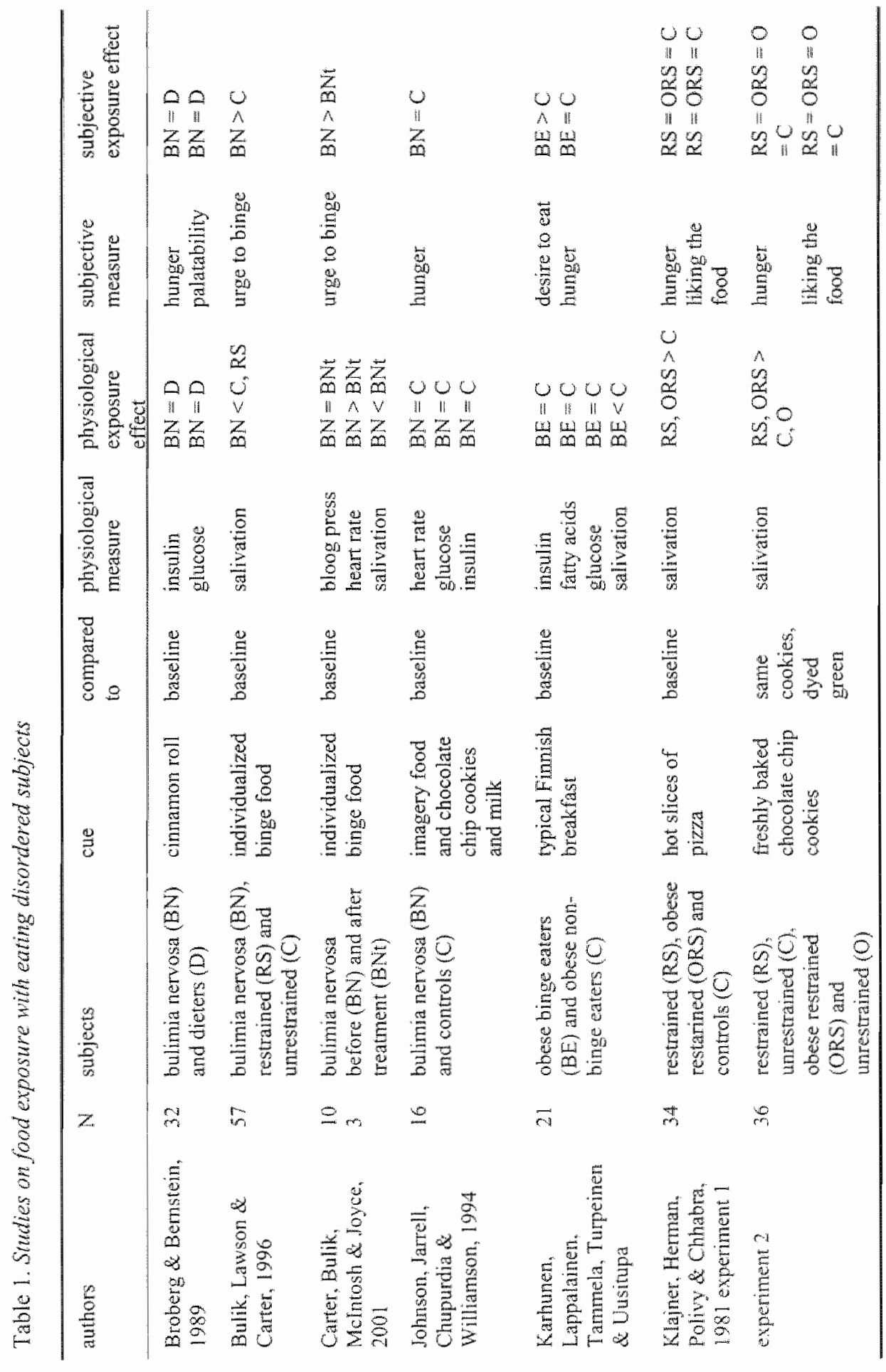


Chapter !

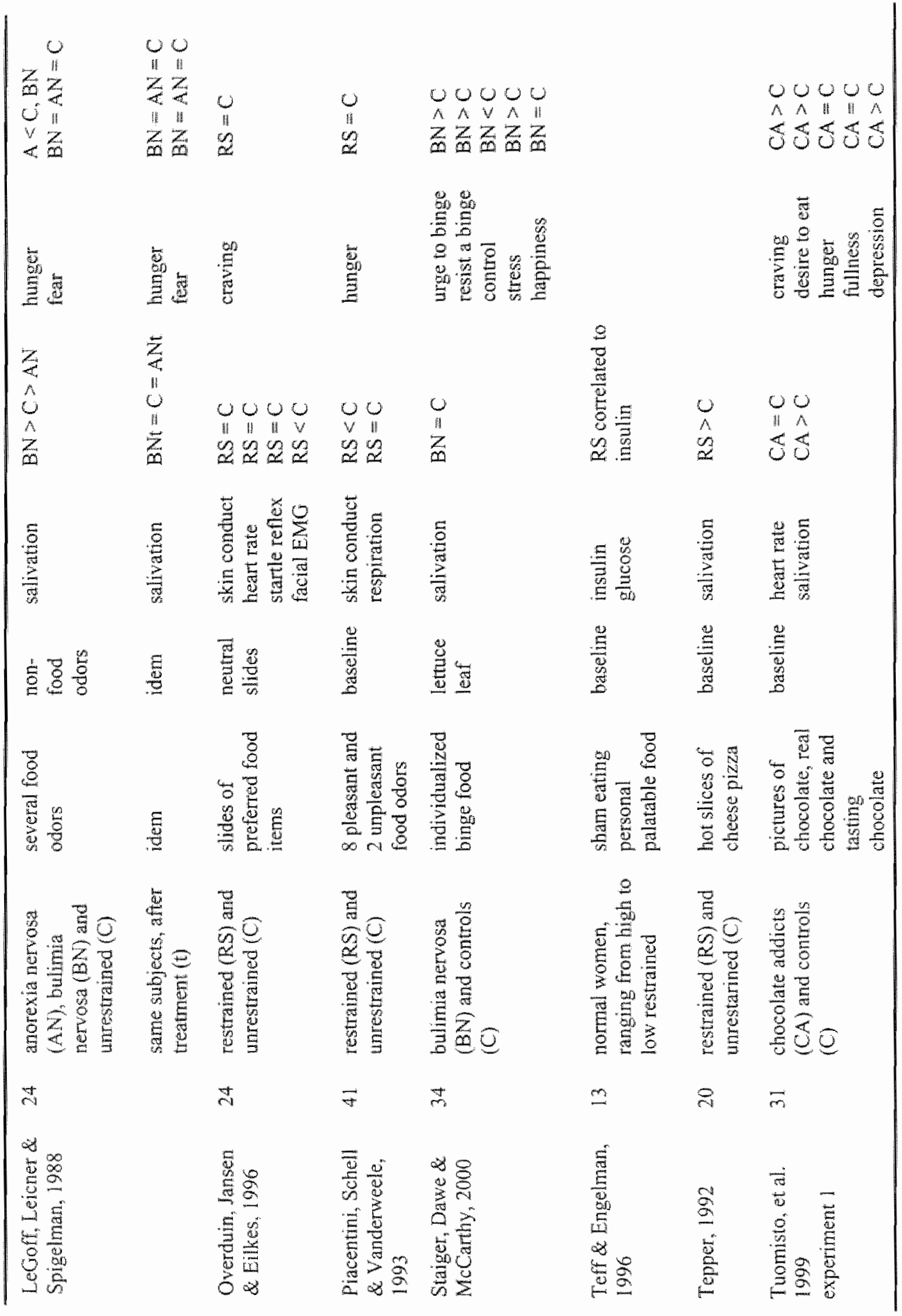


0000000
$A$

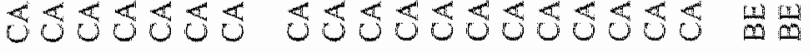

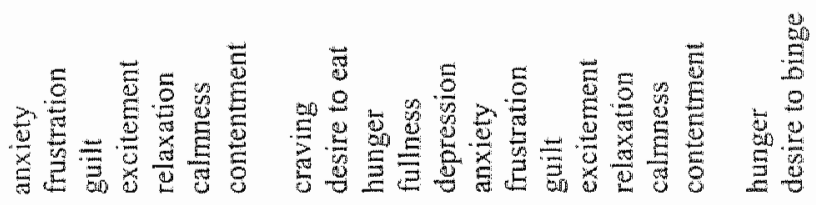

40

$\frac{9}{5}$

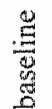

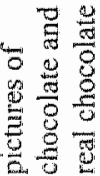

$\stackrel{\frac{3}{0}}{\frac{3}{3}}$

它

$8 \frac{2}{8} 0$

8

$\frac{\sqrt[2]{0}}{\frac{3}{0}}$

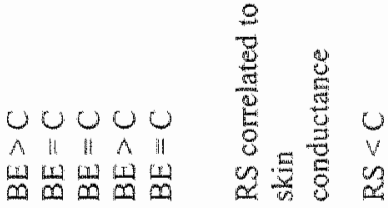

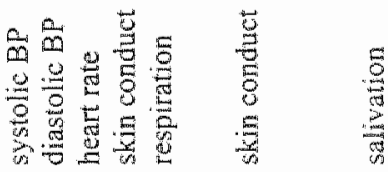

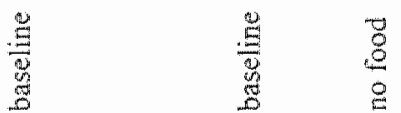
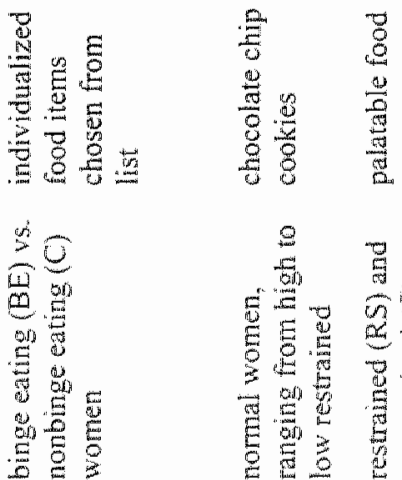

8

$\frac{E}{5}$
0
$z$
0
0
0
0

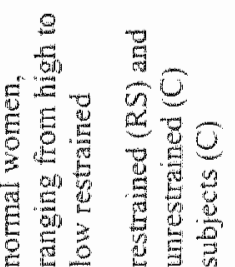

9

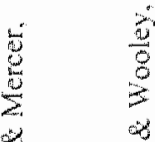

$\frac{2}{8} \quad 2$ 


\section{Cue reactivity is experienced as craving.}

The second assumption has also received some support. For example, when insulin levels are artificially influenced, subjects rated the highest hunger scores during the highest insulin levels (Rodin, 1985). As mentioned above, a rather robust effect of cue exposure on ratings of craving and urge to binge are found in eating disordered subjects. However, more research is needed to clarify the contribution of physiological responses to feelings of craving for food.

\section{Increases in physiological responses and craving lead to binge eating.}

This third assumption was confirmed in a few studies. In rats it is found that prior to a spontaneous meal the blood glucose begins to drop (Woods \& Strubbe, 1994). In bulimic women, urge to binge as response to food exposure after treatment did predict poor outcome after $\mathbb{y}$ year, suggesting that craving for food during exposure predicts relapse in binge eating (Bulik, Sullivan, Joyce, Carter \& McIntosh, 1998). Diary reports also stress the importance of craving in eating binges (Waters et al, 2000; 2001). Again, additional research at the relation between cue reactivity, craving and binge eating is needed.

The cue reactivity theory has clear therapeutic implications: the conditioned bond between the cues and the reactivity should be broken. When a cue does not predict an eating binge anymore, reactivity nor craving will be elicited and the patient stops bingeing. In order to establish this, patients can be exposed to binge cues, while preventing them from binge eating. Also, they can eat binge food in a totally different context. In this way, binge cues do not predict an eating binge anymore and cue reactivity and craving will extinct. Although the therapy is rather new, up to now research has shown that this therapy is effective in diminishing the number of eating binges. It also has a profound effect on self-esteem, mood and dysfunctional thinking patterns (Hansen \& de Haan, 1995; Jansen et al., 1989; Jansen, Broekmate \& Heymans, 1992; Jansen, 2001; Schmidt \& Marks, 1988).

In summary, the conditioned model of binge eating is founded on three important assumptions. First, when cues are reliable predictors of eating binges, exposure to these cues evoke conditioned physiological reactivity. Second, this reactivity is experienced as craving for food and third, physiological reactivity and craving provokes binge eating. The evidence provided in the literature for these assumptions is not conclusive. Inconsistent outcome while using different methodologies makes it difficult to draw conclusions about the usefulness of the cue reactivity theory. Because the conditioning model can play an important role in explaining the mechanisms underlying binge eating and might provide new therapy methods for eating disorders, it remains worth the effort to aim research at this model and its assumptions. 


\section{Hypotheses and research goals}

In this thesis, the conditioning model of binge eating will be imvestigated. First, in the method section, techniques for measuring salivary responses to food cues will be tested (chaper 2 and 3). Salivation is a frequently measured response in cue reactivity paradigm and altered salivary responses are often found. However, the most frequently used method for measuring saliva has some disadvantages and more advanced methods might give clearer insight.

In the second part, the assumptions of the conditioning model of binge eating will be tested. Three studies are performed, respectively with nomal subjects, restrained eaters, who serve as a model for binge eaters, and clinical binge eaters. In the study with normal subjects (chapter 4), cephalic phase responses and the relation with unconditioned responses to food intake will be investigated. The second assumption of the model, physiological reactivity is related to craving for food and the third assumption, physiological reactivity and craving is related to food intake, will be tested in normal subjects. For these reasons, normal subjects are exposed to palatable food and after the exposure they are instructed to eat a large amount of food, in order to imitate an eating binge. During the exposure, the meal and after the meal, physiological and subjective reactivity is measured. Relationships between the physiological measurements, subjective states, caloric intake and overeating tendency will be examined.

In the study with restrained eaters (chapter 5), both restrained and unrestrained eaters are exposed to either food or soap. Afterwards, they perform a taste test. It is hypothesised that restrained eaters show larger cue reactivity during exposure to food (first assumption), report more craving (second assumption) and eat more during the taste test (third assumption).

In the last study, patients with bulimia nervosa and control subjects are exposed to personal binge food (chapter 6). Physiological and subjective reactivity is measured. Afterwards, the subjects perform a taste test. It is hypothesised that the bulimic women show larger cue reactivity (first assumption) and report more craving during food exposure (second assumption) and that this reactivity is positively related to food intake during the taste test (third assumption).

In the final chapter, a conclusion about the role of conditioned processes in binge eating will be drawn. Possible implications for therapy methods and further research will be discussed. 
Methods for measuring the saliva response 


\section{Recording of swallowing events using electromyography as a non-invasive measurement of saliva ${ }^{1}$}

\section{Abstract}

The present study examined whether the measurement of swallow activity by electromyography (EMG) provides a sensitive and valid method for the assessment of the amount of saliva secreted. Thirteen subjects tasted temon juice and water, and smelled lasagne and hay, while the amount of saliva, measured with the aid of cotton dental rolls, was compared with the number of peaks in the EMG activity of the musculus digasticus. Swallowing indeed differentiated between the stimuli and the correlation between the numbers of swallows and the amount of saliva was significant. The present data suggest that monitoring the swallowing movement using EMG might be a sensitive, valid and reliable method for the measurement of salivary flow. The use is recommended for the measurement of saliva when a simple and non-invasive method is needed.

\footnotetext{
'Nederkoorn, C. Smulders, F.T.Y., \& Jansen, A. (1999). Recording of swallowing events using electomyography as a non-invasive measurement of salivition. Appetite, 33, 361-369.
} 


\section{Introduction}

One of the main functions of saliwa is to act as a lubricant, facilitating passage through the digestive tract; it also initiates digestive processes. Chemosensory stimulation (e.g. smell and taste) and the view of food are able to elicit an increase in salivary flow (Epstein, Paluch, \& Coleman, 1996; Wooley, Wooley, \& Dunham, 1976) which optimises the digestion, absorption and use of digested nutrients (Mattes, 1997). The anticipative salivary reaction to food cues is stronger when the subject is hungry or when the food is palatable (Franchina \& Slank, 1988; Hodgson \& Greene, 1980; Wooley \& Wooley, 1973. 1981; Wooley et al., 1976; Wooley, Wooley \& Williams, 1975). Obesity, dieting and eating disorders also influence saliva responses to food cues (Epstein et al., 1996; Klajner, Herman, Polivy \& Chhabra, 1981; LeGoff, Leichner and Spigelman, 1988; Wooley et al. 1976). For example, LeGoff et al. (1988) found that subjects with anorexia nervosa salivated less and subjects with bulimia nervosa salivated more when exposed to different food odours, compared to matched controls. Measurement of salivary responses might therefore be an important tool for the investigation of eating behaviours. In other research areas too, the measurement of salivary responses has been valuable. In the field of alcohol addiction, for example, the salivary response on alcohol cues has often been used as an index of craving or cue reactivity (Cooney, Baker, Pomerleau \& Josephy, 1984; Pomerleau, Fertig, Baker \& Cooney, 1983; Walitzer \& Sher, 1990).

There are several techniques for the measurement of saliva. Some are not suitable in experiments on eating behaviour or craving for drugs because of their invasive characteristics. For example, measurement by the insertion of a cannula into the various ducts of the salivary glands is laborious and painful (Gormezano, 1966; White, 1977). Measurement with Lashley's disk may also cause discomfort (Gomezano, 1966) and does not tap all sources of saliva. Moreover, it is unpleasant for subjects to void saliva; the method does not allow online monitoring and thus requires intertuption of the experiment. A most ideal technique is non-invasive, does not interfere with appetite or craving for drugs, permits study of the change in salivary llow over time and minimises the influence of demand characteristics and expectancies, which are also found to influence the salivary response (Siegel \& Hagen, 1982). It will therefore be a great advantage when the subject is not aware of the measurement of their salivation.

An easy and frequently used method is the absorption of saliva by rolls of cotton. According to the Strongin, Hinsie and Peck (SHP) technique (in White, 1977), two rolls are placed buccally and one sublingually. The weight of the rolls is determined before and after the period of measurement. The cotton roll method has proven to be a reliable, valid and sensitive technique: White (1977) showed that measurements with cotton rolls comrelated strongly with Lashley's disks measurements. Others were able to distinguish adequately salivary responses to diverse stimuli (Drummond, 1995; Epstein, Rodefer, Wisniewski \& Caggiula, 1992; Epstein, Wisniewski, Deflavia \& Mitchell, 1995; LeGroff et al., 1988; Pomerleau et al., 1983; White, 1977). However, the dental roll method also has disadvantages: the monitoring of changes in salivary flow over time courses shorter than 2 mimutes is less 
sensitive (Epstein et al., 1995) and in order to insert and remove the dental rolls, it is always necessary to interrupt the experimental procedure. Furthermore, it is rather umpleasant to keep dental rolls in one's mouth and this might interference with appetite. Finally, the pressure of the dental rolls on the salivary glands can itself provoke a salivary response, thus affecting the reliability of the experimental data.

A completely different technique is to measure the frequency of swallows as an estimate of amount of saliva. The frequency of swallowing can be determined by counting peaks of electromyographic activity of the musculus digastricus. The swallow technique allows monitoring time effects and is not invasive or reactive. Kapila, Dodds, Helm \& Hogan (1984) found that the rate of spontaneous swallows appeared to be influenced directly by salivary flow. They showed that surface electrodes placed on the larynx could measure swallow activity adequately when the subjects did mot move their mouth or jaws. Consequently, the method cannot be used during the act of eating. However, both alcoholics and controls were found to swallow more during exposure to their favourite alcohol beverage then to cedar chips (Kaplan et al., 1985) and alcoholics swallowed more often than non-alcoholics in response to their favourite alcohol beverage relative to a control stimulus (Ponerleau et al., 1983). In a validation study (Pomerleau et al., 1983) the change in swallowing and the change in saliva measured with dental rolls were significantly correlated $\left(r^{*}=0.69\right)$. Unfortunately, this was the only study in which swallowing was compared with another method to measure saliva and no details are given about the method of measurement. Furthermore, only alcoholics were included, who were exposed to their favourite beverage to provoke saliva.

Because of the obvious advantages of the swallowing technique over others, it is worthwhile to examine its validity and sensitivity in a sample of normal subjects, utilising various food and other cues. In the present study, two saliva-provoking stimuli (lemon juice and lasagne) and two control stimuli (water and hay) were presented. If the swallowing method is sensitive, it should be able to discriminate between these stimuli. The correlation with the dental roll technique was used as an index of criterion-validity, whereas the correlation between repeated measurements was used to examine the reliability of the new method.

\section{Method}

\section{Participants}

Sixteen women participated in the experiment. Only dictary unrestrained women were invited to participate, because dieting and eating disorders might influence salivary responses (LeGoff et al., 1988). The subjects were instructed not to eat or to drink coffee in the $4 \mathrm{~h}$ before the experiment. All subjects liad a nomal weight (mean Body Mass Index (BMI, weight $(\mathrm{kg}) /$ length $\left.^{2}(\mathrm{~m})\right)=21.9$, Standard Error of Mean $(\mathrm{SEM})=0.4$ ) and mean age was 20.7 (range 19-24). None of the subjects reported 
having a cold or having trouble with smelling the stimuli. No one suffered from hay fever or used any medication known to infuence saliva production.

\section{Questionnaires}

As part of another study, all first grade students of the department of psychology of the Maastricht University completed a set of questionnaires, one of which was a Dutch translation of the Restraint Scale (RS; Herman \& Polivy, 1980). The RS is a self-report questionnaire consisting of 10 items assessing attudes towards weight and eating, degree and frequency of dieting, and weight fluctuations. The RS is reliable and valid in nomal-weight samples, its test-retest reliability is high and the internal consistency is good (Cronbach's alpha $=0.86$; see Rudeman and Besbeas, 1992). The scale has high predictive validity; it is a good predictor of eating behavior in normal-weight individuals in a variety of situations (Gorman and Allison, 1995; Heatherton, Herman, Polivy, King and McGree, 1988). Subjects with scores lower then 12 were considered unrestrained (based on the mean score of 269 Dutch female students; Overduin \& Jansen, 1996a), and they were invited to participate. In addition, line ratings were used to rate hunger, ranging from 0 (not hungry at all) to 100 (very hungry), and liking for lasagne $(0=$ not at all, $100=$ very much). Finally, a questionnaire enquired about compliance with the instructions, ability to smell and use of medication.

\section{Stimuli}

The experimental gustatory stimulus was $0.3 \mathrm{mll}$ lemon juice, administered by drops on the middle of the tongue. Its control stimulus was $0.3 \mathrm{ml}$ mineral non-carbonated water, also administered in drops. The lemon juice and mineral water were both at room temperature. The experimental olfactory stimulus was the sight and smell of a plate with $500 \mathrm{~g}$ lasagne, heated in a microwave. Its control stimulus was a plate with hay on it.

\section{Measures}

Three dental rolls were used (Hartman nr. $2,10 \times 35 \mathrm{~mm}$ ), one placed sublingually and two placed buccally. The weight of the three dental rolls in a little plastic bag was determined before the experiment. At the end of each measurement episode, the subjects were instructed to take the rolls carefully with their fingertips and to put them back in the plaslic bag as quick as possible. Then they sealed the bag. The weight was determined again after the experiment and the gain in weight was calculated. Maximum absorption possible with the three dental rolls was approximately $10 \mathrm{~g}$. The maximum weight measured in this experiment was $8.45 \mathrm{~g}$; therefore complete Saturation was not reached. 
Swallowing was measured by Ag-AgCl electrodes (diameter II mm, SensorMedics). Two electrodes were attached under the left jaw, lengthways along the anterior part of the musculus digastricus, at a distance of $1-1.5 \mathrm{~cm}$ from each other, and a reference electrode was placed on the left mastoid process. EMG activity was recorded using a Psylab Bio-Amplifier, with a band pass filter set between 10 and 300 Hz. The sigmal was online rectified and integrated (using Psylab Rectifier/Integrator) with time constant set at $200 \mathrm{~ms}$ and digitised ( $12 \mathrm{bit}, 500 \mathrm{~Hz}$ ) on a personal computer. EMG was recorded for two minutes after each stimulus. The integrated EMG data was further used for analysis. First, the data was resampled at $20 \mathrm{~Hz}$ by replacing every 25 samples by the mean value of these samples, in order to reduce the number of data points. The epochs were then lowpass filtered at $.036 \mathrm{~Hz}(-3 \mathrm{~dB}$, Ruchkin \& Glaser, 1976), and the mean level of an epoch was subtracted as baseline. An example of a swallow, before and after" these transformations, is depicted in Figure 1. From this smoothed signal, the computer detected every pak (defined as a sample flanked by samples with lower values). Close visual inspection of pilot swallow measurements led to the definition of a swallowing response being a response of the integrated signal above the threshold of $3.8 \mathrm{uV}$, with a minimum of 1.5 seconds between responses. During the recordings, artefacts like coughing were noted down by the experimenter. Epochs with artefacts were not analysed. All signals were also visually exmined, and the first author counted the number of apparent swallows, after the removal of any cues that indicated the experimental conditions. The correlation between visual and automatic analyses of swallowing was significant over all (104) records $(r=90, p<$ $.001)$. The results yielded by the automatic detection were used for further processing.

\section{Procedure}

After the subject entered the laboratory, the electrodes were attached and the signal was checked. Then the subject was instructed to rate her hunger and to practice with the insertion and removal of the dental rolls, including putting them back in the plastic bag and sealing it. The subject was asked to sit quietly and to relax during the measurements, without tallking or moving, in order to diminish novement artefacts. A baseline EMG record of 4 minutes was made during which saliva was simultaneously measured with the dental roll method. Then the subject received each stimulus in turn, together with new dental. rolls. She was instructed to concentrate on the taste or the smell of the stimuli. The order of presentation of the two pairs of stimuli was counterbalanced. After each recording the subject rinsed her mouth with $30 \mathrm{ml}$ mineral water followed by a two minutes pause.

Because dental rolls absorb saliva, their presence might diminish the swallow frequency. The pressure of the rolls on the cheeks is also able to influence salliva production. Therefore, the whole procedure was repeated without dental rolls inserted. The order of measurement with and without dental rolls was counterbalanced. At the end of the experiment, the subject filled in the questionnaires; her weight and height were measured and she received payment. 
(a)
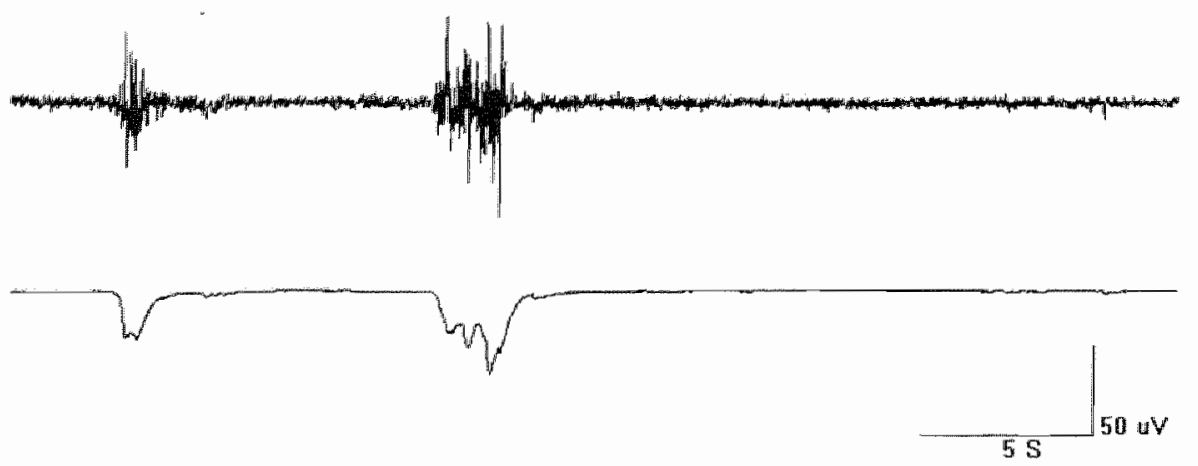

(b)

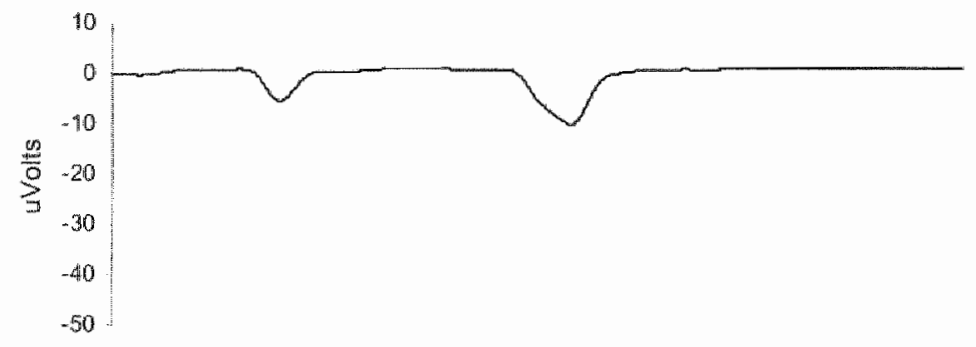

Figure 1. Example of two swallows, in epoch of 30 s. (a) Upper line is raw EMG, botton line rectified and integrated EMG: (b) depicts signal after resampling, filtering and baseline subtraction. Both peaks are larger then the threshold and identified as swallows.

\section{Results}

\section{Subject characteristics}

All subjects but one reported that they complied with the instructions neither to eat nor to drink coffee for $4 \mathrm{~h}$ before the experiment. The data of this one subject were excluded from analysis. Two subjects reported to have a strong dislike for lasagne (scores 24 and 38) and they did not sit quietly while smelling the lasagne. Their data were also excluded from analysis. The remaining subjects $(n=13$, mean BMI $=21.6$, 
$\mathrm{SEM}=0.39 ;$ mean age $=21, \mathrm{SEM}=0.41$ ) reported to like lasagne (mean $=77.8, \mathrm{SEM}$ $=4$ ) and were moderately hungry (mean VAS score $=55.4, \mathrm{SEM}=5.5$ ). The Restraint Score of these 13 subjects was $7.7(\mathrm{SEM}=0.7)$.
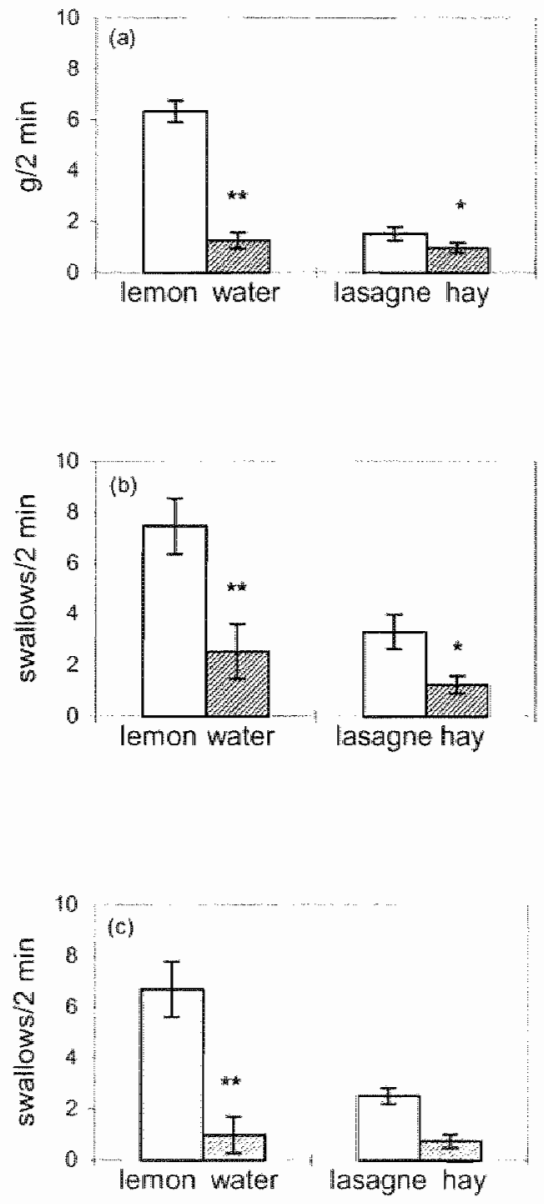

Figure 2. Reactions to the different stimuli, measured by (a) dental rolls, (b) swallowing without dental rolls and (c) swallowing with dental rolls. with the standard error of means (SEMS). * $p<0.05, * * p<001$. 
Dental rolls

Subjects salivated significantly more when tasting lemon juice than when tasting water (Fig. 2), $t(12)=14.7, p<.001$. The subjects also salivated more when they were exposed to lasagna than when they were exposed to hay, $t(12)=2.3, p<.05$.

\section{Swallowing}

Subjects swallowed significantly more after tasting lemon juice than after tasting water, $F(1,12)=50.1, p<0.001$ (Fig.2). Insertion of dental rolls had no significant effect on the number of swallows during the gustatory stimuli and there was no significant interaction effect. However, during the exposure to the olfactory stimuli subjects swallowed less when the dental rolls were inserted $F(1,12)=6.9, p<0.05$. There was also a significant interaction effect: the difference between lasagna and hay was larger without than with dental rolls present, $F(1,12)=12.1, p<0.005$. Post hoc ttests revealed that the difference in swallows to lasagna compared to hay is significant in the absence of dental rolls, $t(12)=3.1, p<0.05$, but it is not when dental rolls are inserted, $t(12)=0.64$. Generalising over all stimuli, subjects swallowed more in the absence of dental rolls than in their presence, $r(51)=2.4, p<0.05$.

\section{Correlation of measurements}

To validate the use of swallows as an index of saliva, the correlation with weight in saliva collected in dental rolls was calculated. Data for all four stimuli were included in the correlation $(\mathrm{n}=13$ subjects $\times 4$ stimuli $=52$ ). Weight gain of dental rolls correlated with number of swallows in absence of dental rolls, $r=0.57, p<0.001$, and with number of swallows with dental rolls inserted was $0.72, p<0.001$ (Fig. 3).

For the experimental study of influences on eating behavior, changes in saliva flow need to be measured. Therefore, the change in saliva response to control and experimental stimuli (measured with dental rolls) was correlated with the change in the number of swallows between the control and experimental conditions, subtracting effects of the control stimuli from the effects of the experimental stimuli, as in Pomerleau ef al. (1983). In the lemon juice minus water condition, the change in salivation measured by dental rolls did not correlate significantly with the change in the number of swallows $(r=0.19$ without dental rolls, $r=0.23$ with dental rolls). In the lasagna minus hay condition, however, the change in saliva measured with dental rolls correlated significantly with the change in number of swallows, both without dental rolls $(r=0.85, p<0.01)$, and with dental rolls $(r=0.65, p<0.05)$, see Fig. 4 . 
(a)

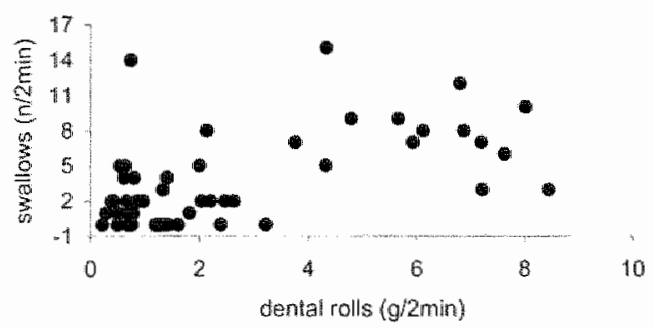

(b)

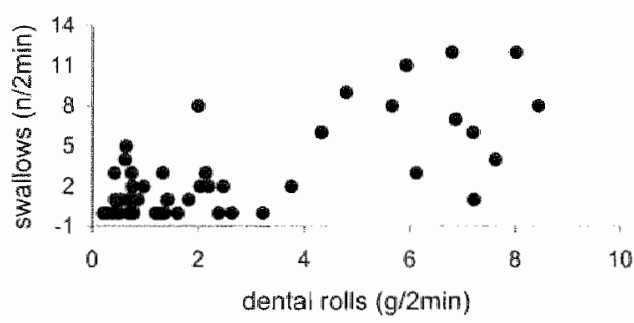

Figure 3. Correlation between increase in weigh" of dental rolls and number of swallows", measured mithout (a) and with dental rolls inserted (b). as response to fou" differen stimuli.

The test-retest reliability was determined by computing the correlation between measurements of the number of swallows with and without dental rolls inserted, including all the stimuli $(\mathrm{N}=52)$. This correlation was highly significant $(r=0.74, p<$ $0.001, \mathrm{n}=52$ ). Test-retest reliability calculated over each stimulus separately yiclded the same results. 
(b)

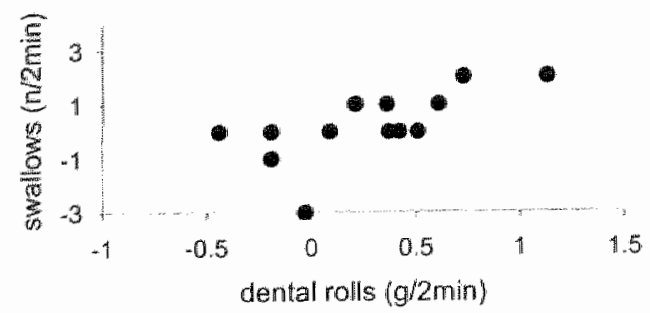

(b)

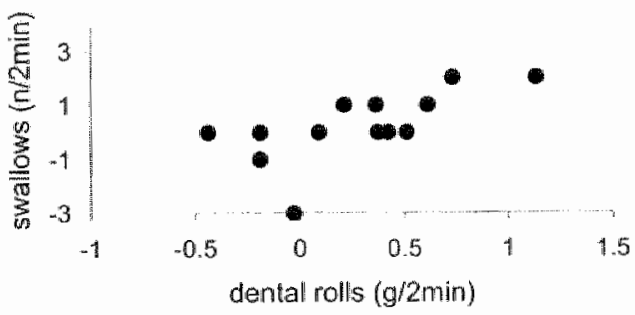

Figure 4. Correlation between increase in weight of dental rolls and number of swallows, measured withou (a) and wh denal rolls inserted (b) as response to lasagne minus hay.

\section{Discussion}

These results indicate that electrophysiological measurement of swallowing is a sensitive, valid and reliable index of the amount of saliva produced in response to food stimuli. Swallowing occurred more often during the taste of lenon juice than it did with water, in both the absence and the presence of dental rolls. Without dental rolls, the subjects swallowed more during the exposure to lasagna than they did to hay, although this effect disappeared in the presence of dental rolls. The measurement of swallowing is thus a sensitive method, especially when no dental rolls are inserted. Test-retest correlation shows that the method is also reliable. 
Correlation between the number of swallows and the amount of saliva over all stimuli showed that the elctromyographic method is valid. A closer look at the data, however, shows that the correlation using the lasagna minus laay value is significant wheras it is not with the lemon juice minus water value. This may be because lemon juice is such a strong stimulus that it provokes contractions of muscles in and near the mouth, which are unrelated to swallowing. So, electronyography may be most useful for research into foods and drinks, which do not elicit such contractions.

A limitation to the method is that the validity is diminished in situations where movement artifacts cannot be prevented and during strong stimuli such as extreme sourness. In these instances, other methods (like use of Lashley"s disk) must be considered. In other cases, the electromyographic method has the advantages over cotton rolls that measurements are not invasive, will not provoke salivary reactions on their own, do not interfere with appetite or craving, and enable the study of changes in sallivary flow over time. The method might prove to be useful, therefore in the study of human responses to food (e.g. anticipation, cue reactivity, cue exposure), eating disorders and addictive behavior. 


\section{Experimental comparison of different techniques to measure saliva ${ }^{1}$}

\section{Abstract}

Two methods for measuring the secretion of saliva, use of cotton rolls and counting swallows using electromyography, have proved to be reliable and sensitive, but also have some drawbacks. A third method, electrophysiological measurement of the activity of the parotid gland, has the potential to be a non-invasive index of the production of saliva and may be a valuable supplement to the existing methods. To validate this method, 48 subjects smelled salivaprovoking stimuli, while saliva was measured with all three methods. Results suggest that measurement of activity of the parotid gland is not useful. Both the cotton roll method and counting swallows appeared to be sensitive methods and the data from these methods were significantly inter-correlated. It is recommended that one of these methods be used, dependent on the specific demands of the experiment.

\footnotetext{
'Nederkoom, C, de Wit, T., Smulders, F.T.Y. \& Jansen, A. (in press). Experimental companison of different techniques to measure salliva. Appetite.
} 


\section{Introduction}

The secretion of saliva has digestive functions and is stimulated by (chemo)sensory stimulation of food (Epstein, Paluch, \& Colleman, 1996). The amount of salivation can be an index of various psychological and physiological conditions. For example, hunger, palatability of food, obesity, dieting and eating disorders have been found to influence salivary secretion (Epstein et al., 1996; Klajner, Herman, Polivy \& Chhabra, 1981; LeGoff, Leichner \& Spigelman, 1988). Also emotions like anger and fear can influence salivation. Therefore, measuring the amount of salivary secretion is an important tool in a wide research field.

Several techniques have been developed for the measurement of salivation. An easily and frequently used method is the absorption of saliva by rolls of cotton. The weight of these rolis is determined before and after the period of measurement. This method has proved to be valid, reliable and sensitive (White, 1977). However, some negative aspects can make it less suitable. It is not appetising to keep dental rolls in one's mouth, it is always necessary to interrupt the experimental procedure in order to insert and remove the dental rolls and finally, the pressure of the dental rolls on the salivary glands can provoke a salivary response per se, thus affecting the reliability of the experimental data. Another technique is to measure the frequency of swallows. This can be determined by counting peaks in the electromyographic activity of the musculus digastricus. This technique allows monitoring time effects and is not invasive or reactive, as is the cotton roll method. Experiments show that data collected with this technique correlates well with those obtained by the cotton roll method, provided that certain precautions are taken (Nederkoorn, Smulders \& Jansen, 1999; Pomerleau, Fertig, Baker \& Cooney, 1983). For example, the subject must sit still and be quiet, and prevent jaw movements.

An interesting alternative method might be the electrophysiological measure of the activity of the parotid gland (Davis, Hing \& Co, 1990; Davis, Bauslaugh \& Wintrup, 1996). In this method, an electrode is placed on the cheek, over the parotid gland, and referred to the right mastoid process. In response to lemon juice, a peak in activity has been observed ${ }_{x}$ with a latency of $2.5-3$ seconds, the highest peak around 3.5-7 seconds and recovery between 13 and 25 seconds (Davis et al, 1990). This peak was reliably higher in response to lemon juice, compared to water, and the initial experiments suggested a correlation between the recorded potential and salivary flow. However, lurther validation of the method is lacking. Since this non-invasive method provides a potential index of the production of saliva, it seems worthwhile to test its reliability, validity and sensitivity. This experiment was designed to test the three methods and compare the results. 


\section{Methods}

Forty-eight subjects participated, twenty-four women and twenty-four men. The subjects were instructed not to eat anything or to drink coffee for three hours before the experiment. None of the subjects reported having a cold or any trouble smelling the stimuli. Salivation was measured with three dental rolls, one placed sublingually and two placed buccally. Physiological recordings were sampled at $500 \mathrm{~Hz}$. Swallowing was measured by two Ag-AgCL electrodes, attached under the left jaw, in the length of the anterior part of the musculus digastricus and placed $1-1.5 \mathrm{~cm}$ from each other. A reference electrode was placed on the left mastoid process. Epochs with artefacts like coughing were removed. All signals were visually examined, and after the removal of any cues that indicated the experimental conditions, the first author counted the number of swallows. Parotid activity was measured by two $\mathrm{Ag}-\mathrm{AgCl}$ electrodes, attached over the parotid gland and placed $1-1.5 \mathrm{~cm}$ from each other, and a reference electrode, placed on the right mastoid process. Raw electrophysiological activity was recorded between 0.01 and $10 \mathrm{~Hz}$.

Each measurement lasted 2 minutes and was made twice. First, salivation was measured with dental rolls and second, with the electrophysiological measurements (inn counterbalanced order), because the two types of measurements interfere with each other (Nederkoorn et al., 1999). Between each measurement, the subject received a sip of mineral water and a 2 -minute break. Baseline measurements were made at the beginning and end of the experiment. The subject received successively four different stimuli a freshly cut lemon, chocolate, lasagne heated in a microwave, and chips of wood. Each stimulus was presented on a plate covered with a dish, which was removed at the start of a measurement. The order of the four stimuli was counterbalanced using a Latin square. In total, 12 measurements of 2 minutes were made.

The electrophysiological data of 7 subjects, 6 women and 1 man, were not recorded properly and are not included in the analyses. The differences between stimuli were tested with an ANOVA for repeated measures; when significant, contrasts with the first baseline were specified.

\section{Results}

In the recordings of the activity of the parotid gland, a peak in activity was expected in response to the saliwa-provoking stimuli. However, the signal oscillated around zero and did not seem to be influenced by the stimuli. Because no peak could be measured, the mean activity in the first 30 seconds (the peak was expected to rise and fall within that period) was calculated. No significant influence of the stimuli was found $(F(5,36)$ $=0.6$, ns.). 
According to the dental roll method the salivation response of the subjects was significantly infuenced by the different stimuli $(F(5,36)=5.9, p<0.001)$, see Figure 1. Subjects salivated more during exposure to lemon $(F(1,40)=13.3, p<0.001)$ and marginally less during wood, compared to the first baseline $(F(1,40)=3.8, p=0.057)$. The swallow method showed significant different salivation responses to the slimuli $(F(5,36)=7.0, p<0.001)$, see Figure 2. Subjects salivated more during exposure to lemon $(F(1,40)=16.1, p<0.001)$ and lasagne $(F(1,40)=4.8, p<0.05)$ and marginally less during wood $(F(1,40)=4.0, p=0.051)$, all compared to the first baseline. Weight gain of cotton rolls and number of swallows were inter-correlated. First, the difference scores compared to the first baseline were calculated. The correlation was not significant during exposure to wood $(r=.1$, ns.), marginally sigmificant during the second baseline and exposure to lemon $(r=.30, p=.067 ; r=.30, p=.062)$ and significant during exposure to chocolate and lasagne $(r=.33, p<.05 ; r=.39, p<.05)$.

\section{1. dental rolls}

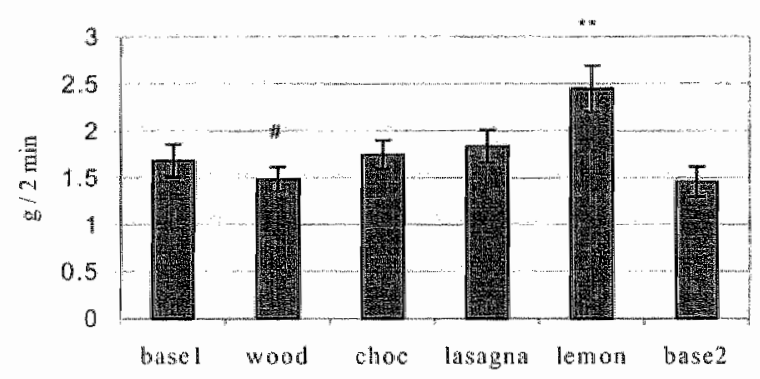

Figure 1. Mean increase in weight of cotron rolls during the first baseline, foum exposure periods and the second baseline. \# $p<0.07, * p<.05, * * p<.001$.

2. swallows

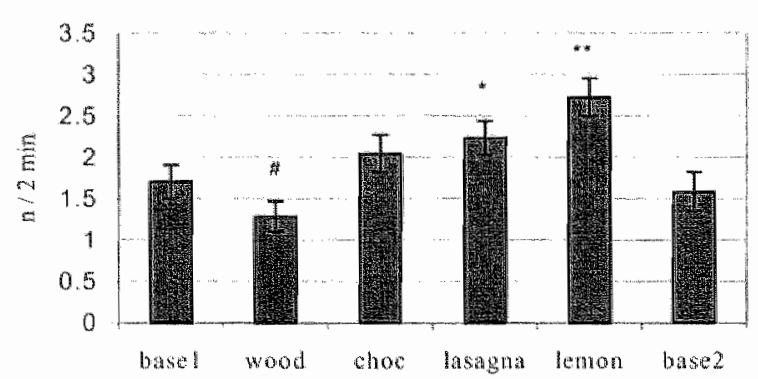

Figure 2. Mean nwmber of swallows dwing the first baseline, four exposure periods and he second baseline. $* 0<07, * p<05, * * 0<001$. 


\section{Discussion}

Three methods for measuring salivary flow were tested. The signal obtained by electrophysiological measurement of the parotid gland did not match the descriptions of Davis et al., $(1990,1996)$ and was not influenced by the saliva-provoking stimuli, although the other two methods indicated that saliva was produced. We know our apparatus were able to measure the low frequent signal we expected from the description of Davis et al. (1990) (the peak has a duration between 10 and 22.5 seconds, which has a frequency between 0.022 and $0.05 \mathrm{~Hz}$ ), because tests with the same filter settings showed we are able to measure an electrogastrogram (EGG), which has a frequency about $0.05 \mathrm{~Hz}$. We also checked the possibility that Davis et at. (1990) described a peak in a rectified and integrated signal, instead of raw signal. In this case the source of the response could be of a higher frequency. However, we made recordings with band pass filters between 10 and $500 \mathrm{~Hz}$ and rectified and integrated the signal. Again, no parotid activity could be recorded. We therefore conclude that electrophysiological measurement of activity of the parotid is not a reliable or valid method.

Both the dental roll method and the swallow method did differentiate between the different stimuli. The correlation between the two methods was not as high as in earlier research $(r=0.57$; Nederkoorn et al., 1999), but again significant or marginally significant during four out of five periods. The absence of a significant correlation during exposure to wood could be caused by an absence of a salivary response and thereby a small distribution between subjects. This experiment therefore reconfirms the validity of the swallow method.

The choice between the methods will depend on the experimental needs. When a laboratory with electrophysiological apparatus is available and for the purpose of the experiment it is important not to influence appetite, counting swallows is recommended. When the measurements are made outside a laboratory setting or the subjects cannot sit quietly and relaxed, the dental roll method is recommended. 
Conditioning model of binge eating 


\title{
4. Cephalic phase responses, craving and food intake in normal subjects ${ }^{1}$
}

\begin{abstract}
Cephalic phase responses (CPRs) are elicited during exposure to food cues. They gear up the body to optimise digestion or they compensate for unwanted changes during a meal. The cue reactivity model of binge eating predicts that CPRs are experienced as craving for food, thereby increasing food intake and playing a role in abnormal eating behaviour.

The present experiment was designed to measure CPRs in normal women and to examine its relationship with craving, food intake and restraint. Results show that normal subjects do react to food exposure with changes in heart rate, heart rate variability (HRV), salivation, blood pressure, skin conductance and gastric activity. These CPRs presumably gear up the body and presumably do not reflect compensatory responses. Significant correlations between restraint and blood pressure, between blood pressure and craving, and between craving and food intake were also found. These results are in line with the cue reactivity model and suggest that research into physiological CPRs and craving in the field of eating disorders is valuable.
\end{abstract}

\footnotetext{
'Nederkoorn, C., Smulders, F.T.Y., Jansen, A. (2000). Cephalic phase responses, craving and food intake in normal subjects. Appetire, $35,45-55$.
} 


\section{Introduction}

Cephalic phase responses (CPRs) of the body are elicited by exposure to the sensory properties of food (e.g. sight, smell and taste) as well as by simply the thought of eating. They can be the direct result of sensory stimulation, but conditioned processes also play a role (Mattes, 1997). When a subject has learned that a cue predicts food intake, cephalic phase responses are elicited by exposure to that cue. CPRs are believed to optimise the digestion, absorption and use of ingested nutrients (Mattes, 1997; Rodin, 1985). Anticipation of the ingestion of food lessens the interruption of the homeostatic balance of physiological prociesses and it increases the amount of food. that the organism is able to eat within one meal. For example, when CPRs are prevented in rats by making the timing of a meal unpredictable, the rats eat smaller meals (Woods, 1991). It seems therefore, that CPRs play an important role in the amount of food someone tolerates. Tolerance is a phenomenon that is usually associated with the intake of drugs, and it refers to the decreasing effects of a drug with repeated administration. When drug administration becomes predictable, organisms learn to anticipate the administration by showing preparatory responses. These preparatory responses at least partly explain drug tolerance (Glautier \& Remington, 1995; Siegel, 1983; Woods, 1991).

CPRs can optimise digestion and lessen the impact of food by gearing up the body and getting it ready to optimise the digestion of food. Indeed it was found that exposure to food increases salivation (Epstein et al., 1997; Franchina \& Slank, 1988; Hodgeson \& Greene, 1980; Nederkoorn, Smulders \& Jansen, 1999; Wooley \& Wooley, 1973, 1981), gastric activity (Stern, Crawford, Stewart, Vasey \& Koch, 1989), and insulin release in humans (Teff \& Engelman, 1996; Teff, Mattes \& Engelman, 1991; Secchi et al., 1995). Nothing is known about the human temperature during exposure, but the body temperature of rats has been found to increase prior to a meal (Woods \& Strubbe, 1994). Preparing the body for the processing of food as well as possible might, however, also mean that anticipatory physiological changes are made which are in the opposite direction. These compensatory responses will counterbalance the disturbing effects of food intake. For example, eating increases the blood glucose and in rats it is found that prior to a spontaneous meal the blood glucose begins to drop (Woods \& Strubbe, 1994). Nicolaidis and Even (in Woods \& Strubbe, 1994) found that the metabolic rate decreases in rats prior to a spontaneous meal, whereas it increases after food intake. In humans, cardiac output, which partly reflects metabolic rate, also decreases after exposure to the sight and smell of food (Andersen ef al., 1992). These opposite reactions prevent blood glucose and metabolic rate from increasing too much above the desirable state. Woods and Strubbe (1994) suggest that more parameters might change preprandially in reverse direction. Of some parameters, the changes in response to food cues are not clear. For example, in some studies no effect of food exposure on heart rate, blood pressure and electrodemal activity was found (Andersen et al., 1992; Overduin \& Jansen, 1996b; Sjövall, Forssell, Haggendal \& Olbe, 1990), but in another study an increase in these parameters was reported (Vogele \& Florin, 1997). And although effects of eating have been found on heart rate 
variability (Lipsitz et al, 1993; Kaneko, Sakakibara, Mitsuma \& Morise, 1995), there is no empirical data on the effects of food exposure.

In sum, CPRs are adjustments of the body to a coming meal, elicited by exposure to food or food cues, either by direct sensory stimulation or by conditioned processes. The body gears up to facilitate the digestion of the food, or its anticipatory responses are compensatory to diminish the negative consequences of food intake. The latter (anticipatory compensatory responses) presumably increase the amount of food one can eat. Of some parameters, the preprandial changes have been thoroughly investigated; yet in the case of others there are still gaps in our knowledge.

Knowing that CPRs play a role in the digestion of food and the tolerance for large meals, it might be hypothesised that they also play a role in eating disorders in which large food intake is a key factor. Subjects with the eating disorders bulimia nervosa and binge-eating disorder are characterised (among other things) by recurrent episodes of uncontrollable eating binges during which a large amount of food is eaten (APA, 1994). CPRs are expected to occur when the eating binges can be reliably predicted. Moreover, because of the frequent extremely large food intake of binge eaters, which perturbs the internal state more than a normal meal does, larger CPRs can be expected in binge eaters than in normal subjects. The cue reactivity model states that these CPRs subjectively are experienced as craving (Jansen, 1994, 1998b; Wardle, 1990). The CPRs to the cues that predict food intake thus increase the craving for the food and thereby make it more difficult for the subject to abstain from eating. From this model, it follows that CPRs add to the continuation of eating binges.

Indeed, when subjects with and without eating disorders are exposed to food cues, more craving (Bulik, Lawson \& Carter, 1996; Fedoroff, Polivy \& Herman, 1997 ; Karhunen, Lappalainen, Tammela, Turpeinen \& Uusitupa, 1997) and physiological reactivity is found in the subjects with abnormal eating patterns. For example, increases in blood pressure and electrodermal activity in binge-eating subjects (Vögele \& Florin, 1997) and increased activity in the frown muscle (the corngator) in restrained eaters (Overduin \& Jansen, 1996b) were found during food exposure. Some studies found a larger increase in salivation after food exposure in subjects with abnormal eating behaviour as compared to normal subjects (Klajner, Herman, Polivy \& Chabra, 1981; LeGoff, Leichner \& Spigelman, 1988; Tepper, 1992; Tuomisto et al., 1999). Others found no effects or even a decrease in saliwation (Bulik of al, 1996; Karhunen et al., 1997). Teff and Engeman (1996) report a correlation between dietary restraint and cephalic phase insulin release, whereas other studies report no effects of food exposure on insulin release in subjects with eating binges (Karhunen el al., 1997), bulimic women and chronic dieters (Broberg \& Bemstein, 1989). No differences were found between nomal women and female binge eaters in free fatty acids and plasma glucose as response to food exposure (Karhunen ef al., 1997).

However, drawing a general conclusion from these findings is problematic. In the studies reported, all kinds of subjects (bulimic patients, obese binge eaters, restrained eaters), diverse cues (standardised food, favourite palatable food items, slides of food) and a variety of physiological parameters were used. In addition, although cue reactivity was repeatedly found, it is not always clear whether the reactivity reflects cephalic phase responses. In most cases, altemative explanations can even not be ruled out. It is possible that in subjects with an eating disonder, exposure to 
"forbidden" food elicits arousal and emotions, which can add to the CPRs or even overrule those responses (Vögele \& Florin, 1997). Moreover, the data reviewed above do not make clear whether an increase in craving for food is related to CPRs, which is postulated by the current cue reactivity model (Jansen, 1998b).

Although research into the role of craving and CPRs in eating disorders is interesting and promising, the premises upon which the research is based are still hypothetical. Before further research with patients is undertaken, the fundamentals ought to be examined. First, the appropriateness of some parameters for measuring CPRS is still not clear (i.e., heart rate, blood pressure and heart rate variability), although these parameters are used in cue exposure experiments (e.g., Vögele \& Florin, 1997). In case of cue reactivity, we do not yet know what reactivity in these parameters exactly means. Does it reflect a gearing up of the body or is it a compensation for the food-induced changes? A second point concerns the prediction of the cue reactivity model; are CPRs indeed experienced as craving? Third, the relationship between CPRs and meal sizes is still unclear. Is the magnitude of CPRs indeed related to the amount of food someone can eat? And a final question of importance is whether subjects who sometines overeat show larger CPRs than nomal subjects.

In the present study, normal subjects were exposed to palatable food and after the exposure they were instructed to eat a large amount. During the intense exposure as well as during and after the meal, physiological and subjective reactivity was measured. Relationships between the physiological measurements, subjective states, caloric intake and overeating tendency were examined.

\section{Methods}

\section{Subjects}

Posters in the university building invited healthy female students to participate in a study on the physiological effects of smelling and eating food. The subjects who volunteered were told that eating a lot of food was part of the experiment. Twenty-four normal weight and non-dieting women were willing to participate. They were instructed not to eat for 5 hours before the experiment. According to the paper and pencil compliance check, all subjects complied with the instructions and were included in the data-analysis. The women had a mean body mass index (BMI, weight $(\mathrm{kg}) /$ height $\left.t^{2}(\mathrm{~m})\right)$ of $21.5(\mathrm{~s} . \mathrm{d} .2 .0)$, their mean age was 20.1 year (s.d. 1.9) and their mean score on the Restraint Scale was 9.4 (s.d. 4.1). 
Measurement

\section{Subjective states}

During the experiment 7 subjective states (hunger, anger, relaxation, fear, sadness, craving for food and nausea) were repeatedly rated by the subject on visual analogue scales ranging from 0 (i.e. not feeling hungry at all) to 100 (feeling very hungry).

\section{Restraint Scale}

A Dutch translation of the Restraint Scale (RS; Herman \& Polivy, 1980) was used. The RS is a self-report questionnaire consisting of 10 items assessing attitudes towards weight and eating as well as the frequency of dieting and weight fluctuations. Scores range from 0 (no restraint) to 35 (high restraint). Subjects scoring high on the RS are characterised by an eating pattern alternating between dieting episodes and periodic overeating (Herman \& Polivy, 1980).

\section{Physiological measurements}

Electrophysiological recordings were all sampled at $250 \mathrm{~Hz}$ and in total 24 recordings of 4 minute-episodes were made.

Heart rate was measured using two $\mathrm{Ag}-\mathrm{AgCl}$ electrodes, one attached on the left side of the subject, the other attached under the right collarbone. R-waves were detected off-line with a template matching procedure, and inter-beat intervals were calculated.

For heart rate variability the power was calculated in three frequency bands: respiratory frequency $(\mathrm{RSA}, 0.15-0.4 \mathrm{~Hz})$, low frequency $(\mathrm{LF}, 0.05-0.15 \mathrm{~Hz})$ and very low frequency (VLF, 0.003-0.05 Hz) (Berntson et al., 1997).

Blood pressure was transduced using a Finapress Monitor (Ohmeda); the Finapress cuff was attached around the middle phalanx of the middle finger of the nondominant hand. The hand was placed on the table, at a height just below the heart region.

Peripheral pulse amplitude was measured by finger pulse photoplethysmography, placing the sensor on the index finger of the non-dominant hand.

Electrogastrography was measured using three $\mathrm{Ag}-\mathrm{AgCl}$ electrodes, one placed on the subject's left side approximately $6 \mathrm{~cm}$ from the midline and just below the lowest rib, another just above the umbilicus and a reference electrode placed on the subjects left ankle. Periods with artefacts were not analysed. The data were resampled at $25 \mathrm{~Hz}$, mean and linear trends were removed, and were filtered with a high pass filter (at $0.0184 \mathrm{~Hz},-3 \mathrm{~dB}, 21)$ and windowed with a cosine bell window $(10 \%)$. After this pre-processing, the data segment was Fourier transformed and the power in the frequency band $2.5-3.5 \mathrm{cpm}$ was computed. Because of large differences betwcen subjects, ratio scores with the baselines were calculated.

As a measure of salivation, swallows were recorded with electromyography and the number of swallows was counted. This proved to be a valid and non-invasive 
method (Nederkoorn, Smulders \& Jansen, 1999; Pomerleau, Fertig, Baker \& Cooney, 1983). The accompanying EMG signal was recorded with $3 \mathrm{Ag}-\mathrm{AgCl}$ electrodes, two electrodes were attached under the left jaw, in the length of the anterior part of the musculus digastricus and a reference electrode was placed on the left mastoid process. Before digitisation, a bandpass filter was set between 10 and $300 \mathrm{~Hz}$, and the signal was rectified and integrated. The digitised epochs were lowpass filtered at $0.4 \mathrm{~Hz}$ ($3 \mathrm{~dB}$, lowpass, Ruchkin \& Glaser, 1978) to smooth the signal. Artefacts like coughing or talking were removed, and by visual inspection of the data, the definition of a swallowing response was determined as a response of the integrated signal above a 5 $\mu V$ threshold, with a minimum of 1.5 seconds between responses.

Skin conductance level was measured with two $\mathrm{Ag}-\mathrm{AgCl}$ electrodes, placed on the thenar and hypothenar eminences of the palm of the non-dominant hand; respiration rate $(\mathrm{cpm})$ was measured with a strain gauge around the subject's middle.

Temperature was measured by a thermistor, placed on the skin in the proximity of the liver. This is thought to be the most sensitive place for measuring changes in surface temperature caused by metabolic process (Westerterp Plantega, Wouters \& ten Hoor, 1990).

Because of artefacts during movements, swallows were not measured during the second exposure period and both swallows and respiration rate were not measured during the eating period.

\section{Procedure}

At the moment a subject registered for participation, she rated diverse kinds of candy and meals, ranging from 0 (do not like it at all) to 10 (like it very much). The ratings were used to select the favourite kinds of food of the subject. For each indiviclual, the experiment started at 1 p.m. or 5 p.m. When the subject came in the laboratory, the electrodes were attached and the subject was instructed to complete the subjective ralings. The subjective ratings were repeated 24 times during the experiment (see the arrows in Figure 1). There were six measurement periods (see Figure 1): baseline (8 min.), exposure ( 8 min.), intensified exposure ( 8 min.), second baseline ( 8 min), eating period ( $32 \mathrm{~min}$.) and a third baseline or rest period after eating ( $32 \mathrm{~min})$. During the baseline measurements the subject was instructed to sit motionless and to relax. During the food exposure, three plates with diverse kinds of preferred food were placed on a table in front of the subject. She was instructed to bend over the food, to look at it and to smell it, and to imagine how it would taste. After 8 minutes, the intensified exposure started; the subject was instructed to taste the food by licking it and to expectorate, in order to prevent consumption. After the intensified exposure, the plates were removed and a second baseline recording was made to allow physiological responses come to rest. Then the eating period started; the subject received her favourite meal (heated in the microwave), a dessert and various kinds of candy. She was instructed to eat as much as she could without becoming uncomfortable or sick. She also received a drink of her choice (without alcohol or caffeine). The eating period lasted 32 minutes. Thereafter, the food was removed and the subject sat quietly for another 32 minutes. Finally, the subject filled in the Restraint Scale and a 
questionnaire about compliance with the instructions and use of medications. Her height and weight were measured and she received a financial reward.

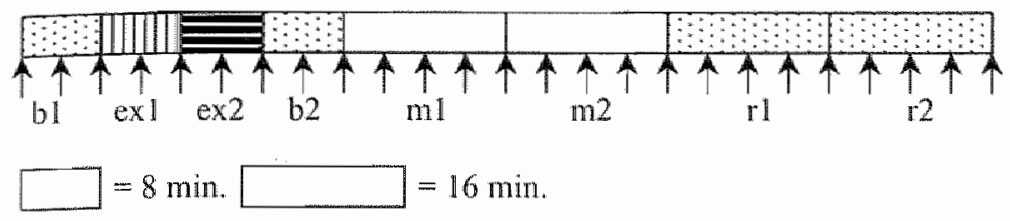

Figure 1. Time scheme of the experiment $\uparrow=V A S ; b l=f$ wst baseline; $x l=$ expostare: $e x 2=$ intensified exposure; $b 2=$ second baseline; $m l=$ first meal period; $m 2=$ second meal period: $r l=$ first rest period after the meal; $r 2=$ second rest period after the meal.

Data reduction and analysis

The effects of food exposure and eating were analysed in separate ANOVAs for repeated measures. Greenhouse-Geisser correction was applied when Mauchly's test of sphericity was significant. For the effects of food exposure the average over eight minutes was calculated; for the effects of eating an average over 16 minutes was calculated. If the ANOVA was significant, simple contrasts were specified with the baseline as reference (the first baseline in the exposure analyses, the second baseline in the eating analyses) in post hoc analyses. Because of technical failure, blood pressure of 5 subjects was not measured and because of too many artefacts in the recorded signals, four subjects were removed from the EGG-data analyses and two subjects of the swallow analyses.

\section{Results}

\section{Food exposure}

The subjective ratings indicated effects of food exposure on craving for food $(F(3,69)$ $=16.6, p<0.001)$ and hunger $(F(3,69)=10.1, p<0.001)$, but not on anxiety, anger, satiety, sadness, nausea and relaxation. The post hoc contrasts showed that craving and hunger increased during the exposure and decreased a little during the second baseline, though were still elevated compared to the first baseline (see Figure 2).

The overall ANOVAs revealed significant increases of heart rate $(F(3,69)=$ $14.8, p<0.001)$, the low frequency component of heart rate variability $(\mathrm{LF}, F(3,69)=$ $8.6, p<0.001)$, diastolic $(F(3,54)=23.2, p<0.001)$ and systolic blood pressure $(F(3,54)=15.8, p<0.001)$, temperature $(F(3,69)=4, p<0.05)$, skin conductance 
level $(F(3,69)=19.5, p<0.001)$, and number of swallows $(F(2,42)=12.2, p<0.001)$ during food exposure. The RSA component of heart rate variability decreased significantly $(F(3,69)=3.9, p<0.05)$. A marginally significant effect was found on gastric activity, which increased during the exposure $(F(3,57)=3.7, p=0.065)$. No effects were found on the very low component of heart rate variability (VLF), finger pulse amplitude and respiration rate. Contrasts showed that heart rate, HRV-LF, skin conductance and number of swallows all significantly increased during food exposure and decreased again to a non-significant level during the second baseline, compared to the first baseline. Diastolic and systolic blood pressure increased during food exposure and remained elevated during the second baseline; temperature remained marginally significantly elevated. A third pattern can be seen in the respiratory sinus arrhythmia of heart rate variability (HRV-RSA); food exposure had no significant influence on this component, but during the second baseline the power in this frequency decreased significantly. All changes are shown in figure 3.

\section{Effects of a large meal}

The mean caloric value of food eaten by the subjects was $1277 \mathrm{kcal}$. (SD 271). There was no significant difference in the amount eaten between subjects who started the experiment at 1 p.m. and subjects who started at 5 p.m. $(F(1,23)=0.94)$. The large meal had a signifficant influence on hunger $(F(4,92)=190.9, p<0.001)$, craving $(F(4,92)=218.6, p<0.001)$, satiety $(F(4,92)=1.54, p<0.001)$, nausea $(F(4,92)=8.8$, $p<0.005$ ) and relaxation $(F(4,92)=11.2, p<0.005$ ) (see figure 2). Contrasts reveal that hunger and craving for foodl were high during the baseline, decreased during the meal, and stayed low during the resting period. Ratings of satiety showed the reverse pattern: satiety was low during baseline, increased during the meal, and stayed high during the resting period. Nausea significantly increased during the final eating period, and decreased to a non-significant level during the resting period. During the resting period after the meal, subjects were more relaxed than during the baseline or during the meal. No effects were found on anxiety, anger and sadness.

There were significant influences of the meal on heart rate $(F(4,92)=64, p<$ $0.001)$, heart rate variability $(\operatorname{LF}(F(4,92)=7.8, p<0.005)$ and $\operatorname{VLF}(F(4,92)=6.6, p$ $<0.005)$ ), diastolic $(F(4,72)=7.1, p<0.005)$ and systolic blood pressure $(F(4,72)=$ $15.3, p<0.001)$, finger pulse amplitude $(F(4,92)=4.9, p<0.01)$, skin temperature $(F(4,92)=6.0, p<0.005)$ and skin conductance $(F(4,92)=15.6, p<0.001)$. A marginally significant increase in gastric activity was found $(F(4,76)=3.0, p=0.066)$ (see Figure 3 ). Contrasts revealed that during and after the meal heart rate was elevated. The power in the low components of heart rate variability decreased significantly during the second eating period and remained low after the meal. The power in the very low components of heart rate variability declined during both eating periods and the first resting period, during the second rest period after the meal it 

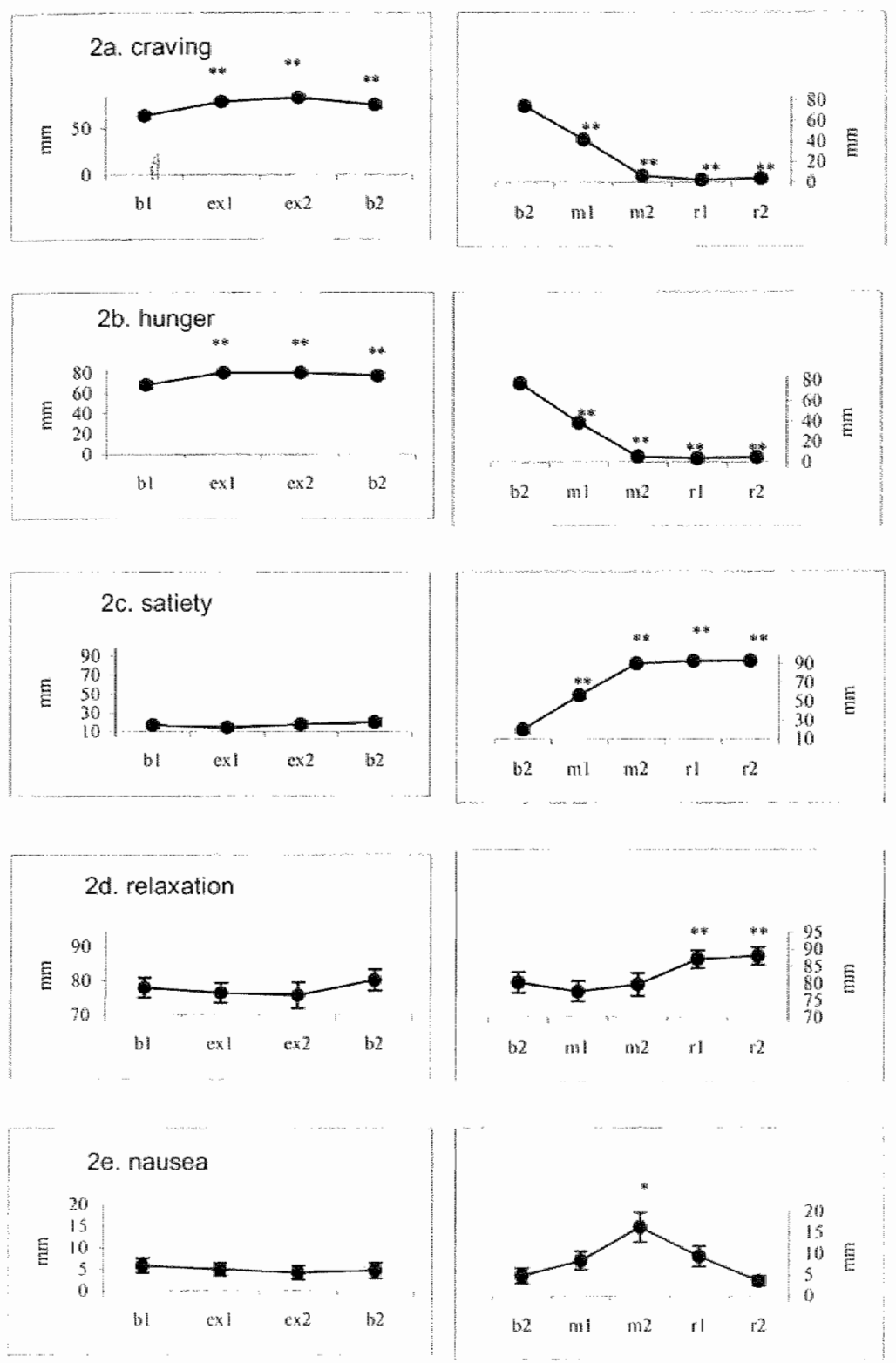

Figure 2. Mean subjective ratings of craving (a), hunger (b), satrety (c), relaxation (d), and nawsea (e) with S.E.M. during food exposure and binge eating (large meal) bI = first baseline, exl $=$ exposine, $x_{2}=$ intensified exposure, $b 2=$ second baseline, $m /=$ frst meal period, $m_{2}=$ second meal period, $r=$ first rest period after the meat, $12=$ second rest period after the meal. * $p<0.05$.** $p<0.01$. 
Chapter 4

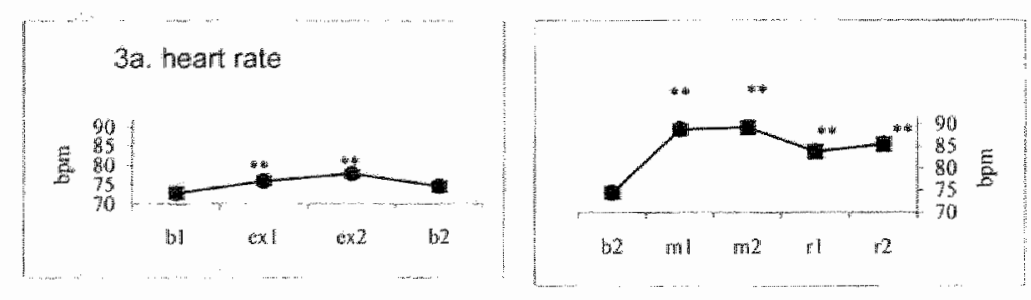

3b. heart rate variability - rsa
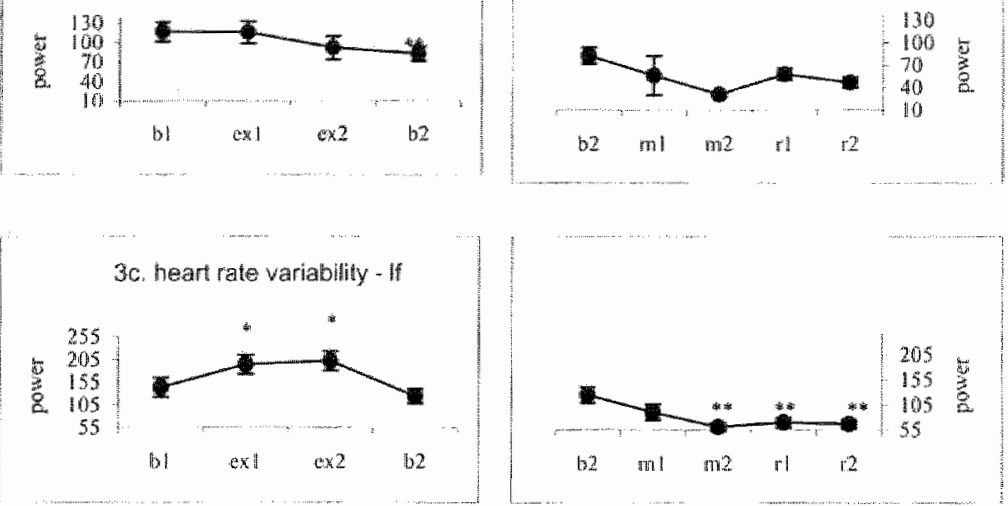

$3 d$. heart rate variability - vif
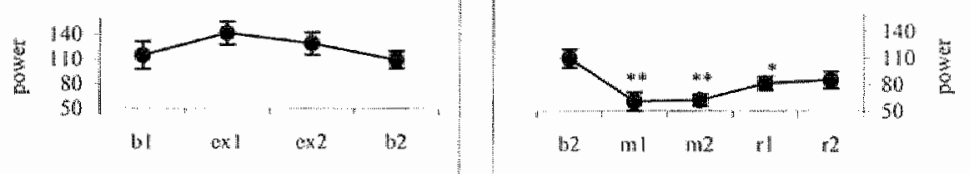

3e. diastolic blood pressure

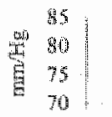
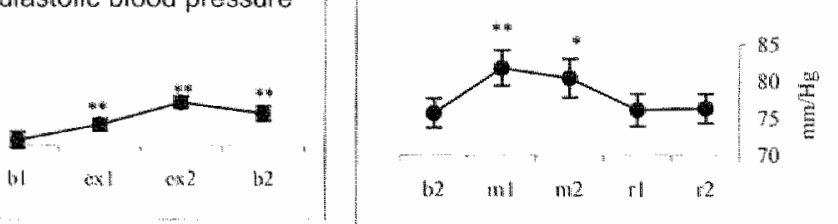

3f. syslolic blood pressure
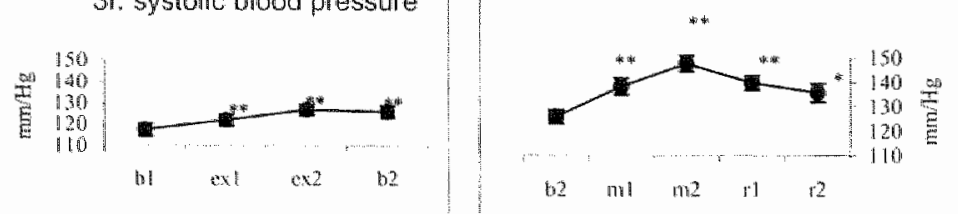

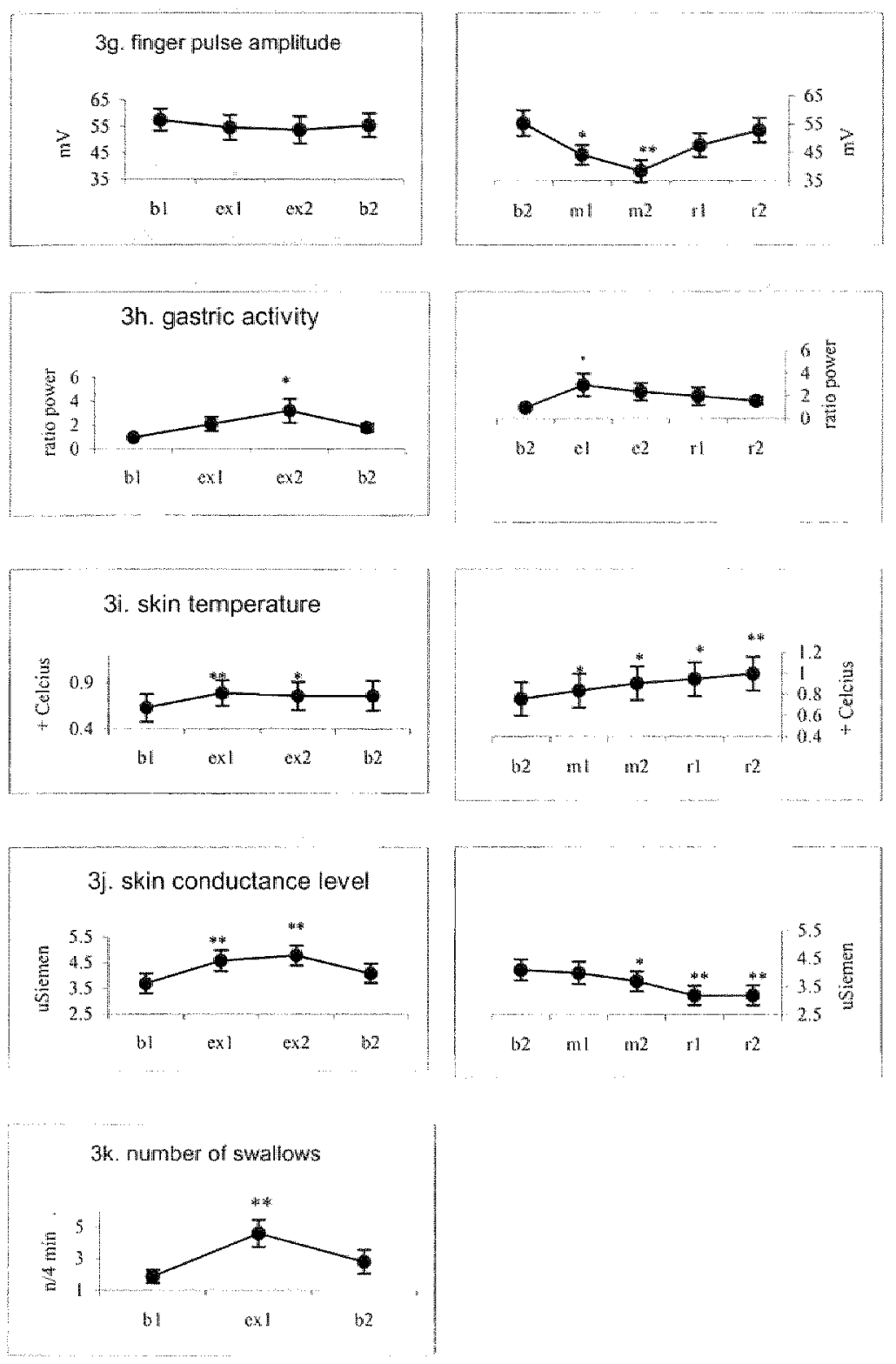

Figure 3. Mear physiological reactions of heart rate (a), HRV-RSA (b), HRV-LF (c), HRVVLF (d). DBLP (e), SBLP (f), finger pulse amplitude (g), gastric activity (h) temperature (i), SCL (j). and number of swallows (k) with S.E.M. during food exposure and binge eating $b /=$ first baseline, exl $=$ exposure, exz $=$ intensified exposure, $b 2=$ second baseline, $m 1=$ first meal period, $m 2=$ second meal period, $r 1=$ first rest period after the meal, $r 2=$ second rest period after the meal. $* p<0.05$, ** $p<0.01$. 
increased again to a non-significant level. Diastolic blood pressure increased during the meal and decreased again after the meal; systolic blood pressure increased during the meal and stayed elevated after the meal. Finger-pulse amplitude decreased during the meal and increased again to a non-significant level after the meal. This indicates that during the meal there is peripheral vasoconstriction. The skin temperature increased during and after the meal. Skin conductance level decreased during the second meal period and after the meal. Power in the main frequency of gastric activity showed a marginally significant increase during the meal and decreased after the meal. There was no significant effect of the meal on the RSA component of heart rate variability.

Relationship between CPRs, subjective craving and hunger and the intake of food

Partial correlations between CPRs, craving, hunger and food intake were calculated, thereby controlling for the subjective ratings of anger, relaxation, fear, sadness and BMI. First, the relation between cue reactivity on the one hand and craving and hunger on the other was tested. Ratings of craving during the first exposure period correlated significantly with diastolic blood pressure $(r=0.62, p<0.05)$ and systolic blood pressure $(r=0.64, p<0.05)$. Hunger did not correlate significantly with CPRs.

To test the hypothesis that subjects with increased reactivity are able to eat more, the amount of calories ingested during the meal. was correlated with CPRs. No significant correlation between physiological reactivity and food intake was found. There was, however, a positive correlation between the increase in subjective craving during the first baseline period and the amount of ingested calories $(r=0.58, p<$ $0.05)$.

Partial correlations between restraint scores, CPRs, craving and meal size were also calculated, thereby controlling for emotions and BMI. Restraint correlated with dinstolic blood pressure $(r=0.66, p<0.05)$ and systolic blood pressure $(r=0.64, p<$ $0.05)$ during food exposure.

\section{Discussion}

The present experiment was designed to study the relationships between (a) physiological reactivity first during food exposure and then during food intake, (b) craving and CPRs, (c) CPRs and food intake, and (d) restrained eating behaviour and CPRs.

Conceming (a) the physiological reactivity during food exposure and food intake, it can be concluded that food exposure caused a strong increase in hunger and craving. Exposure also had a pronounced effect on physiology: salivation, temperature, heart rate, HRV.LF, HRV-RSA, skin conductance, diastolic and systolic 
blood pressure all changed significantly during the exposure. The changes in physiological reactivity during food exposure and food intake were in the same direction for saliva, temperature, blood pressure, heart rate and gastric activity. The present findings on saliva and gastric activity are consistent with earlier findings (Epstein et al., 1997; Franchina \& Slank, 1988; Hodgeson \& Greene, 1980; Nederkoorn et al., 1999; Stern et al., 1989; Wooley \& Wooley, 1973, 1981), and the increase in temperature during food exposure is in line with the preprandiall rise in temperature found in rats (Woods \& Strubbe, 1994). Also an inctease in heart rate during the meal has been found earlier (Vaz et al., 1995). A heart rate increase during exposure was found once (Vögele \& Florin, 1997), but not always (Andersen et al., 1992; Overduin \& Jansen, 1996; Sjövall et al, 1990). Andersen ed al. (1992) found a decrease in cardiac output during food exposure, whereas we found a heart rate increase. Note, however, that cardiac output is not the same as heart rate. Cardiac output is determined by the strength and frequency of heart contractions as well as the resistance against which the heat is pumping. Unfortunately, we did not measure cardiac output.

Opposite changes during exposure and during the meal were found in the low frequency (LF) of heart rate variability and in the skin conductance. The LF variability of heart rate is a product of both sympathetic and parasympathetic influences and is often thought to be an index for mental effort or cognitive processes (Berntson et al., 1997). The increase found during the exposure might veflect the mental effort that is required when concentrating on the smell, sight and taste of the food. Skin conductance, which is an index of activity of sweat glands, increased during food exposure and decreased during and after the meal. Skin conductance can be interpreted as a measure of arousal. The increase during food exposure and the decrease during and after the meal is in accordance with the changes in the LF of heart rate variability. The decrease of the LF of HRV and of skin conductance during and after the meal might be the result of increased familiarity or boredom of the situation, which perhaps decreased arousal and attention. The subjects allso reported a significant increase in relaxation after the meal. It does not therefore seem feasible that the changes serve a compensatory role.

The RSA variability of heart rate (HRV) decreased during the second baseline. HRV-RSA is generally believed to provide an index of vagal activity, and is found to be influenced by respiratory rate and depth (Berntson et al., 1997). Why the subjects showed less vagal activity during the second baseline is not clear. During the meal, no significant changes were found. The very low frequency of heart rate only changed during the meal, as did finger pulse amplitude.

Our findings of an increase in diastolic and systolic blood pressure during food exposure were reported before (Vögele \& Florin, 1997), although the documented effects of eating on blood pressure are inconsistent. Both increases in systolic blood pressure (De Mey et al., 1989; Vaz et al., 1995) and a lack of changes (Lipsitz et al., 1993; Kaneko ef al., 1995) are reported. Probably the large size of the food intake contributed to the increase found during and after the meal in this study.

All in all, the CPRs found in this study can mostly be interpreted as gearing up the body to prepare for food intake. The low frequency of HRV and clectrodermal 
activity changed in opposite directions, but an interpretation in terms of compensatory responses is questionable.

Secondly, the prediction of the cue reactivity model that CPRs are subjectively experienced as craving was tested. Significant correlations were found between craving and systolic and diastolic blood pressure. Although correlations do not indicate a causal relationship and not all CPRs significantly correlated with craving, this finding does support the hypothesis that at least some CPRs are experienced as craving.

The third point under study was the question whether CPRs were related to the amount of food a subject eats. They were not: we did not find a significant correlation between CPRs and food intake. The subjects were pressed to eat as much as possible and it cannot be ruled out that, if the subjects were given the opportunity to eat as much as they liked without pressure, a relationship would be found between CPRs and food intake. The increase in subjective reactivity (craving) during food exposure, however, was significantly correlated to food intake. This finding supports the role of craving in the regulation of food intake.

Finally, with respect to the fourth point whether subjects" restraint is related to the amount of CPRs, it was found that systolic and diastolic blood pressure correlated significantly with restraint scores. Thus, subjects who are inclined to alternate between dieting episodes and periodic overeating showed more physiological reactivity during food exposure. This effect is robust, the more because the absolute restraint scores were quite low and there was not much variability between subjects. Nevertheless, a strong relation between restraint and CPRs was found, suggesting that exposure to food in particular elicits CPRs in restrained eaters. This finding is in line with the cue reactivity model, which holds that a more chaotic eating pattern (alternating between restricted eating and overeating) will induce larger CPRs during food exposure (see Jansen, 1998). Research into CPRs thus might benefit from using highly restrained. eaters.

In the present study we found several interesting coninections. A restrained eating style was significantly related to blood pressure, blood pressure was significantly related to craving, and craving was significantly related to food intake. There was, however, neither a direet rellationship between restraint on the one hand and craving or food intake on the other, nor a direct relationship between blood pressure and food intake. A common underlying factor might explain the diverse relationships. This factor is not $\mathrm{BMI}$, nor emotionality, because by using partial correlations we controlled for the influences of weight and emotions. What other factor(s) might have influenced blood pressure, craving and food intake? The predictability of cating high calorie food and the quantity eaten will determine the strength or intensity of a learned association between cues and high calorie food. In its turn, the strength of conditioning will influence the size of CPRs, craving and food intake. Then, subjects eating large amounts of high calorie food in a predictable way will show larger CPRs, craving and food intake.

Although the subjects were not explicitly observed in the present experiment, they might have felt observed. Apart from the electrodes on their body, the experimenter entered the lab every four minutes to present a questionnaire. This might have inhibited food intake of, in particular, the more restrained subjects ("eating less in 
the presence of others and eating more when alone" is one of the items in the Restraint Scale). Although highly restrained subjects ate as much as unrestrained subjects, their physiological reactivity to food cues was stronger. Following this line of reasoning, one would expect that when restrained eaters are alone at home, their stronger physiological reactivity in the presence of food cues would disinhibit them, ending up in increased food intake. In social and laboratory situations, inhibition because of being observed could counteract this effect. Further research is needed to sort out the factors that influence CPRs, craving for food and caloric food intake.

In sum, food exposure leads to physiological reactivity in normal subjects and this reactivity can be measured by non-invasive techniques. The responses found in the present study might be interpreted as gearing up the body to digest the coming food as well as possible. Individual differences in restrained eating correlated to the size of the cephalic phase responses, namely systolic and diastolic blood pressure. Blood pressure also correlated with subjective ratings of craving. Craving for food, in turn, was significantly correlated to food intake. These results thereby support the cue reactivity theory and confirm that research into CPRs and craving in the field of eating disorders is valuable. 


\section{Cue reactivity and regulation of food intake $\mathrm{e}^{1,2}$}

\section{Abstract}

A robust finding in eating research is the so-called counterregulation in restrained eaters. This means that while normal subjects eat less during a taste test, after they consumed a preload, restrained eaters consume more. An explanation is that food exposure causes stronger physiological preparatory reactivity in the restrained eaters. This reactivity is experienced as craving, and leads to an increased food intake.

To test this theory 46 high and low restrained eaters were exposed to food or soap, while physiological measurements were made. Afterwards the subjects performed a taste test, during which food intake was secretly measured.

Unrestrained eaters showed an increase in heart rate, gastric activity and saliva during food exposure, however restrained eaters did not. Gastric activity significantly correlated with food intake. Group or exposure type did not influence food intake. It can be concluded that unrestrained eaters prepared for food intake, whereas the restrained eaters did not. A possible explanation is that restrained eaters used cognitive suppression to block physiological responding, thereby controlling their food intake.

\footnotetext{
'Nederkoom, C. \& Jansen, A. (2002). Cue reactivity and regulation of food intake. Earing Behawors, 3, 61-72.

${ }^{2}$ The authors acknowledge with gratitude the support of Eric Rassin with the WBSI data
} 


\section{Introduction}

A large group of people is struggling with their food. intake, trying to restrict it, but often fail to do so. Herman and Mack (1975) performed an elegant experiment, using the so-called preload paradigm, in which this phenomenon is shown. In that experiment, unrestrained eaters showed normal regulation of their eating behaviour; after they ate a preload (milkshake), they ate less ice cream during a subsequent taste test than when they ate no preload. Restrained eaters, however, defined as subjects who want to restrict their food intake, consumed less during a taste test when they did not eat a preload, but they consumed more during the taste test when they did eat a preload. This illogical behaviour is called counterregulation and Herman and Mack's experiment intiated a large body of research. Restrained eaters repeatedly showed abnormal regulation of food intake (for an overview, see Boon, 1998). How can this eating pattern of restrained eaters be explained? A widespread cognitive explanation stems from the boundary model (Herman \& Polivy, 1984). In this model, biological boundaries determine when a person feels hungry or satiated and thereby when a person starts and stops eating. Restrained eaters have another self-imposed boundary, marking their maximum desired consumption, the so-called diet boundary. As long as this boundary is not broken, the restrained eater succeeds in restricting food intake. When this diet boundary is broken, for example after eating the preload, restrained eaters have disinhibitive thoughts, like "I've already blown my diet, I might as well continue to eat", and start overeating. However, restrained eaters also showed abnormal regulation after exposure to the sight, smell, or thought of food, without actually eating it (Jansen \& van den Hout, 1991; Federoff, Polivy \& Heman, 1997). These findings cannot be explained with the disinhibitive thoughts of the boundary model; the "preload" was not consumed, and thus no diet rule was broken. Furthermore, no evidence of disinhibitive thoughts was found when restrained eaters were instructed to think aloud during the preload condition (Jansen, Merckelbach, Oosterlaan, Tuiten \& van den Hout, 1988).

An alternative explanation for the counterregulation phenomenon stems from the cue reactivity theory. This theory states that when a person regularly has eating binges, and these binges are reliable preceded by certain cues (e.g., the sight, smell and laste of the food, environment, cognitions and emotions), these cues become predictors of the start of a binge. Exposure to these cues induces conditioned physiological reactivity, which can prepare the person for the intake of food. In normal subjects, physiological responses to food cues are widely documented and called cephalic phase responses (Mattes, 1997; Nederkoorn, Smulders \& Jansen, 2000). Binge eaters are expected to show even larger cephalic phase responses, because the enormous amount of food intake during a binge threatens the homeostatic balances of the body, and anticipation is more important compared to nomal food intake. In addition, more intense unconditioned stimuli, in this case the food intake strengthens the conditioning. The cue reactivity is experienced as craving for the food and triggers an eating binge (Jansen, 1994; 1998; Wardle, 1990). The theory originates in the addiction field, were increased psychophysiological reactivity and craving is found when the addict is exposed to drug/alcohol cues (Glautier \& Remington, 1995; Robbins, Elrman, 
Childress \& O'Brien, 1997) and studies suggest that craving for a substance is a classical conditioned response (Drummond, Tiffany, Glautier \& Remmington, 1995). At least a part of the restrained eaters show an eating-pattern of dieting and overeating, which resembles the eating pattern of subjects with eating binges. Applied to the preload paradigm, the cue reactivity model of binge eating states that exposure to a preload, either by seeing and smelling or actually eating it, will elicit conditioned physiological responses and craving in the restrained eater. This in turn leads to increased food intake and counterregulation. From the model it also follows that, when not exposed to the preload or other binge cues, the restrained eater is able to control food intake and eats less.

In sum, the cue reactivity model predicts that: (1) Restrained eaters show more physiological reactivity when exposed to binge cues than unrestrained eaters. (2) Cue reactivity is experienced as craving and (3) the increased reactivity and craving during the exposure leads to increases in the food intake of the restrained eaters during the taste test afterwards. Furthermore, the cognitive theory on overeating predicts that (4) a preload (or exposure to "forbidden" food) elicits disinhibitive thoughts in restrained eaters, which lead to an increased food intake during the taste test.

The present experiment was designed to test these four hypotheses. Restrained and unrestrained women participated in an adjusted "preload" experiment, in which half of them were exposed to the sight and smell of food, without consuming it, the other half were exposed to control stimuli. During the exposure, physiological reactivity was measured. Before and after the exposure, the subjects rated several subjective states, like craving for food. Afterwards, the participants performed a taste test and food intake was measured. At the end, the subjects rated retrospectively the frequency of disinhibitive thoughts during the exposure period.

\section{Methods}

\section{Participants}

As part of another study, first year students of psychology and health sciences of the University Maastricht were invited to complete a set of questionnaires, anongst which a Dutch translation of the White Bear Suppression Inventory (WBSI, Wegner \& Zanakos, 1994) and the Restraint Scale (RS; Herman \& Polivy, 1980). 173 participants returned the questionnaires. Women with scores higher then 15 and lower then $10(1 / 2$ std. of the mean in earlier studies of the authors) on the RS were invited by telephone to participate in a smell and taste experiment. Forty-six women participated. The data of two participants were excluded from the analyses, one participant because of use of medication (Prozac) and one participant because she saw through the expcrimental manipulations and purpose of the study. All participants filled in the RS again directly after the experiment, to obtain scores directly related to the time of the experiment. On base of the mean RS score during the experiment (11.9), twenty participants with 
higher scores were classified as restrained eaters and twenty-four participants with lower scores were classified as unrestrained eaters (mean scores are revealed in table 1).

\section{Measurements}

Subjective states (relaxation, hunger, anger, craving for food, anxiety and nausea) were scored on visual analogue scales (VAS), twanging from 0 (e.g. not at all angry) to 100 (e.g. very angry).

The subjects rated the frequencies of stereotypical disinhibitive thoughts during the taste test retrospectively, ranging from 0 (not thought this at all) to 100 (thought it all the time). The disinhibitive thoughts were: "My day is ruined now, I might as well continue to eat", "I can not control myself" "Everything must be eaten", "Stay away from the food", "I don't have myself in hand" and "I have already eaten too much now, let's take another bite". The scores were summed up to obtain an overall score.

A Dutch translation of the RS (Herman \& Pollivy, 1980) was used to measure the intention to restrain food intake. Subjects scoring high on the RS are characterised by an eating pattern altemating between dieting episodes and periodic overeating (Herman \& Polivy, 1980). A Dutch translation of the EDE-Q (Fairburn \& Beglin, 1994) was used to measure to existence of specific eating psychopathology. The EDE$Q$ informs about restraintness, as well as eating, weight and shape concern and contains seven items that are not included in the sum score. One of these items asks the number of eating binges during the last 28 days. The WBSI (Wegner \& Zanakos, 1994) exists of 15 items and measures the habitional tendency to suppress unwanted thoughts. The participants also completed a questionnaire that checked compliance with the instructions and use of medication. Furthermore, the women had to describe the aim of the experiment, to check whether they were conscious of the fact that the taste test was a pretext and that actually food intake measured.

Physiological measurements were all sampled with $250 \mathrm{~Hz}$. Heart rate, blood pressure, electrogastrography, salivation, skin conductance and skin temperature were measured. Physiological measurements were made during the baseline ( 4 minutes) and during the exposure period ( 8 minutes).

Heart rate was measured by three Ag-AgCl electrodes; two attached over the heart region and a reterence electrode was placed on the left elbow. R-waves were detected off-line with a template matching procedure, and beats per minute were calculated.

Blood presswre was transduced using a Finapress Monitor (Ohmeda); the Finapress cuff was attached around the middle phatanx of the middle finger of the nondominant hand. The hand was placed on a box on the table, which height was the same as the heart region.

Electrogastrography was measured by three $\mathrm{Ag}-\mathrm{AgCl}$ electrodes, one placed on the participants left side approximately $6 \mathrm{~cm}$ from the midline and just below the lowest rib, another just above the umbilicus and a reference electrode placed on the participants left elbow. The signal was off-line resampled at $25 \mathrm{~Hz}$, mean and linear trends were removed, and the signal was filtered with a high pass filter (at $.0184 \mathrm{~Hz},-3$ 
$\mathrm{dB}$ ) and windowed with a cosine bell window (10\%). After the pre-processing, the epochs of 4 minutes were Fourier transformed and power was calculated in the frequency band between $2.5-3.5 \mathrm{cpm}$. To diminish large individual differences in scores, caused by among others the thickness of the fat layer on the stomach, ratio scores with the baseline (exposure / baseline) were calculated.

As a measure of salivation, swallows were recorded Nederkoorn, Smulders \& Jansen, 1999; 2000; Pomerleau, Fertig, Baker \& Cooney, 1983). The accompanying EMG signal was recorded with $3 \mathrm{Ag}-\mathrm{AgCl}$ electrodes, two electrodes were attached under the left jaw, in the length of the anterior part of the musculus digastricus and a reference electrode was placed on the left mastoid process. Before digitisation, a bandpass filter was set between 10 and $300 \mathrm{~Hz}$, and the signal was rectified and integrated. The digitised epochs were lowpass filtered (at $0.4 \mathrm{~Hz},-3 \mathrm{~dB}$ ) to smooth the signal. Artefacts like coughing or talking were removed, and by visual inspection of the data, the definition of a swallowing response was determined as a response of the integrated signal above a $5 \mu \mathrm{V}$ threshold, with a minimum of 1.5 seconds between responses.

Skin conductance was measured with three $\mathrm{Ag}-\mathrm{AgCl}$ electrodes, placed on the thenar and hypothenar eminences of the palm of the non-dominant hand, the reference electrode was placed on the back of this hand.

Temperature was measured by a thermistor, placed on the skin in the proximity of the liver. "This was thought to be the most sensitive place for measuring changes in surface temperature caused by metabolic processes (Westerterp-Plantega, Wouters \& Ten Hoor, 1990).

\section{Procedure}

The participants were instructed not to eat for three hours before the experiment. After entering the laboratory, electrodes were attached and signals were checked. The subject was told that physiological reactivity to several odours would be measured. In front of the participant a round table was turning, and paused for a few seconds every quarter of the plateau. The participant was instructed to sit quietly and relaxed. First, a baseline measurement of 4 minutes was made. Then the participant rated its subjective states on the VAS scales. Thereafter, four bowls were placed on the turning table, just under the nose of the participant. In the food condition, the bowls contained respectively chocolate raisins, a kind of spice nuts (typical Dutch one-bite cookies, called "pepenoten"), savoury coated peanuts and small pieces of liquorice (called "kokindjes"). In the control condition, the bowls contained four different kinds of small pieces of bath soap. All bowls were filled with large amounts of the stimuli. The participant was instructed to concentrate on the smell of the stimuli and to sit quict and relaxed again. The exposure continued for 8 minutes, during which physiological measurements were made. Then the participant rated its subjective states again on the VAS scales. The turning table was removed and the bowls were placed on the desk, in front of the participant. The participant had to fill in a questionnaire about the smell of the four stimuli. Ones the questionnaire was filled in, the taste test began. The women in both conditions received four bowls with food stimuli and a questionnaire about the 
taste of the food items. Subjects in the experimental group tasted the food they had smelled, subjects in the control group also tasted food, in bowls that were exactly comparable to the bowls of the experimental group. The participant was told that she could eat as much as she wanted or needed to make a proper judgement over the taste. Then the participant was left alone. Fifteen minutes later, the experimenter came back and removed the bowls. The participant filled in the remaining questionnaires (RS, EDE-Q and compliance, in that order), their weight and height was measured and she received a small grant for participation.

\section{Data reduction and analyses.}

Mean physiological responses were calculated. Baseline scores, BMI and time of measurement were included as covariates. All variables were analysed using 2 (restrained/unrestrained) X 2 (food/soap exposure) between-subjects analyses of variance (ANOVA).

\section{Results}

Unrestrained and restrained eaters did not differ in age. Restrained eaters however, had significant higher BMT and scored higher on the RS and the EDE-Q. Mean age, BMI and scores on the $\mathrm{RS}$ and $\mathrm{EDE}, \mathrm{Q}$ are revealed in Table 1.

Table 1. Mean and standard error of age, BMI, RS and EDE-Q for both groups.

\begin{tabular}{llll} 
& $\begin{array}{l}\text { restrained eaters } \\
(\mathrm{n}=20)\end{array}$ & $\begin{array}{l}\text { unrestraned eaters } \\
(\mathrm{n}=24)\end{array}$ & difference \\
\hline age & $19.7(0.6)$ & $19.0(0.2)$ & $F(1,43)=1.5, \mathrm{~ns}$ \\
BMI & $24.1(0.5)$ & $21.3(0.5)$ & $F(1,43)=14.5, p<.001$ \\
RS & $18.2(1.0)$ & $6.8(0.5)$ & $F(1,43)=114, p<.001$ \\
EDE-Q(total) & $2.3(0.3)$ & $0.6(0.1)$ & $F(1.43)=1.7 .8, p<.001$ \\
\hline
\end{tabular}

The first hypothesis of the cue reactivity theory (1) was that restrained eaters show more reactivity to food exposure, compared to control exposure than unrestrained eaters. Several physiological effects were found. A significant main effect of group on heart rate emerged. The unrestrained eaters showed a higher heart rate than restrained eaters did $(F(1,43)=15.9, p<.001)$. A marginal significant effect of condition was found, overall, the subjects showed a higher heart rate during food exposure than during control exposure $(F(1,43)=4.0, p=.052)$. There was also a 
significant interaction effect $(F(1,43)=4.1, p<.05)$; the heart rate of the unrestrained eaters was higher during food exposure, whereas there was no effect on the heart rate of the restrained subjects (see Figure la). Gastric activity also showed a significant interaction $(F(1,43)=8.4, p<.01)$. Restrained eaters had a larger increase in gastric power during control exposure than during food exposure, whereas unrestrained eaters showed the opposite pattern (see Figure 1b).

The same pattern was found for swallowing; restrained eaters swallowed more often during the control exposure than during food exposure, unrestrained eaters swallowed more during food exposure $(F(1,43)=5.0, p<.05)$, see Figure $\mid c$.

Restrained eaters had a higher skin temperature than unrestrained eaters, irrespective of exposure type $(F(1,43)=5.9, p<.05)$. No effects were found on blood pressure (systolic, diastolic or mean blood pressure) and skin conductance level.

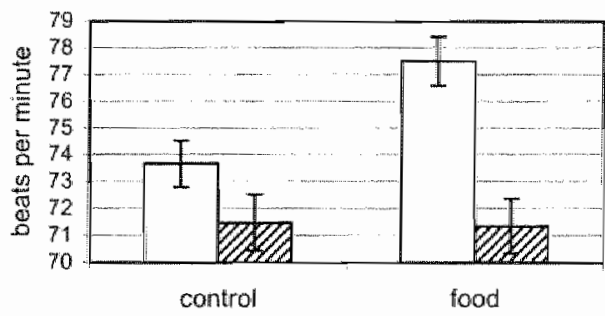

$\square$ unrestrained

Er restrained

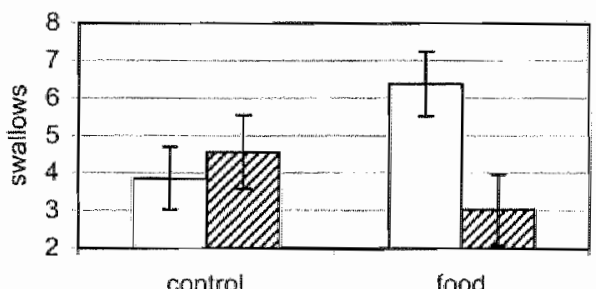

पunrestrained

Drestrained

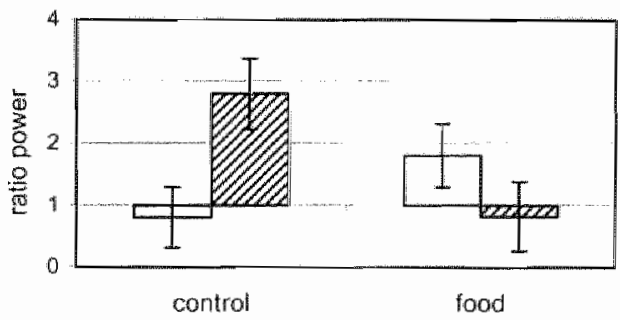

Duntestrained

Qrestrained

Figure 1. Mean and standard error of hear rate (la), salivation (M) and gastric activity (1c) during control and food exposure, compared to the baseline, of restrained and unrestrained eaters. 
The second hypothesis of the cue reactivity theory states that the physiological reactivity was experienced as craving. Both groups reported an increase in craving after food exposure compared to exposure to the control stimuli $(F(1,43)=12.3, p<$ $.001)$. However, there was no significant correlation between any physiological measurement and craving.

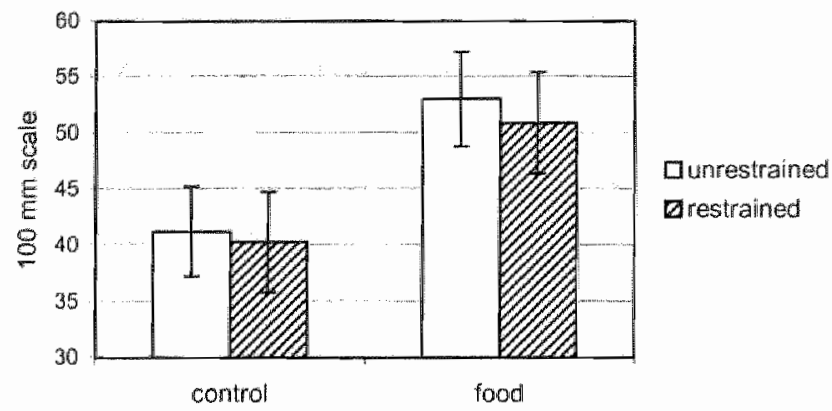

Figure 2. Mean and siandard error of the increase in reported craving after food and control exposure of restrained and whestrained caters.

The third hypothesis from the cue reactivity theory states that an increase in cue reactivity and craving during the exposure is related to an increase in food intake during the taste test. However, the type of exposure (control or food) did not influence food intake, in neither group. No significant difference in food intake between the groups was found. There was also no correlation between craving and food intake. Yet there was a significant correlation between gastric activity during exposure and food intake during the taste test $(r=39, p<.01)$. No other correlation between a physiological meastrement and food intake was found. Mean kcal consumed during the taste test is revealed in Table 2.

Table 2. Mean and standard enror kal comsumed during the taste lest, by the restrained and umrestrained earess, after control or food exposure.

\section{restrained eaters unrestrained eaters}

control exposure $\quad 324(82) \mathrm{kcal} \quad 408(72) \mathrm{kcal}$

food exposure $\quad 227(44) \mathrm{kcal} \quad 300(50) \mathrm{kcal}$


The fourth hypothesis, derived from the cognitive theory, states that during food exposure restrained eaters have more disinhibitive cognitions, leading to an increased food intake during the taste test. Retrospectively, restrained eaters indeed reported more disinhibitive cognitions, than unrestrained eaters did $(F(1,43)=10.2, p$ $<.005)$; however the cognitions were reported as frequently in the food as well as in the control condition. No significant interaction effect was found and there were no significant correlations between the reported cognitions and craving for food as well as food intake.

Explorative, the subjective ratings of emotion (anger, fear and relaxation) before and after the exposure were analysed. There was a significant interaction effect on anger $(F(1,43)=4.4, p<.05)$; restrained eaters reported more anger after control exposure and less after food exposure. Unrestrained eaters reported less anger after control exposure than after food exposure. There were no significant effects of group or exposure on ratings of other subjective states (hunger and nausea). There were also no significant correlations between physiological measurements and subjective ratings.

\section{Discussion}

The aim of the present experiment was to test if the cue reactivity model explains the abnormal regulation of food intake, which is often found in restrained eaters. The theory states that restrained eaters show more reactivity when exposed to food cues (hypothesis 1), experience this reactivity as craving (hypothesis 2) and consequently eat more after the exposure (hypothesis 3). Finally, the widespread cognitive model was tested, which predicts that restrained eaters have more disinhibitive thoughts during exposure to the preload and this leads to an increase in food intake (fourth hypothesis).

In respect to the first hypothesis, unrestrained eaters showed a relative larger increase in food cue reactivity than restrained eaters. Secondly, both groups reported an increase in craving after food exposure, and there was no correlation between craving on one hand and reactivity or food intake on the other hand. The groups also did not differ in food intake. There was however a significant correlation between gastric activity and food intake.

The fourth hypothesis states that restrained eaters have more disinhibitive cognitions during food exposure, leading to counterregulation. However, the restrained eaters did report more disinhibitive cognitions than unrestrained eaters did after food and control exposure. These cognitions did not lead to counterregulation and were not directly related to craving or food intake. Thus, although the restrained eaters did in general have more disinhibitive cognitions, they were not influenced by food exposure and unrelated to food intake.

It was thus found that unrestrained eaters showed a larger increase in cue reactivity than restrained eating subjects. How can we explain this unexpected finding? The increase in heart rate, gastric activity and salivation in normal subjects were also 
found in an earlier study on cue reactivity of unrestrained eaters during food exposure (Nederkoom et al., 2000). Now it appears that gastric activity is indeed related to food intake. Therefore, gastric activity might be considered to reflect a preparation response for food, and interestingly, the zinrestrained subjects did prepare for food intake. It was expected to find restrained eaters to show exaggerated responses. However, they showed no or decreased responses during the food exposure, compared to the control exposure. Opposite responses have also been reported by others: Karhunen Lappalainen, Tammela, Turpeinen and Uusitupa (1997) found a decrease in salivation in obese binge eaters during food exposure, Bulik, Jawson and Carter (1996) found a decrease in salivation in bulimic patients during exposure to binge food, and Rogers, Anderson, Finch, Jas and Gatenby (1999) found a smaller salivary increase in "chocoholics" than in controls, after exposure to chocolate. In the addiction field, it is suggested that opposite physiological reactions serve a compensatory role, thereby diminishing the effect of the drug intake (Siegel, 1989). However, normal subjects who are also conditioned on food intake prepare for food intake by increasing heart rate, gastric activity and salivation, instead of a compensatory decrease (Mattes, 1997; Nederkoorn et at., 2000). It therefore seems unlikely that restrained eaters would show preparations responses in the opposite way.

Rogers et al. (1999) suggest that the food exposure might have caused anxiety, which could have inhibited the salivary reaction, whereas Bulik et al. (1996) found a negative relation between salivation and depression. That exposure to forbidden food can cause defence reactions, is also found by Mauler, Tuschen and Hamm (1997), who found larger startle responses in bulimic patients during food exposure. However, in our experiment, the restrained subjects did not report an increase in anxiety or anger during food exposure, nor did these emotions correlate with the physiological responses. Depression was not measured, therefore the role of emotions cannot completely be ruled out as a determinant of physiological reactivity.

Cognitions might also have played a role of importance. Although disinhibitive cognitions were not related to physiological reactivity or food intake, cognitive strategies are able to influence physiological reactivity. Dawson and Reardon (1969) and Harvey and Wickens (1973) showed that inhibitory instructions ("it is not smart to react physiologically") diminish the skin conductance orienting response, whereas facilitory instructions ("it is very smart to react physiologically") enhance this response. Piacentini, Schell \& Vanderweele (1993) found that restrained eaters showed smaller orienting responses during food exposure than unrestrained eaters did. It thus might be suspected that unrestrained subjects showed physiological reactivity because they, being normal eaters, did not suppress any thought about food intake. Restrained eaters, on the other hand, are supposed to suppress eating-related cognitions. They always try to resirain their intake, in other words, it might be hypothesised that they use cognitive strategies to suppress or block their physiological reactivity. This suggestion would extant the cue reactivity theory: food cues can elicit physiological reactivity which leads to an increased food intake (supported by the correlation found between gastric activity and food intake), but subjects are able to inhibit these reactions by cogmitive suppression. In case the suppression fails, the restrained eaters are expected to overeat. In the present experiment, the restrained eaters might have been successful in suppressing their physiological reactivity, and thereby in restraining 
their food intake. Indeed, we post hoc found a significant positive correlation between scores on the WBSI and the RS $(r=48, p<.001, \mathrm{n}=43)$, suggesting that restraintness in eating and cognitive suppression in general are closely related. However, we did not measure suppression directly, leaving this explanation hypothetically.

Another finding in contrast to predictions of the cue reactivity model was that physiological reactivity was not related to subjective craving, and craving was not related to the amount of food intake. Of course, being in a laboratory and attached to physiological apparatus, can have disturbed feelings of craving and inhibited food intake. It might still be possible that in natural settings, a relation will be found between craving on one hand and physiological reactivity and food intake on the other hand. However, so far we must conclude that no evidence is found that subjective craving plays a role of importance in counterregulation.

In sum, unrestrained eaters showed physiological reactivity during food exposure and over all subjects the gastric activity was related to the amount of food intake afterwards. There was, however, no relationship between subjective craving and food intake. Restrained eaters showed opposite physiological responses, which might result from intervening emotions or the use of cognitive strategies to suppress unwanted reactivity. Because the cognitive suppression hypothesis is post hoc and not tested in the present experiment, it might be a fruitful enterprise for further research to manipulate suppression directly during food exposure and to measure its effects on psychophysiological reactivity as well as on food intake. 


\title{
6. Is cue reactivity a good predictor of binge eating in bulimic women? ${ }^{1,2}$
}

\begin{abstract}
The conditioning model of binge eating predicts that when a person regularly has eating binges, and these binges are reliable preceded by certain cues, these cues become predictors of a binge. Exposure to these cues will evoke conditioned responses, which are supposed to be experienced as an irresistible craving for food and thus make a binge almost inevitable. Evidence for this theory is inconsistent, although an overview is indistinctive because many different cues, measurements, subjects and methods used in various studies. In order to test the main predictions of the theory, 51 women with bulimia nervosa were exposed to individualised food cues, after which they performed a taste test, during which food intake was measured. Their responses were compared to responses of 20 non-eating disordered women. No differences in physiological responses, craving and food intake were found between the groups. Reports of craving and hunger, as well as measures of finger pulse amplitude were related to food intake. The data does support the conditioning theory of eating, albeit not of binge eating. Of special interest is that almost all bulimic women maintained control during exposure and the taste test, only three women showed a miniature binge. Responses of these three women are discussed within the conditioning model of binge eating.
\end{abstract}

\footnotetext{
The authors acknowledge witli gratitude the support of Annie Raven, the Academie Unit (for Cognitive Behaviour Therapy) of the Community Mental Health Center of Madstrichi, Theo van Aarts, Huub Hamers, Peter de Jong and Han Kejzers,

"Nederkoom, C. Meijboom, A. \& Jansen, A. (submitted). Is cue reactivity a good predictor of binge cating in bulimic women?
} 


\section{Introduction}

According to the conditioning model of binge eating, cue reactivity plays an important role in the continuation of eating binges (Jansen, 1998b). The core of the model is that when certain cues, like an emotion, being home alone, the environment or the sight and smell of specific binge food, are repeatedly paired with an eating binge, these cues can predict an upcoming eating binge. During exposure to these cues, the body will prepare for food intake by various responses. These responses are experienced as craving for food and can provoke an eating binge.

Literature provides mixed evidence for this theory. Subjective reports of craving for food or urge to binge did differentiate between women with eating disorders and controls during and after exposure to food cues (Bulik, Lawson \& Carter, 1996; Federoff, Polivy \& Herman, 1997; Karhunen Lappalainen, Tammela, Turpeinen \& Uusitupa, 1997; Staiger, Daw \& McCarthy, 2000). However, the evidence on physiological reactivity to food cues is less forthcoming. During exposure to food, increases in blood pressure and electrodermal activity are found in binge eaters (Vögele \& Florin, 1997). The evidence on salivation is inconsistent, some studies found larger increases of salivation in subjects with abnormal eating behaviour (Klajner, Herman, Polivy \& Chhabra, 1981; LeGoff, Leichner \& Spigelman, 1988; Tepper, 1992; Tuomisto et al., 1999). Larger salivary and heart rate responses were also are found during cue exposure in bulimic women before compared to after treatment (Carter, Bulik, McIntosh, \& Joyce, 2001). Other studies found no difference or even a lower salivary response in eating disordered women (Bulik et al.. 1996; Karhunen et al., 1997, Nederkoorn \& Jansen, 2002; Staiger et al., 2000). Also the evidence on insulin are inconsistent, Teff and Engelman (1996) report a correlation between insulin release and dietary restraint, whereas other studies report no effects of food exposure on insulin release in subjects with eating binges (Karhunen et al., 1997), bulimic women and chronic dieters (Broberg \& Bernstein, 1989).

It is difficult to compare these studies because different kinds of abnormal eating behaviour, exposure cues and techniques as well as physiological parameters are used. Theoretically, it is important to use cues during the exposure that are as close to real cues of individual binge eating episodes as possible. Therefore, studies using individualised food cues are more adequate than studies using standardised food cues. Also, research on subjects with clinical eating binges is preferable over studies with restrained eaters. Restrained eaters are often used as a non-clinical analogue for binge eaters, though the group is very divers. For example, successful dieters and vegetarians also tend to score high on restrained eating questionnaires, although they do not have eating binges and cannot be expected to show exaggerated conditioned cue reactivity. However, there are only a few studies in which subjects with eating binges are exposed to individualised binge food and the results are promising but still inconsistent (Bulik et al., 1996; Carter et al., 2001; Staiger et al., 2000).

In sum, the conditioning model of binge eating predicts that women with eating binges react to food cues with increased physiological responses. These responses are experienced as craving for food. The evidence for this theory is not uniform. Theoretically, the most optimal studies use binge-eating women and expose them to 
individualised binge cues. The number of studies using this methodology is still scarce, and additional research is needed to draw conclusions about the conditioning model of binge eating.

In this experiment women with bulimia nervosa are compared to women without an eating disorder. The subjects are exposed to individualised binge food, or for the control subjects, to favourite food items. During exposure, physical and subjective reactions are measured. Afterwards, the subjects perform a taste test during which caloric intake is measured. It is hypothesised that the bulimic women show increased physiological reactivity to the food cues compared to the controls, report more craving and eat more during the taste test. Also, a relation between physiological reactivity, reports of craving and food intake is expected.

\section{Methods}

\section{Participants}

Fiffy-one patients with bulimia nervosa and twenty women without an eating disorder participated. The patients announced for treatment in the Academic Unit (for Cognitive Behaviour Therapy) of the Community Mental Health Centre of Maastricht. 38 Patients were screened for bulimia nervosa using the SCID-I (Structured Clinical Interview for the Diagnosis) of the DSM-III-R (Spitzer, Williams; Gibbon \& First, 1990), 13 patients using the SCID-I of the DSM IV (First, Spitzer, Gibbon \& Williams, 1995). The 12th edition of the Eating Disorder Examination (Fairburn \& Cooper, 1993) was also administered during their intake. Their mean scores on the subscales of the EDE were: restraint subscale $3.4(\mathrm{SD}=1.1)$, eating concern subscale $2.2(\mathrm{SD}=1.2)$, weight concern subscale $3.6(\mathrm{SD}=1.3)$, shape concern subscale 3.6 $(\mathrm{SD}=1.5)$ and their global score was $3.2(\mathrm{SD}=1.0)$. The mean number of eating binges in the past 4 weeks was $20.4(\mathrm{SD}=18.2)$. The mean BMI of the bulimics was $22.6(\mathrm{SD}=2.3)$ and mean age was 24.8 years $(\mathrm{SD}=6.4)$.

The control subjects were selected from first year students, who completed several questionnaires, including a Dutch translation of the Restraint Scale (RS, Herman \& Polivy, 1980). Only low restraint subjects with scores below 12 were asked to join the experiment. Their mean score on the RS was $8.6(\mathrm{SD}=2.2)$. Mean BMI was $22.8(\mathrm{SD}=1.5)$ and mean age 20.2 years $(\mathrm{SD}=2.0)$. The control women were significantly younger than the bulimics $(t(69)=4.6, p<.01)$.

\section{Measurements}

Subjective states (hunger, tension, craving for food and depression) were scored on visual analogue scales (VAS), ranging from 0 (e.g. not at all hungry) to 100 (e.g. very hungry). 
Physiological measurements were all sampled with $1000 \mathrm{~Hz}$. Heart rate, finger pulse amplitude, skin conductance and temperature were measured. Three $\mathrm{Ag}-\mathrm{AgCl}$ electrodes measured heart rate; two attached over the heart region and a reference electrode was placed on the back of the subject. $R$-waves were detected off-line with a template matching procedure, and beats per minute were calculated. Finger pulse amplitude was measured by a photoplethysmograph, placed by a clip on the middle finger of the non-dominant hand. Skin conductance was measured with three $\mathrm{Ag}-\mathrm{AgCl}$ electrodes, placed on middle and ring finger of the non-dominant hand, the reference electrode was placed on the back of this hand. Temperature was measured by a thermistor, placed in the armpit.

The amount of calories eaten during the taste test was calculated by weighting the bowls with food before and after the taste test, multiplying the difference by the caloric value of the specific food.

\section{Procedure}

During the intake sessions, the bulimic patients were asked to list the top four of their most preferred and most eaten binge foods. The control women are asked to list four of their most favourite food items. The participants were instructed to eat $100 \mathrm{kcal}$ two hours before the experiment, in order to diminish individual difference in hunger and satiety. Each subject was run individually. After entering the laboratory, first another task (a Stroop task ${ }^{3}$ ) was done. Afterwards, the electrodes were attached and signals were checked. The subject was told that physiological reactivity to food would be measured. In front of the participant a round table was turning slowly, and paused for a few seconds every quarter of the plateau. The participant was instructed to sit quietly and relaxed. She filled in her subjective states on the scales. A baseline measurement of 1 minute was made. Then four plates, each filled with large amounts of the personal binge food were placed on the turning table, right under the nose of the participant. (see Picture 1).

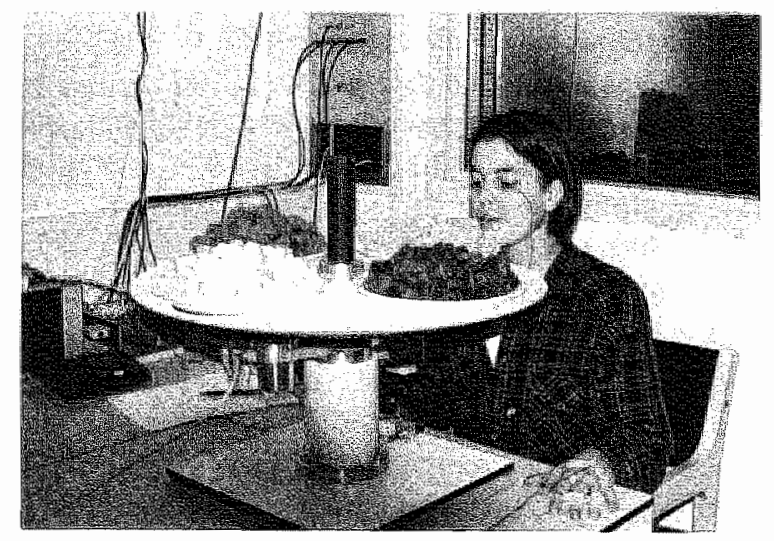

Picure 1. Control subject exposed lo food. while measurements are made.

Data will be presented elsewhere 
The subject was instructed to smell the food. Her subjective states were scored again and a 10 minutes exposure time started. After 5 minutes the exposure was interrupted, the subjects scored their subjective states and the exposure continued. At the end of the exposure, the subjects scored their subjective states for the fourth and last time. After that, the experimenter presented a small amount (around 5 gram) of binge food on a plate. The subject was instructed to eat it the small preload. Afterwards, the subject was instructed to taste the food, used during the exposure. She received a questionnaire about the taste of the food and was allowed to eat as much as she wanted. The experimenter told her that she understood how difficult this task was and that the subject was allowed to visit the toilet afterwards (giving the possibility to vonit, brush her teeth and take some sugarless chewing gum). Then the subject was left alone for ten minutes.

\section{Analyses}

The data were analysed with ANOVA for repeated measures. Separate ANOVA's are presented for the effects of the exposure and the effects of the taste test. Due to apparatus failure or artefacts, the physiological data was not complete. For skin conductance, data of 11 subjects ( 6 control and 5 bulimia) was missing, for finger pulse amplitude, data of 5 bulimic subjects was missing, and for temperature data of 6 subjects was missing (all bulimia). Because the temperature measurements could not be calibrated correctly, only change scores within subjects are analysed. Of seven bulimic subjects, no physiological data was collected during the taste test. Another three bulimic subjects performed the taste tests for 5 minutes instead of 10 minutes; of these subjects the mean scores on physiological data over these five minutes are included in the analyses.

Because it is uncertain at which moment the effects of the exposure is at its top, and this timing can vary across subjects and physiological parameters, for each subject and parameter, the mean highest response over a 1 minute period within the ten minutes exposure time is selected ${ }^{4}$.

For the effect of the taste test on the physiological parameters, the mean highest response over five minutes was selected.

\section{Results}

\section{Exposure}

Exposure to binge food led to a significant increase in heart rate, finger pulse amplitude and skin conductance over all subjects (table 1). No effect of the exposure

\footnotetext{
The same analyses are done using the mean responses over the 10 minutes exposire fime, and over the forst and the last 5 minutes exposure. The resills from these analyses are not substantial different.
} 
on temperature was found. No differences between groups or differential effects of the exposure on the groups were found on any of the physiological measurements.

Exposure also led to a significant increase of subjective ratings of craving, hunger, depression and arousal (table 1). The bulimic women reported lower ratings of craving and higher ratings of depression during both the baseline and exposure period. No differential effects of the exposure on the groups were found on subjective ratings.

Table 1. Mean and standard deviation (SD) of the baseline and the highest score during exposure and statistical effects, on heart rate, finger pulse amplitude, skin conductance. temperature, craving, hustger, arousal and depression.

\begin{tabular}{|c|c|c|c|c|c|}
\hline & $\begin{array}{l}\text { bullimics } \\
\text { mean (SD) }\end{array}$ & $\begin{array}{l}\text { controls } \\
\text { mean (SD) }\end{array}$ & effect & $F$ & $p$ \\
\hline $\begin{array}{l}\text { heart rate } \\
\text { baseline } \\
\text { exposture }\end{array}$ & $\begin{array}{l}73.6(10.4) \\
76.7(11.8)\end{array}$ & $\begin{array}{l}74.1(9.6) \\
77.7(8.7)\end{array}$ & $\begin{array}{l}\text { time } \\
\text { group } \\
\text { time group }\end{array}$ & $\begin{array}{l}F(1,69)=31.2 \\
F(1,69)=0.07 \\
F(1,69)=0.1\end{array}$ & $\begin{array}{l}<001 \\
\mathrm{~ns} \\
1 \mathrm{nS}\end{array}$ \\
\hline $\begin{array}{l}\text { finger pulse } \\
\text { baseline } \\
\text { exposure }\end{array}$ & $\begin{array}{l}5.6(2.1) \\
7.5(3.0)\end{array}$ & $\begin{array}{l}6.5(3.7) \\
8.0(4.1)\end{array}$ & $\begin{array}{l}\text { time } \\
\text { group } \\
\text { time group }\end{array}$ & $\begin{array}{l}F(1,64)=28.3 \\
F(1,64)=0.79 \\
F(1,64)=0.45\end{array}$ & $\begin{array}{l}<001 \\
\mathrm{nS} \\
\mathrm{ns}\end{array}$ \\
\hline $\begin{array}{l}\text { skin cond alct. } \\
\text { baseline } \\
\text { exposure }\end{array}$ & $\begin{array}{l}3.6(1.7) \\
4.4(2.2)\end{array}$ & $\begin{array}{l}4.1(1.5) \\
4.8(1.6)\end{array}$ & $\begin{array}{l}\text { time } \\
\text { group } \\
\text { tinte * group }\end{array}$ & $\begin{array}{l}F(1,58)=24.6 \\
F(1,58)=0.67 \\
F(1,58)=0.01\end{array}$ & $\begin{array}{l}<.001 \\
\mathrm{~ns} \\
\mathrm{~ns}\end{array}$ \\
\hline $\begin{array}{l}\text { temperature } \\
\text { exposure minus } \\
\text { baseline }\end{array}$ & $.00227(.13)$ & $.041(.007)$ & group & $f(1,63)=1.3$ & ns. \\
\hline $\begin{array}{l}\text { cuaving } \\
\text { baseline } \\
\text { cxposure }\end{array}$ & $\begin{array}{l}18.5(21.5) \\
55.9(30.5)\end{array}$ & $\begin{array}{l}30.7(21.0) \\
66.7(20.2)\end{array}$ & $\begin{array}{l}\text { time: } \\
\text { group } \\
\text { time } \text { group }\end{array}$ & $\begin{array}{l}f(1,69)=105 \\
F(1,69)=4.3 \\
F(1,69)=0.04\end{array}$ & $\begin{array}{l}<.001 \\
<.05 \\
n, 5\end{array}$ \\
\hline $\begin{array}{l}\text { launger } \\
\text { buseline } \\
\text { oxposure }\end{array}$ & $\begin{array}{l}23.5(25.0) \\
46.2(33.7)\end{array}$ & $\begin{array}{l}33.8(28.2) \\
51.1(27.3)\end{array}$ & $\begin{array}{l}\text { time } \\
\text { group } \\
\text { time * group }\end{array}$ & $\begin{array}{l}f(1,69)=29.6 \\
f(1,69)=1.3 \\
f(1,69)=0.55\end{array}$ & $\begin{array}{l}<001 \\
n s \\
n s\end{array}$ \\
\hline $\begin{array}{l}\text { arousal } \\
\text { buseline } \\
\text { exposure }\end{array}$ & $\begin{array}{l}31.4(26.7) \\
49.9(30.8)\end{array}$ & $\begin{array}{l}22.4(19.1) \\
41.1(23.4)\end{array}$ & $\begin{array}{l}\text { time } \\
\text { group } \\
\text { time }{ }^{\text {** }} \text { group }\end{array}$ & $\begin{array}{l}F(1,69)=52.3 \\
F(1,69)=1.8 \\
F(1,69)=0\end{array}$ & $\begin{array}{l}<001 \\
n s \\
\text { ns }\end{array}$ \\
\hline $\begin{array}{l}\text { depression } \\
\text { baselinc } \\
\text { exposure }\end{array}$ & $\begin{array}{l}29.1(27.4) \\
44.3(31.0)\end{array}$ & $\begin{array}{l}12.3(15.6) \\
16.9(20.7)\end{array}$ & $\begin{array}{l}\text { time } \\
\text { group } \\
\text { time group }\end{array}$ & $\begin{array}{l}F(1,69)=9.9 \\
F(1,69)=12.4 \\
F(1,69)=2.8\end{array}$ & $\begin{array}{l}<.01 \\
<.01 \\
\mathrm{~ns}\end{array}$ \\
\hline
\end{tabular}


Taste test

During the taste tests, no difference in caloric intake between groups was found (table 2). Interestingly, the three bulimic patients who said on forehand that they were only willing to perform the taste tesi for 5 minutes, ate significantly more then the other bulimic patients during 10 minutes $(l(46)=3.1, p<.01)$. It therefore appeared that these three women were afraid of losing control over their eating behaviour and indeed started a real eating binge. Although the subgroup of these three women is too small to perform meaningful statistical tests, it semed interesting to explote the physiological and subjective responses of these subjects during the food exposure. Or all responses, the effects of the exposure mimus the baseline are depicted for the group and for the three individuals (Figure 1). It appeared that besides eating more, the three subjects reported more depression and on average, more craving and hunger, although the subject who ate the most (the last subject in the row in the figures) reported the least craving and hunger. One subject reported a large increase in arousal, the other two didn't. Of the physiological responses it seems that these subjects had smaller increases in finger pulse amplitude than the group. No meaningful pattern can be distinguished on the other measurements. Possible implications for the conditioning model of binge eating are described in the discussion section.
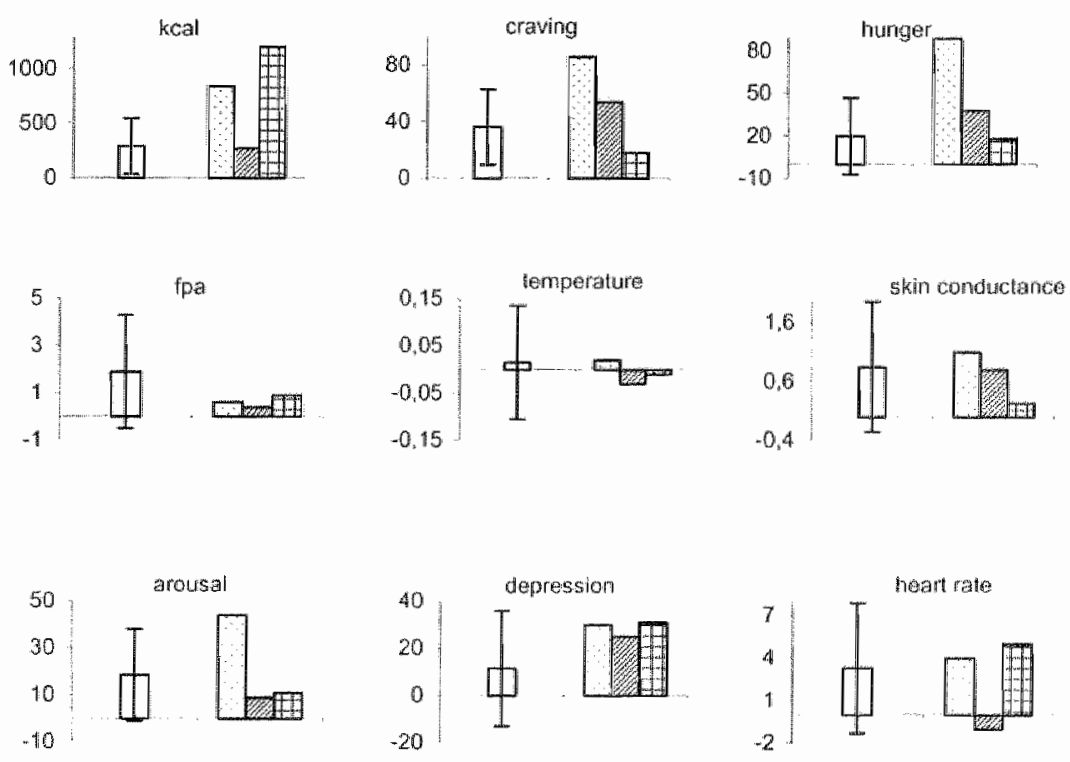

Figure 1. Mean and SD of the group (left bary and the individual scores of the three bulwics (righ bars) on caloric intake and increases in craving, hunger, arousal, depression, hoart rate, finger pulse ampliude (FPA), femperature and skin conductance during the exposure period, compared to the baseline. 
During the taste test, heart rate of all subjects was significantly elevated and finger pulse amplitude and skin conductance were significantly decreased, compared to the exposure periodl (table 2). No differences between groups or differential effects of the taste test on the groups were found.

Table 2. Mean scores and standard deviation (SD) during the baseline and the taste test, and statistical effects on: consumed calories, heart rate, finger pulse amplinde, skin conductance and temperature.

\begin{tabular}{|c|c|c|c|c|c|}
\hline & $\begin{array}{l}\text { bullimics } \\
\text { mean (SD) }\end{array}$ & $\begin{array}{l}\text { controls } \\
\text { mean (SD) }\end{array}$ & effect & $F$ & $p$ \\
\hline kacal & $315(289)$ & $316(274)$ & group & $t(64)=.01$ & $\mathrm{~ns}$ \\
\hline $\begin{array}{l}\text { lueart rate } \\
\text { exposture } \\
\text { taste test }\end{array}$ & $\begin{array}{l}76.4(12.1) \\
80.6(11.5)\end{array}$ & $\begin{array}{l}77.7(8.7) \\
81.6(10.1)\end{array}$ & $\begin{array}{l}\text { time } \\
\text { group } \\
\text { time * groups }\end{array}$ & $\begin{array}{l}F(1,62)=37.0 \\
F(1,62)=0.15 \\
F(1,62)=0.05\end{array}$ & $\begin{array}{l}<.001 \\
n s \\
n s\end{array}$ \\
\hline $\begin{array}{l}\text { finger pulse } \\
\text { baseline } \\
\text { tuste test }\end{array}$ & $\begin{array}{l}7.5(3.1) \\
6.5(3.0)\end{array}$ & $\begin{array}{l}7.5(3.6) \\
6.4(3.2)\end{array}$ & $\begin{array}{l}\text { tirle } \\
\text { group } \\
\text { time group }\end{array}$ & $\begin{array}{l}F(1,57)=24.6 \\
F(1,57)=0.0 \\
f(1,57)=0.03\end{array}$ & $\begin{array}{l}<.001 \\
\text { nas } \\
\text { ns }\end{array}$ \\
\hline $\begin{array}{l}\text { skin conduct. } \\
\text { baseline } \\
\text { laste test }\end{array}$ & $\begin{array}{l}4.5(2.2) \\
3.8(2.0)\end{array}$ & $\begin{array}{l}4.8(1.6) \\
4.4(1.5)\end{array}$ & $\begin{array}{l}\text { time } \\
\text { group } \\
\text { lime group }\end{array}$ & $\begin{array}{l}F(1,54)=19.4 \\
F(1,54)=0.58 \\
F(1,54)=0.54\end{array}$ & $\begin{array}{l}<.001 \\
\mathrm{~ns} \\
\mathrm{~ns}\end{array}$ \\
\hline $\begin{array}{l}\text { temperature } \\
\text { taste test minus } \\
\text { baseline }\end{array}$ & $-.053(.16)$ & $.077(.12)$ & group & $r(1,63)=0.83$ & ns \\
\hline
\end{tabular}

Relations between subjective and physiological reactivity and caloric intake

The highest report of craving during the exposure was significant related to caloric intake afterwards $(r=36, p<.01)$. Finger pulse amplitude was also related to caloric intake: the subjects with smaller increases in finger pulse amplitude compared to the baseline ate more $(r=-.26, p<.05)$.

Craving and finger pulse amplitude during exposure were also related: subjects with the smaller increases in finger pulse amplitude compared to the baseline reported the higher craving $(r=-.29, p<.05)$. Furthermore, subjects with smaller increases in finger pulse amplitude compared to the baseline reported more hunger $(r=-.26, p<$ $.05)$. 
Physiological changes during the taste test were also related to caloric intake: subjects with higher increases in heart rate during the taste test ate more $(r=27, p<$ .05) and subjects with smaller increases in finger pulse amplitude ate more $\left(y^{*}=-37, p\right.$ $<.01)$.

\section{Discussion}

In the present experiment bulimia nervosa patients and a control group were exposed to their individual binge food (bulimics) or highly preferred food (controls). During exposure, physical and subjective cue reactivity was measured. Afterwards, the subjects completed a taste test, during which they were invited to eat as much as they liked. Meanwhile, physiological responses were measured. Later, caloric intake was calculated. It was hypothesised that the bulimic women would report more craving and show increased physiological responses during the exposure, compated to the control group. Furthermore, it was expected that the bulimic women would eat more during the taste test.

However, both groups reported more craving during the exposure period compared to the baseline. Over the entire experiment, the bulimic women reported less craving than the controls. Also, in both groups heart rate, finger pulse amplitude and skin conductance increased during the exposure, but no differences between the groups were found. Finally, no differences in caloric intake were found between the groups. The bulimic women did report more depression during the experiment and both groups got more depressed, aroused and hungry during the exposure. An additional hypothesis was that cue reactivity and caloric intake during the taste test were related to each other. Indeed, the amount of food eaten after the exposure was positively related to craving and negatively to increases in finger pulse amplitude (fpa) during the exposure. Also, increases in fpa were negatively related to craving. Food intake itself decreases the finger pulse amplitude, because activity in the gastrointestinal tract demands more blood supply (Nederkoom of al., 2000). Also in this experiment, linger pulse amplitude decreased during the taste test compared to the exposure period. It is therefore expected that preparation for food will be accompanied by a decrease in fpa. However, it is possible that other factors, like relaxation or wamth, have an opposite effect on fpa. In this case, two opposite processes determine the net effect on fpa. The fact that a smaller increase is fpa is correlated to a larger food intake and a larger craving for food can be explained by a relative increase of preparation responses. Together this indicates that the conditioned responses to food cues do determine, at least partly, food intake. This supports the conditioned theory of earing, albeit not of binge eating.

An important conclusion of this experiment is that the exposure to individual binge food hardly evoked increased conditioned responses and craving in the bulimic women, compared to the control women, and the bulmics were able to control their food intake during the taste test. Of the group bulimics, three individuals refused to perform the taste test. Yet, the experimenter convinced them to complete the taste test 
in five minutes instead of ten ninutes. Surprisingly, on average these three bulimic women ate more during this shorter period. It seemed that these bulimics lost control over their eating behaviour and started an eating binge and were afraid of this before they started eating. An interesting question is if these eating binges were preceded by increased physiological reactivity and craving. Although statistical testing was not possible because of the small number of subjects, depicting the means revealed that on average, the three bulimics reported larger increases in craving and hunger during exposure, although the one subject, who ate the most, reported the smallest increase in craving and hunger. More obwious is that all three bullimics reported large increases of depression. Furthermore, the three bulimics had smaller increases in finger pulse amplitude; no clear picture can be derived from the other physiological parameters. This last finding is interesting, because smaller increases in fpa and higher reports of craving were related to larger amounts of caloric intakes. It appears that for these three bulimics the conditioning model of binge eating is applicable, the subjects had larger conditioned responses (a smaller increase is interpreted as a relative increase of the preparation response), more craving (two out of three) and ate more. However, the reader must keep in mind that these conclusions are based on the means of three subjects, and not founded on statistical tests.

The question raises why the other bulimic women did not show increased conditioned reactivity, compared to the control women. It can be argued that the subjects were in a strange situation during the exposure, which might have prevented conditioned responses. Food cues alone might not be sufficient enough to evoke physiological responses or craving for food. The presence of the experimenter, although in another room, and being attached to several apparatus, might have induced feelings of shame or awkwardness, thereby inhibited urges to binge. Perhaps the bulimic women actively tried to control their food intake and urge to binge by suppressing thoughts and craving for food. The lower craving scores of the bulimics during the baseline support this. However, most other studies using the same procedure do find larger increases in craving or urge to binge in binge eaters. Results on physiological reactivity are inconsistent, but nevertheless indicate that it is possible to elicit conditioned responses to food cues in laboratory settings.

Another explanation for the absence of increased reactivity in the bulimic women is that they reported higher feelings of depression than the control women did. These feelings can have counteracted or masked the reactivity to the food cues. Bulik. et al. (1996) found a negative relation between salivation and depression, and this linding supports the explanation that the feelings of depression might have diminished reactivity. However, the three women who had an eating binge reported higher levels of depression and they did show conditioned reactivity.

Altogether two possibilities remain. First, bulinic women do have increased conditioned reactivity and craving to binge cues in real life, but these binge cues are not presented well enough in our study and failed to evoke reactivity and thereby binge eating, Only three bulimics were identified, who did binge and indeed they appeared to show altered conditioned reactivity. This suggests that when bulimic women are confronted with their personal binge cues in real life, conditioned responses and

\footnotetext{
\$ The comelation between finger pulse amplitude and caloric intake remains significant when these three women are excluded from the analyses.
} 
craving for food might be elicited and an eating binge can be the result of it. In order to lest this possibility, physiological responses should be measured continuously for a period in which the subject has naturalistic eating binges. Although this option has large practical problems, and the act of measuring can always interfere with the normal processes, it might be the only way to test the conditioned theory of binge eating.

The second option is that the conditioned theory of binge eating is not correct. Perhaps the eating binges are not frequent enough or do not always follow a strict pattern, which can prevent conditioning. Also, the conditioning that already exists in binge eaters because of their experience with food throughout their lives may prevent an additional conditioning to binge cues. In this case, binge eating must be explained by alternative mechanisms. For normal eating, the conditioning theory seems to fit very well. Normal people react to the sight and smell of palatable food with conditioned responses. These responses influence food intake and determine to a certain extent how much someone will eat. 


\title{
7. General discussion
}

\begin{abstract}
In this thesis, the conditioning model of binge eating is studied. This model is founded on three important assumptions. First, when cues are reliable predictors of eaing binges, exposure to these cues evokes physiological reactivity. Second, this reactivity is experienced as craving for food and third, increases in physiological reactivity and craving results in binge eating. The assumptions are tested in several studies, but no support has been found in restrained eaters and bulimic women. However, normal eating did fit in the conditioning model. The implications of the findings for theoretical, methodological and therapeutic issues are discussed.
\end{abstract}




\section{Summary of the data}

In this thesis the conditioning model of binge eating is studied. This model is founded on three important assumptions. First, when cues are reliable predictors of eating binges, exposure to these cues evokes physiological reactivity. Second, this reactivity is experienced as craving for food and third, increases in physiological reactivity and craving results in binge eating. These assumptions are tested in several studies.

In the first part of this thesis, methods for measuring salivary reactivity to food are examined. In the first study (chapter 2), females are exposed to saliva provoking stimuli, while the salivary response was measured in different ways. The cotton roll method was used as control method, three rolls are inserted in the mouth of the subject and weight increase of the rolls is determined afterwards. Measuring the frequency of swallows by electromyography, as index of salivation production, was the experimental method. It appeared that both methods could differentiate between the salivary response on diverse stimuli and the scores of both methods were correlated to each other. In conclusion, counting swallows measured by electromyography appeared to be a valid and reliable method to measure the salivary response. In the second study (chapter 3), both males and females are exposed to salivary provoking stimuli. Again, the salivary response is measured by the cotton roll method and the swallow method, and this time a third method is added: measuring electrophysiological activity of the parotid gland. Results showed again that the cotton roll method and the swallow method distinguished the stimuli and the scores of the methods were related; however, the parotid method could neither differentiate between the stimuli, nor was related to the other methods. The final conclusion of the first part of this thesis is that both the cotton roll method and the swallow method are useful, the parotid method isn't. Experimental needs will determine which of the two methods is more appropriate. When a laboratory with electrophysiological apparatus is available and for the purpose of the experiment it is important not to influence appetite, counting swallows is recommended. When the measurements are made outside a laboratory setting or the subjects cannot sit quietly and relaxed, the dental roll method is recommended.

In the second part of this thesis, the conditioning model of binge eating was tested. First, the reactivity of normal subjects to food cues and an imitation-eating binge was examined (chapter 4). It appeared that the normal subjects responded during the exposure to food cues and during and after the eating binge with physiological adjustments. The cue reactivity matched the binge reactivity, in that the physiological variables changed in the same direction. This means that the cue reactivity might be interpreted as gearing up the body, in order to digest the upcoming food as well as possible. Significant correlations between dietary restraint and blood pressure, between blood pressure and craving, and between craving and food intake were found. These relations support the conditioning theory of eating in normal subjects.

In the subsequent study, low and high restraint eaters were exposed to food cues or control cues and completed a taste test afterwards (chapter 5). It was hypothesised that the restrained eaters would show more physiological reactivity, more craving and eat more, compared to the unrestrained eaters. However, it appeared that contrary to these expectations, restrained eaters showed smaller physiological reactivity (heart 
rate, salivation and gastric activity) to the food cues than the unrestrained eaters. Both groups reported more craving during food exposure, whereas food intake was not influenced by type of exposure or group. There was a significant correlation between gastric activity and food intake over all subjects. These results do support the conditioning model of eating in unrestrained eaters, they showed increased physiological responses and craving during exposure to food cues compared to the control cues, and physiological reactivity was related to food intake. The restrained eaters however, showed less cue reactivity, contrary to the expectations. Several explanations are suggested; first it is possible that the restrained eaters are successful dieters, have less experience with candy and therefore show less conditioned physiological reactivity. In this case, the restrained eating would be a poor model for binge eating. Second, it is possible that the restrained eaters controlled and suppressed their reactivity during the food exposure and the taste test by using cognitive strategies. Indeed, restraintness was correlated to a style of cognitive suppressing unwanted thoughts. However, this option should be tested experimentally and till now it must be concluded that the conditioning model of binge eating received no support.

In the final study (chapter 6), women with bulimia nervosa were exposed to their personal binge food and performed a taste test afterwards, in which caloric food intake was measured. Their responses were compared to normal women, who were exposed to their favourite food items. It was hypothesised that the bulimic women would show more physiological reactivity during the exposure, report more craving and eat more during the taste test. However, no differences between groups in physiological responding were found. Both groups showed an increase in heart rate, finger pulse amplitude and skin conductance. Overall, the bulimic women reported less craving and more depression, but no differential effect of the exposure was found. Also, no differences in caloric intake were found. The amount of food eaten during the taste test was positively related to craving and negatively to increases in finger pulse amplitude (fpa) during the exposure. Also, increases in fpa were negatively related to craving. Smaller increases in fpa can be interpreted as a relative increase of preparation responses. Together this indicates that physiological responses to food cues and craving do determine, at least partly, food intake. This supports the conditioned theory of eating, albeit not of binge eating. An important conclusion of this experiment is that exposure to individualised binge food did not induce an eating binge in the bulimic women, they kept control over their eating behaviour. However, there were three women who didn't want to perform the taste test, but were persuaded to do so for a shorter period. Surprisingly, these three women ate more during this shorter period than the other women did during a longer interval. The means of the scores of these three subjects revealed that they were more depressed, reported more craving and hunger and showed a smaller increase in finger pulse amplitude. It appeared therefore, that for these three bulimic women the conditioning model of binge eating is applicable. However, these conclusions are based on the means of three subjects, and not founded on statistical tests.

Overall, the findings of the studies in this thesis do support the conditioning model of eating. However, the support for the explanation of binge eating is not convincing. 


\section{Tenability of the assumptions of the conditioning model of binge eating}

Most important findings reported in this thesis do not support the conditioning theory of binge eating. For a critical examination of the theory, the implications of the findings for the three assumptions of theory will be discussed.

\section{Exposure to conditioned cues evokes physiological reactivity.}

It is expected that this reactivity will be enhanced in binge eaters compared to normal subjects. However, restrained eaters showed less physiological reactivity than the unrestraned eaters when exposed to palatable food (chapter 5). Furthermore, no significant differences between bulimic women and controls were found in physiological reactivity during exposure to personal binge food (chapter 6). In sum, the eating disordered women did not show enhanced cue reactivity. How can these results be explained? It is possible that the restrained women were successful dieters and had less experience with candy than the unrestrained eaters, therefore showing less reactivity. However, it does not seem reasonable that bulimic patients have less experience with their personal binge food than controls with their favourite food items. Another explanation can be that both the restrained eaters and the bulimic patients tried to suppress reactivity and craving during the food exposure, in order to keep control over their eating behaviour and avoid, in their eyes, shameful responses. Following this reasoning, the restrained eaters succeed in this even better than the bulimic women did, because they showed less reactivity than the controls, whereas the bulimic women showed the same reactivity as the control women. This difference in success can be explained by the use of more tempting personal binge food in the experiment with the bulimics, compared to the general palatable food in the experiment with the restrained eaters. Also, bulimic women might be less successful in suppressing and controlling their responses to binge cues, which is at the core of their disorder.

In normal subjects, conditioned reactivity is found repeatedly. Subjects showed larger salivary responses during exposure to lasagne (chapter 2 and 3 ) and responded with cardiovascular activity, temperature, gastric activity, salivation and skin conductance to exposure to personal palatable food (chapter 4). Also, unrestrained subjects responded to exposure to food compared to soap with increases in salivation, gastric activity and heart rate (chapter 5). Finally, both bulimics and controls responded during food exposure with an increase in heart rate, finger pulse amplitude and skin conductance (chapter 6). In sum, no enhanced reactivity is found in eating disordered women. In normal women and for normal eating behaviour however, the first assumption received profound support.

\section{Physiological reactivity to food cues is experienced as craving for food.}

Indeed, some relations between physiological reactivity and craving were found. In normal subjects (chapter 4), blood pressure was related to craving and calculated over both bulimic women and controls, finger pulse amplitude was related to craving 
(chapter 6). Of course, these are no causal rellations and the interpretation that physiological responses are actually experienced as craving is still tentative. However, it is apparent that the concepts are at least interrelated.

No increased reactivity is found in the eating disordered women compared to the control women, and therefore no physiological basis for increased craving. Indeed, both the restrained eaters and the bulimic women did not report more craving than the control women and when craving is the result of cue reactivity, this might be exactly what can be expected. To be short, if no enhanced physiological reactivity and craving is evoked in eating disordered women, the second assumption cannot be confirmed or falsified.

\section{Increases in physiological responses and craving lead to binge eating.}

Several significant relations confirm this assumption. In normal subjects (chapter 4), craving was related to food intake. Calculated over restrained and unrestrained eaters, gastric activity was related to food intake (chapter 5) and calculated over bulimic and control women, finger pulse amplitude and craving were related to food intake (chapter 6). The fact that no increased food intake was found in restrained eaters (chapter 5) or bulimic women (chapter 6) can be explained by the failure to induce enlarged cue reactivity and craving in these women. Again, cue reactivity and binge eating must be induced in order to be able to investigate the relation between them.

In sum, for all subjects, the conditioning model of eating seems to fit very well. The subjects show reactivity during exposure to food cues, which can be interpreted as gearing up the body, in order to digest the coming food as well as possible. Cue reactivity is related to craving and both cue reactivity and craving is related to food intake. In spite of this, no differences between normal subjects and eating disordered subjects are found on physiological reactivity or craving, and no evidence that binge eating is influenced by physiological reactivity or craving.

\section{Methodological issues}

In this thesis, no convincing evidence is found for the conditioning theory of binge eating. Two possibilities are open: first, there is no such evidence and the conditioning theory of binge eating is not correct. Second, the research in this thesis failed to detect such evidence, because of methodological or experimental limitations. To evaluate the validity of the second option, possible shortcomings are discussed.

A first problem can be a lack of statistical power. Only one study used subjects with regular clinical eating binges (chapter 6). Another study used restrained eaters, which might not be an appropriate model for binge eaters. More research with subjects with clinical eating binges could strengthen the conclusions of this thesis. The reason why this kind of research was linited has practical reasons. Although comprehensive cooperation with the Community Mental Health Center of Maastricht exists, it is difficult to find women with regular clinical eating binges, who are suitable and 
willing to participate in scientific research. In fact, it took seven years to collect the data of fifty-one women with bulimia nervosa, as described in chapter 6. Still, more research on women with clinical eating binges is preferable.

A second shortcoming of the cue exposure paradigm is that it is possible that the cues presented in a laboratory do not match the cues during a natural eating binge well enough. Although in the study with bulimic women, personal binge food is used, important binge cues can have been omitted during the exposure. For example, context is an important factor in conditioning and it also appeared from studies on eating binges that they mostly occur when the subject is alone (Waters, Hill \& Waller, 2000). In the studies in this thesis, the subjects were alone in the laboratory room, but the subjects were attached to electrodes and apparatus and they must have felt observed. Perhaps these differences with the natural binge settings made the cues too weak to elicit conditioned responses. To test this hypothesis, measurements before and during a spontaneous eating binge in the natural environment should be made. However, besides practical difficulties, one must be aware that the act of measuring can always influence the process one wants to measure. If a subject registers craving for food and knows that physiological measurements are made, this can prevent natural responses. Maybe a perfect method to measure cue reactivity in binge eaters does not exist. Although one can try to optimise the experimental setting, imperfect methods cannot be a lasting excuse for not finding what is expected.

Another important issue that must be addressed is the selection of physiological parameters that are measured during the exposure. If cue reactivity can be interpreted as physiological preparation, related responses should be measured. In normal subjects, preprandial changes in blood flow, metabolic rate, gastric motility, salivation, insulin and blood sugar are related to optimal digestion of food (Mattes, 1997; Nederkoorn, 2000, Woods, 1991). Indeed, a selection of these parameters is used in different studies in this thesis. Some parameters are omitted in these studies, for practical or theoretical reasons. For example, blood glucose and insulin concentrates are not measured. Not only are the measurements invasive and laborious, in the literature effects of eating disorders on glucose and insulin responses to food exposure were scarcely reported (Broberg \& Bernstein, 1989; Johnson, Jarell, Chupurdia \& Williamson, 1994; Karhunen, Lappalainen, Tammela, Turpeinen \& Uusitupa, 1997; Teff \& Engelman, 1997). Although alternative measures might be interesting, there is no reason to think that different indices would reveal different results. It is not plausible that the body only prepares with digestive enzyme secretion and not with related changes in salivation or gastric activity. To be short, although different indices of physiological preparation for food can be measured, the measurements used are adequate and sufficient.

A different option is that the conditioned reactivity cannot be interpreted as preparation for food. It is suggested that the reactivity is emotional in nature (Vögele \& Florin, 1997). Changes in salivation, heart rate, blood pressure or gastric activity would be signs of changes in emotionality. A specific parameter for arousal is skin conductance (Bradley, 2000). Indeed, skin conductance increased during the exposure in normal subjects (chapter 4) and both in normal and bulimic women (chapter 6). No differences between restrained and unrestrained eaters (chapter 5) or bulimic women and control women (chapter 6) were found on skin conductance. However, neither skin 
conductance nor any of the other physiological parameters were related to subjective indices of emotionality, like anger, fear, depression or arousal. This indicates that exposure to food items does increase arousal in subjects, but it is highly unlikely that all these physiological responses are emotional in nature. Because multiple relations were found between physiological parameters and ratings of craving and caloric intake, the interpretation of cue reactivity as preparation for food appears to be more valid.

However, from another theoretical viewpoint, the interpretation of cue reactivity as preparation for food is questioned. According to the conditioned incentive model of Stewart, de Wit \& Eikelboom (1984), it is not the physiological effect of the drug that is the unconditioned response, but the experienced positive affective aspects of the drug. Applied to binge eating, during an eating binge the subject experiences the positive hedonic effects of the food. When cues come to predict an eating binge, exposure to these cues elicits anticipation on these incentive aspects of food and elicits a mental hedonic representation of the food (Zellner \& Edwards, 2001). For example, the binge eater can almost taste the chocolate, feels it melt in her mouth and feels the sensation of the creamy substance against her tongue and palate, during exposure to binge predicting cues. According to the theory, this image or representation increases craving and can lead to actions to obtain the food and in the end to an eating binge. Physiological responses are a possible consequence of craving for food and not the originator. The effects of cue exposure according to the conditioned incentive theory and to the conditioning model of binge eating are depicted in Figure 1.

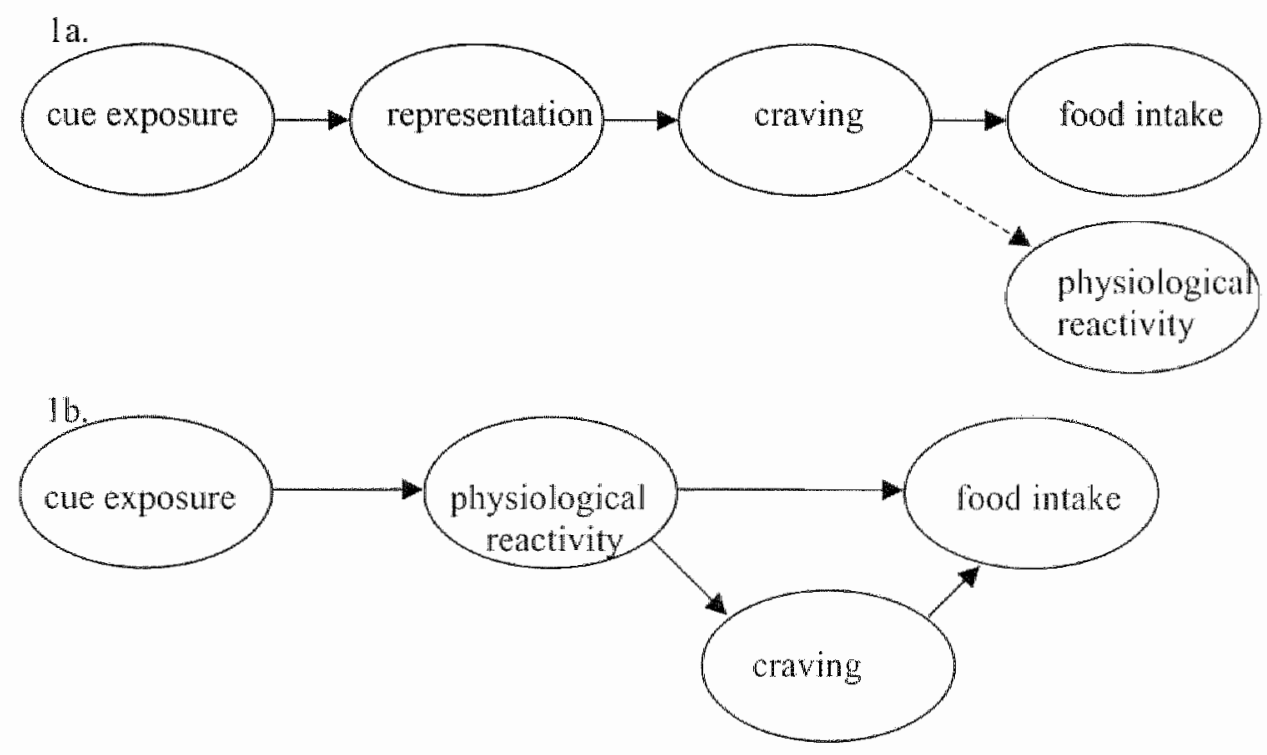

Figure 1. Effects of cue exposure on craving, physiological responses and food intake according to the conditioned incentive model (la) and the conditioning model of binge eating (Ib). 
The conditioned response to binge cues that should be measured according to the conditioned incentive theory is the presence or vividness of the image of binge food, and craving. In this thesis no enlarged craving is found during exposure to food in eating disordered subjects, compared to control subjects; both restrained and unrestrained (chapter 5) and bulimics and control women (chapter 6) reported increases in craving during exposure. Perhaps normal subjects were also able to imagine the hedonic effects of the food to which they were exposed. The relations between craving and food intake (chapter 4 and 6) and between craving and physiological responses (chapter 4 and 6) can be explained by the conditioned incentive model, as well as by the conditioning model of binge eating. However, the conditioning model of binge eating is the only model that can explain the relations between physiological responses and food intake (chapter 5 and 6). Research specific aimed at the conditioned incentive model could give additional and conclusive information. For example, exposure to cues not directly related to sensory aspects of food (mood, environmental cues, or stressful events) might induce differential effects in normal subjects and binge eaters. During this exposure, word recognition tasks or word stem completions might give insight in the activity or accessibility of mental representations of food. Afterwards, subjective ratings of craving and a taste test could reveal relations with craving and food intake.

In sum, improvements of studies on the conditioning model of binge eating can be made. More studies with subjects with regular clinical eating binges is warranted, as are measurements during exposure to natural binge cues, to exclude the possibility that exposure to binge food in a laboratory setting is too weak to elicit conditioned reactivity. Although different physiological measurements can be interesting, they are not necessary to draw conclusions on the existence of conditioned preparation for food. Furthermore, it is possible that not the physiological effect the eating binge is conditioned, but the hedonic, incentive experience of eating the food. Research aimed at this model is necessary to sort this out.

\section{Therapy based on the conditioning theory}

Although no convincing evidence for the conditioning theory of binge eating is found, experimental therapy based on the conditioning theory is already practiced. This shortterm therapy is based on six interventions: explaining the conditioned theory of binge eating, identification of binge cues, and four techniques to break up the linkage between the cues and the eating binge: flooding, the alternative eating binge, eating binge food without cues and gradual exposure (Meijboom, 1998). During flooding, the patient is exposed in vivo and at the place where the patient normally has eating binges, to as many cues as possible. The entire binge ritual is played out, except for that the patient is not allowed to eat the food. The goal is to increase craving as high as possible and to let this craving extinguish, both within as between sessions. The 
alternative eating binge serves as substitute for a real eating binge, when a patient can't resist the urge to binge. During an alternative binge, palatable food is eaten which is as different from the prior eating binge as possible. This way, the relation between binge cues and food intake is not confirmed while the patient is working so hard to break this relation. During the third technique, the patient eats small amounts of personal binge food in different situations and context than during eating binges. In the fourth technique, the patient is asked to practice exposure gradually as homework. The results so far are promising. several (small) studies report a decrease of eating binges between 66 and $100 \%$. Also, cognitions, mood, self-esteem and social functioning improved (Hansen \& de Haan, 1995; Jansen, van den Hout, de Loof, Zandbergen \& Griez, 1989; Jansen, 2001; Schmidt \& Marks, 1988).

From these studies it appeared that cue exposure therapy alone is sufficient to decrease bulimic symptoms. If the conditioning model of binge eating is not correct, why would the therapy work? Perhaps the alternative model, the conditioned incentive model is correct. In this case, exposure to binge cues without eating causes extinction of the anticipated positive aspects of food, and thereby extinction of craving for food. When the binge cues do not elicit craving, there will be no more eating binges. Another possibility is that the effective elements of the therapy had nothing to do with extinction whatsoever.

Another option is that before the therapy, binge eaters tried to control eating binges by suppressing thoughts of food and eating binges. Trying not to think of food costs numerous efforts and subtraction or additional mental load (for example caused by emotions or daily hassles) might have made the attempt not only ineffective, but also countereffective: one starts to think more of food than before and loses control. This paradoxical effect of thought suppression is described and investigated by Wegner (1994). During the cue exposure therapy, patients are exposed to food while cognitive avoidance is prevented. The ineffective strategy of the patients might be abolished by the therapy.

Additional research is needed to get more insight which elements of a therapy are effective and by which mechanisms. This is an important issue, because it can help constructing a more effective therapy.

\section{Future research goals}

In the first place, additional research at the conditioned theory of binge eating is required, especially because the therapy derived from the theory seems to work well. As described above, measurements of physiological reactivity and craving before and during a natural eating binge is proposed as an adequate way to test the theory. If practical difficulties cannot be overcome, experimenters should take care that binge cues are presented as natural as possible during the exposure.

The conditioned incentive model states that not the physiological effect of food is conditioned, but the hedonic effects. Exposure to binge cues would elicit a 
representation of the food, which causes craving for the specific food and results in a binge. To test this model, the presence or vividness of the mental representation of binge food should be measured during exposure to binge cues. Tasks like word recognition and word stem completion during exposure could give more insight. Because exposure to palatable food items would probably also evoke the representation of the hedonic and sensory aspects of the food in normal subjects, other cues than food items are preferable. One can think of emotions, context, or the like. Similar to the other research using the cue exjosure paradigm, it is important to use personal aclequate cues.

Besides research related to the conditioning model, other perspectives might be interesting. For example, it is suggested that thought suppression might be an ineffective way to try to stop binge eating. Trying not to think of food may have they ironic effect that one thinks more about food (Wegner, 1994). Research so far, did find more food related thoughts in restrained eaters during and right after suppression instructions (Johnston, Bulik \& Anstiss, 1999; Oliver \& Huon, 2001). However, although restrained eaters were effective in suppressing thoughts of food, there were negative consequences in terms of increases in anxiety and distress (Oliver \& Huon, 2001). Long-term effects of suppressing thoughts of food, effects of additional stress or emotions and effects on eating behaviour are not investigated yet. Also, investigations to see whether binge eaters indeed use thought suppressing strategies to try to control eating behaviour and that these strategies are counterproductive and add to binge eating instead of reducing it, is needed.

In conclusion, fundamental research at cognitive and learning processes in eating behaviour is needed, as well as research in the effective mechanisms of therapeutic interventions. At this stage, it remains a question what brings subjects to binge or not to binge. 


\section{Summary}

Many people enjoy the taste of palatable food. However, some people don't know when to stop. One of the seven deadly sins in the bible is gluttony, an inordinate desire to consume more than what one requires. Hence, excessive eating is as old as mankind and has a negative connotation ever since. This thesis deals with excessive eating, especially with binge eating. During an eating binge an abnormally large amount of food is eaten, within a short period of time. The amount of food is substantial larger than other people would eat under the same circumstances. Furthermore, the binge eater feels a lack of control over one's eating behaviour; one cannot prevent or stop the binge.

Eating binges play an important role in most eating disorders. Patients with bulimia nervosa, anorexia nervosa (binge eating/purging type) and the binge eating disorder regularly have binges (APA, 1994). Besides eating binges, these patients have higher general dissatisfaction (Rosenvinge, Borgen \& Börresen, 1999), lower selfesteem (Decaluwé \& Braet, 2001) and more negative self-schemas (Nauta, Hospers, Jansen \& Kok, 2000). In addition, subjects with eating binges often suffer fron negative moods and depression (Cooper \& Fairburn, 1986; Swift, Andrews \& Barklage, 1986). Finally, there are several health consequences associated with eating disorders (Jansen, 1998a). The question is why people still do have eating binges

A number of general risk factors are identified. Perfectionism, low confidlence, negative mood, child sexual abuse, stressful life-events and restrained eating behaviour can increase the risk of eating binges (Fairburn \& Cooper, 1989; Fairburn \& Gamer, 1988; Lacey, Coker \& Birtchnell, 1986; Loro \& Orleans, 1981; Mizes \& Christiano, 1995; Polivy \& Herman, 1993). Some models state that for each individual, different factors can have added to the disorder (Garfinkel \& Garner, 1982). However, no predictions or hypotheses can be derived from such a model, only descriptions.

Risk factors do not specify the reason why people have eating binges. Some important questions consider the triggering of an eating binge and the maintenance of binge eating. According to the boundary model of Herman and Polivy (1980), binge eating is closely related to efforts to restrain food intake. When subjects try to restrict their food intake, they have a self-imposed diet boundary, which determines how much they are allowed to eat. When this boundary is overstepped, the subject would have disinhibitive thoughts, like: "I"ve blown my diet, I might as well continue to cat". These disinhibitive thoughts would prompt excessive eating behaviour. Research indeed showed that restrained eaters ate more during a taste test after consuming a milkshake than without a preload. The unrestrained eaters however ate less when they already consumed a preload (Herman \& Mack, 1975). It appeared from several experiments, that not only eating a preload can induce disinhibitive eating behaviour in restrained eaters, but also the induction of emotions and distraction of attention has this effect (Boon, 1998). The prevailing explanation is that the diet boundary of the restrained eaters is overstepped (in case of consuming a preload) or became irrelevant or ineffective (in case of emotions or distraction). However, there is no direct support for the intervening role of disinhibitive cognitions or the existence of a diet boundary, Therefore, the exact mechanism how these triggers lead to binge eating is not clear yet. 
Another model on why people binge is the conditioning model of binge eating (Jansen, 1998b). When someone regularly has eating binges, and these binges are reliable preceded by specific cues (like emotions, being home alone, time of day or the sight and smell of food), these cues become predictors of a binge. For example, if someone is always depressed and alone during a binge, this can result in that depression and loneliness become predictors of an eating binge. According to the model, exposure to these cues will evoke conditioned responses, which prepare the body for the enormous amount of food that is expected. For example, the person starts to salivate; the stomach shows increased activation and the concentration of blood sugar decreases. These adjustments are supposed to be experienced as an irresistible craving for food and thus make a binge almost inevitable. The conditioning model is founded on three important assumptions: 1. Exposure to binge cues evokes physiological reactivity. 2. This reactivity is experienced as craving. 3. The reactivity and craving lead to an eating binge. In the literature, some evidence is found for these assumptions, although the outcomes are not consistent. The therapy based on this model, seems to be very effective (Jansen, 2001). In this therapy, patients are exposed to binge cues while eating is prevented. Hereby, the conditioned physiological reactivity and craving for food will extinguish. The conditioning model can play an important role in explaining the mechanisms underlying binge eating and provide new therapy methods for eating disorders. However, the empirical evidence is still scarce; in this thesis the assumptions of the conditioning model will be tested in a number of studies.

In the method part of this thesis, several techniques to measure the salivary response are examined. After all, the production of salivation is an important bodily response, related to appetite and the digestion of food. In the most frequently used method, dental rolls are kept inside the mouth and the increase in weight of the rolls is measured. An import disadvantage of this method for using it during food exposure, is that it is rather unpleasant to keep dental rolls in one's mouth. This might interference with appetite, which is exactly what one tries to induce during food exposure. An alternative method is counting the number of swallows, which correlates with the salivation production. Swallowing can be measured by electromyography of the muscles used during the act of swallowing. This method is non-invasive and does not disturb appetite. To examine the validity, sensitivity and reliability of this method, women were exposed to saliva provoking stimuli, like lemon juice (chapter 2). Meanwhile, the salivary response was measured both by the dental roll method and the swallow method. Results showed that both methods were able to distinguish between the stimuli. Also, the scores on both methods were related to each other. This indicates that counting swallows is a valid and sensitive method.

In chapter 3 these results were replicated. Men and women were exposed to saliva provoking stimuli while their salivary response was measured. This time, a third method was tested, in which the electrophysiological activity of the parotid gland was measured. Again, the dental roll method and the swallow method proved to be sensitive and the scores on these methods were related to each other. However, the parotid method did not appear to measure a salivary response, it could not distinguish between the different stimuli and the activity was not related to the other two methods. The choice between the roll method and the swallow method, depends on the 
experimental design and needs. If it is important not to influence appetite and a laboratory with apparatus is available, the swallow method is recommended. When the measurements are outside the laboratories or if it is important that the subject can move freely, the use of dental rolls is advantageous.

During the second part of this thesis, the conditioning model of binge eating is tested. First, the reactivity of nomal women to food cues and an imitation-eating binge was examined (chapter 4). It appeared that the normal women responded during the exposure to food cues and during and after the eating binge with several physiological adjustments. The cue reactivity matched the binge reactivity, in that the physiological variables changed in the same direction. This means that the oue reactivity might be interpreted as gearing up the body, in order to digest the upcoming food as well as possible. Furthermore, significant correlations between dietary restraint and blood pressure, between blood pressure and craving, and between craving and food intake were found. Although these relations are not causal in nature, they support the assumption that physiological changes are experienced as craving for food and that this craving causes increased food intake.

In the subsequent study, low and high restraint eaters were exposed to food cues or control cues and completed a taste test afterwards (chapter 5). It was hypothesised that the restrained eaters would show more physiological reactivity, report more craving and eat more, compared to the unrestrained eaters. However, it appeared that contrary to these expectations, restrained eaters showed smaller physiological reactivity (heart rate, salivation and gastric activity) to the food cues than the unrestrained eaters. Conversely, both groups reported more craving during food exposure and both groups also ate the same amount of food during the taste test. There was a significant correlation between gastric activity and food intake over all subjects. These results do support the conditioning model of eating in unrestrained eaters, they showed increased physiological responses and craving during exposure to food cues compared to the control cues, and physiological reactivity was related to food intake. The restrained eaters however, showed less cue reactivity, contrary to the expectations. Several explanations are suggested; first it is possible that the restrained eaters are successful dieters, have less experience with candy and therefore show less conditioned physiological reactivity. In this case, the restrained eating would be a poor model for binge eating. Second, it is possible that the restrained eaters controlled and suppressed their reactivity during the food exposure and the laste test by using cognitive strategies. Indeed, restraintness was correlated to a style of cognitive suppressing unwanted thoughts. However, this option should be tested experimentally and for the time being it must be concluded that the conditioning model of binge eating received no support.

In the final study (chapter 6), women with bulimia nervosa were exposed to their personal binge food and performed a taste test afterwards, in which caloric food intake was measured. Their responses were compared to normal women, who were exposed to their favourite food items. It was hypothesised that the bulimic women would show more physiological reactivity during the exposure, report more craving and eat more during the taste test. However, no differences between groups in physiological responding were found. Both groups showed an increase in heart rate, finger pulse amplitude and skin conductance. Overall, the bulimic women reported 
less craving and more depression, but no differential effect of the exposure was found. Also, no differences in caloric intake were found. The amount of food eaten during the taste test was positively related to craving and negatively to increases in finger pulse amplitude (fpa) during the exposure. Also, increases in fpa were negatively related to craving. Therefore, also in this study support is found for the conditioned model of normal eating, albeit not of binge eating. After all, both groups showed an increase in physiological reactivity and craving, these concepts were mutual related and what's more, both were related to the size of the food intake. An important conclusion of this experiment is however that exposure to individualised binge food did not induce an eating binge in the bulimic women, they kept control over their eating behaviour. Yet, there were three women who didn't want to perform the taste test, but were persuaded to do so for a shorter period. Surprisingly, these three women ate more during this shorter period than the other women did during a longer interval. The means of the scores of these three subjects revealed that they were more depressed, reported more craving and hunger and showed a smaller increase in finger pulse amplitude. It appeared therefore, that for these three bulimic women the conditioning model of binge eating is applicable. However, these conclusions are based on the means of three subjects, and not founded on statistical tests. The support for the conditioning model of binge eating is therefore not convincing.

In sum, the findings of the studies in this thesis do support the three assumptions of the conditioning mode] of normal eating: 1. Exposure to food cues evokes reactivity (chapter $2,3,4,5$ and 6 ); 2 . This reactivity was related to craving for food (chapter 5 and 6$) ; 3$. Both the cue reactivity and craving were related to food intake (chapter 4 and 6). However, the relation between conditioned reactivity and craving with binge eating has not been shown. Exposure to food cues did not elicit increased reactivity or craving in restrained eaters or bulimic women, and they didn't eat more. An important question is whether because of methodological or experimental shortcomings, the studies failed to show increased reactivity, or if binge eaters just don't thave increased cue reactivity. Therefore, possible shortcomings of the studies will be evaluated.

First, it is possible that the cues presented in a laboratory do not match the cues during a natural eating binge well enough. The subjects were in a laboratory room, attached to electrodes and apparatus and they must have felt observed. Perhaps these differences with the natural binge settings made the cues too weak to elicit conditioned responses. To test this hypothesis, measurements before and during a spontaneous eating binge in the natural environment should be made.

A second problem is that the conditioned reactivity cannot be interpreted as preparation for food. It is suggested that the reactivity is emotional in nature (Vögele \& Florin, 1997) or conditioned hedonic reactivity. In this case, the sensory, incentive feelings churing an eating binge are conditioned. When cues come to predict an eating binge, exposure to these cues elicits a mental hedonic representation of the food (Zellner \& Edwards, 2001). For example, the binge eater can almost taste the chocolate, feels it melt in her mouth and feels the sensation of the creamy substance against her tongue and palate, during exposure to binge predicting cues. According to the theory, this image or representation increases craving and can lead to actions to obtain the food and in the end to an eating binge. Physiological responses are a 
possible consequence of craving for food and not the originator. However, just like the original conditioning theory, binge cue exposure would elicit increased craving in binge eaters, which would lead to an eating binge. In this thesis therefore, the conditioned incentive model is not supported.

Finally, in this thesis only one study with subjects with clinical eating binges is performed. A practical reason is that it is difficult to find patients with a clinical diagnosis willing to participate in scientific research. However, the statistical power of research at cue reactivity will be improved when more research with binge eaters is performed.

In conclusion, in this thesis no support is found for the conditioning model of binge eating, only for normal eating. More research with participants with real eating binges is recommended, as well as measurements during a real eating binge. At this stage, to binge or not to binge remains the question. 


\section{Samenvatting}

Veel mensen houden van lekker eten. Echter, niet iedereen kan hierbij maat houden. Een van de zeven hoofdzonden die genoemd wordt in het oude testament, is onmatig eetgedrag; uit de hand gelopen eetgewoonten zijn zo oud als de mensheid en hebben sindsdien een negatieve connotatie. Dit proefschrift gaat over onmatig eetgedrag en in het bijzonder over 'eetbuien': een eetbui is een extreme vorm van onmatig eetgedrag. Tijdens een eetbui worden er grote hoeveelheden voedsel gegeten binnen korte tijd. De hoeveelheid die gegeten wordt is anzienlijk groter dan de hoeveelheid die andere mensen onder dezelfde omstandigheden zouden eten. Ook is er tijdens de eetbui sprake van controleverlies: de overeter heeft het gevoel niet te kunnen stoppen met eten en kan ook niet woorkomen dat er gegeten zou worden.

Eetbuien spelen een voorname rol bij de meeste eetstoomissen. Patiènten met boulimia nervosa, anorexia nervosa (het eetbui/purgerende type) en de eetbuistoonis hebben regelmatig last van eetbuien (APA, 1994). Deze patienten hebben niet alleen last van eetbuien, ze zijn in het algemeen minder tevreden (Rosenvinge et al., 1999), hebben minder zelfvertrouwen (Decaluwé \& Breat, 2001), zijn negatiever over zichzelf (Nauta et al., 2000) en hebben meer last van negatieve stemmingen (Cooper en Fairburn, 1986) dan mensen zonder eetproblemen. Daarbij zijn eetbuien slecht voor de gezondheid (Jansen, 1998a). De vraag is waarom mensen dan toch eetbuien hebben.

Een aantal algemene risicofactoren is geïdentificeerd. Het werd gevonden dat perfectionisme, weinig zelfvertrouwen, negatieve stemming, seksueel misbruik tijdens de jeugd, stressvolle gebeurtenissen in het algemeen en lijngedrag het risico van eetbuien kunnen vergroten (Fairburn \& Cooper, 1989; Fairburn \& Garner, 1988; Lacey, Coker \& Birtchnell, 1986; Loro \& Orleans, 1981; Mizes \& Christiano, 1995; Polivy \& Herman, 1993). Volgens sommige theorieën zijn de factoren die bijdragen aan een eetstoornis per individu verschillend (Garfinkel \& Garner, 1982). Echter, deze assumptie gaat ten koste van de voorspellingen die vanuit het model te maken zijn.

Risicofactoren zeggen nog niets over hoe het nu precies komt dai mensen eetbuien hebben. Enkele belangwekkende vragen die hier wel op ingaan zijn: hoe wordt een eetbui uitgelokt en hoe worden eetbuien in stand gehouden? Volgens het Boundary-model (Herman \& Polivy, 1980) speelt het houden van een dieet een cruciale rol. Mensen die aan de lijn doen zouden een zogenaamde dieetgrens in hun hoofd hebben, en deze dieetgrens bepaalt hoeveel ze van zichzelf mogen eten. Als de grens wordt overschreden, gooien ontremmende gedachten (zoals "nu is mijn dieet toch verpest, ik kan nu net zo goed door blijven eten") roet in het eten. Het zouden deze of vergelijkbare ontremmende gedachten zijn die vervolgens tot overmatige voedselinname aanzetten. Onderzoek toonde inderdaad aan dat lijners na het nuttigen van een milkshake meer ijs aten tijdens een zogenaamde smaaktest dan wanneer ze geen milkshake gegeten hadden. Niet-lijners aten daarentegen juist minder als ze van tevoren een milkshake gegeten hadden (Herman \& Mack, 1975). Uit de vele varianten op dit onderzoek bleek dat niet alleen het vooraf iets eten, maar ook het opwekken van emoties en het afleiden van de aandacht, leidt tot een grotere voedselinname van lijners dan van niet-lijners tijdens een zogenaamde smaaktest (Boon, 1998). De gangbare verklaring is dat de dieetgrens van de lijners door deze manipulaties 
overschreden is (in geval van geforceerd een voorafje eten) of van ondergeschikt belang werd (in geval emoties en afleiding). Echter, zowel het bestaan van de dieetgrens, als de aanwezigheid en causale rol van ontremmende gedachten is miet aangetoond. Hoe het komt dat emoties, afleiding en vooraf iets eten leidt tot overmatige consumptie is nog niet duidelijk.

Een ander model dat probeert te verklaren waarom mensen een eetbui hebben, is het conditioneringmodel van eetbuien (Jansen, 1998b). Als mensen zich regelmatig overeten volgens een vast patroon, kan dit patroon of ritueel een goede voorspeller van een eetbui worden. Bijvoorbeeld, als iemand altijd somber en alleen is tijdens een eetbui, kan dit ertoe leiden dat somberheid en eenzalambeid voorspellers van de eetbui worden. Ook de aanblik en geur van lekker eten blijkt vaak een voorspeller van een eetbui te zijn. Blootstelling aan deze stimuli wekt volgens het model aangeleerde lichamelijke reactiviteit op. Deze reacties zorgen ervoor dat het lichaam zich voor kan bereiden op de grote hoeveelheid voedsel die gaat komen. De volgende keer als de persoon alleen en somber thuis is, treft het lichaam vast haar maatregelen. Het heeft immers als het ware geleerd dat er weer een eetbui komt en dat is een goede reden om zich lichamelijk vast voor te bereiden op de voorspelde inname. Er vindt bijvoorbeeld een toename van speeksel plaats (het water loopt in de mond), maagcontracties nemen toe (de maag begint te knorren) en de concentratie bloedsuiker daalt. Deze lichamelijke veranderingen worden volgens het model ervaren als een onweerstaanbare trek in eten en een eetbui is hierdoor haast onvermijdelijk. Als er daadwerkelijk een eetbui plaatsvindt, is dit tevens een bevestiging van de voorspellende waarde van de stimuli. Dit conditioneringmodel van eetbuien berust op drie belangrijke assumpties: 1) Blootstelling aan stimuli die een eetbui voorspellen wekt lichamelijke reacties op, 2) Deze lichamelijke reacties worden ervaren als een onweerstaanbare trek in eten, en 3) De lichamelijke reacties en de drang naar eten leiden samen tot een eetbui.

In de literatuur is enige ondersteuning voor deze assumpties gevonden, hoewel de bevindingen niet uniform zijn. De therapie die op deze theorie gebaseerd is, lijkt op het eerste gezicht effectief (Jansen, 2001). In deze therapie worden patiënten die regelmatig eetbuien hebben, langdurig blootgesteld aan de stimuli die de eetbuien voorspellen, terwijl er niet gegeten mag worden (respons preventie). De lichamelijke reacties en de drang naar eten doven daardoor uit (Meijboom, 1998). Het conditioneringmodlel verklaart waarom eetbuien blijven voortbestaan en speelt potentieel een belangrijke rol bij de ontwikkeling van een nieuwe en effectieve therapie. De empirische evidentie voor het model is evenwel nog gering; in deze dissertatie zijn de assumpties van het conditioneringmodel in een serie experimenten getest.

In het methode deel van dit proefschrift wordt een aantal technieken om specksel te meten onderzocht. Immers, speekselproductie is een belangrijke lichamelijke reactie, die met honger, trek en de spijsvertering samenhangt. De meest gangbare manier, waarbij tandwatten in de mond gehouden worden en de gewichtstoename van de watjes gemeten wordt, heeft als nadeel dat het vies gevonden wordt. Daardoor zou het de eetlust kunnen verstoren en het was juist de bedoeling drang om te eten op te wekken. Een alternatieve methode is het tellen van het aantal keren dat iemand slikt, hetgeen zou correleren met speekseltoename. Het aantal keren 
dat geslikt wordt, wordt met behulp van een electromyogram van de slikspieren gemeten. Hierbij wordt de eetlust niet verstoord en de methode is daarom ean interessant alternatief. Om de betrouwbaarheid en validiteit van de methode te bepalen, werden vrouwen blootgesteld aan stimuli die speeksel opwekten, zoals citroensap en de geur van warme lasagne (hoofdstuk 2). Ondertussen werd de speekseltoename gemeten met de watjesmethode en met de slikmethode. Het bleek dat beide methoden de stimuli konden onderscheiden van elkaar. Bovendien waren de scores van beide methoden aan elkaar gerelateerd. Dit geeft aan dat het tellen van het aantal keren dat geslikt werd een valide en betrouwbare methode is. In hoofdstuk 3 werden mannen en vrouwen wederom blootgesteld aan stimuli die speeksel opwekken. Ditmaal werd er naast de wattenmethode en het tellen van slikken nog een derde methode getest: het meten van elektrofysiologische activiteit van de parotid speekselklier. Uit de resultaten bleek nogmaals dat de eerste twee methoden sensitief en betrouwbaar waren. Echter, de derde methode bleek niet in staat onderscheid te maken tussen de verschillende stimuli en was ook niet gerelateerd aan de eerste wee methoden. De conclusie luidde daarom dat de parotid methode niet bruikbaar is en de andere twee methoden wel.. Het design en de vraagstelling van het onderzoek bepalen vervolgens welke methode te prefereren is. Als er geen aversie of walging mag worden opgewekt, en er is een laboratorium met elektrofysiologische apparatuur aanwezig, wordt het tellen van het aantal keren slikken aangeraden. Als er echter metingen buiten een laboratorium plaatsvinden of als het belangrijk is dat de proefpersoon zich vrijelijk kan bewegen, dan biedt de speekselmeting met behulp van watten voordeten.

In het tweede deel van deze dissertatie wordt het conditioneringmodel van eetbuien getest. In de eerste studie van dit deel (hoofdstuk 4) werden de lichamelijk en subjectieve responsen van normale vrouwen onderzocht, zowel tijdens blootstelling aan de geur en het zien van lekker eten, als tijdens een eetbui waarbij de opdracht was zoveel mogelijk te eten. De vrouwen reageerden met een heel scala aan lichamelijke reacties op zowel de blootstelling aan eten als op de 'eetbui', De reacties kwamen grotendeels overeen; de fysiologische variabelen veranderden tijdens de blootstelling. en tijdens de eetbui in dezelfde richting. Dit betekent dat de reacties op de aamblik en geur van eten geinterpreteerd kunnen worden als het voorbereiden van het lichaam op de komst van eten, met als doel het eten zo goed mogelijk te verwerken en te verteren. Verder werden er significante correlaties gevonden tussen lijngedrag en bloeddruk, bloeddruk en drang om te eten en tussen drang om te eten en de daadwerkelijk gegeten hoeveetheid. Hoewel deze relaties niet causaal zijn, ondersteunen ze de assumptie dar lichamelijke veranderingen ervaren worden als drang om te eten en dat deze drang leidt tot een verhoogde voedselinname.

In de volgende studie (hoofdstuk 5) werden mensen uitgenodigd die hoog of laag scoorden op een vragenlijst die meet in welke mate mensen aan de lijn doen. Mensen met hoge scores doen veel aan de lijn en worden "lijners" genoemd, mensen met lage scores doen niet aan de lijn en worden 'niet-lijners' genoemd. Zowel de lijners als de niet-lijners moesten eerst intens ruiken aan lekker eten of aan controlestimuli (badparels) en daarna namen ze deel aan een smaaktest. Tijdens de blootstelling werden lichamelike reacties en drang gemeten en na afloop van de smaaktest werd er gemeten hoeveel er gegeten was. De verwachting was dat de lijners lichamelijke sterker zouden reageren tijdens de blootstelling aan het smakelijke 
voedsel, dat ze meer drang zouden voelen en dat ze vervolgens tijdens de smaaktest meer zouden eten, in vergelijking met de niet-lijners. Dit bleek niet het geval. De lijners vertoonden juist minder lichamelike reactiviteit (hartslag, maagactiviteit, specksel) tijdens het ruiken en zien van het smakelijke voedsel dan de niet-lijners. Daarentegen rapporteerden beide groepen meer drang om te eten tijdens blootstelling aan het smakelijke voedsel dan tijdens blootstelling aan de badparels en ook aten beide groepen evenveel tijdens de smaaktest. Er was een significante samenhang tussen maagactiviteit en het antal geconsumeerde calorieen: hoe actiever de maag tijdens de blootstelling, hoe meer er tijdens de daaropvolgende smaaktest gegeten werd. Deze resultaten steunen de conditioneringtheorie als het gaat om het eetgedrag van nietlijners: niet-lijners reageerden lichamelijk sterker tijdens de blootstelling aan het voedsel en ze rapporteerden meer drang om te eten. Belangwekkend is dat de lichamelijke woorbereiding op het eten gerelateerd was aan de hoeveelheid die gegeten werd. Echter, de lijwers vertoonden juist veel minder reactiviteit, een bevinding die tegen de theorie in druist. Hoe kan dit verklaard worden? Het is mogelijk dat de lijners die meededen aan het onderzoek succesvolle lijners waren. Succesvolle lijners hebben geen eetbuien; zij zullen daarom minder sterk geconditioneerd zijn en minder reactiviteit vertonen. Als dit zo is, dan zijn de geselecteende lijners geen goed model voor mensen met eetbuien. Een andere mogelijkheid is dat de lijners hun reacties onderdrukt hebben, met als doel controle te houden over hun eetgedrag. Het bleek dat de score op de lijnvragenlijst inderdaad gerelateerd was aan de score op een vragenlijst die de algemene tendentie meet om vervelende gedachten te onderdrukken. Echter, deze verklaring zou eerst experimenteel onderzocht moeten worden. Vooralsnog luidt de conclusie dat er geen aanwijzingen zijn dat eetbuien beinvloed worden door geconditioneerde lichamelijke reacties.

In het laatste onderzoek (hoofdstuk 6) werden patiënten met bulimia nervosa blootgesteld aan het voedsel dat ze gewoonlijk tijdens een eetbui opaten. Ze werden vergeleken met vrouwen zonder eetproblemen, die moesten kijken en ruiken aan hun favoriete eten of snoep. Na de blootstelling deden beide groepen een smaaktest, waurna er gemeten werd hoeveel de vrouwen aten. De hypothesen luidden dat de bulimische vrouwen meer lichamelijke reactiviteit zouden vertonen tijdens de blootstelling, meer drang zouden rapporteren en meer zouden eten tijdens de smaaktest. Echter, er werden geen verschillen in lichamelijke reacties gevonden; beide groepen vertoonden een toename in hartslag, doorbloeding van de vinger en huidgeleiding tijdens de blootstelling aan eten. Beide groepen rapporteerden een toename in de drang om te eten en beide groepen aten gemiddeld evenveel tijdens de smakktest. De hoeveelheid die gegeten werd, bleek gerelateerd aan de drang die gerapporteerd werd en an een kleinete toename van de doorbloeding van de vinger tijdens de blootstelling. Daamaast waren doorbloeding van de vinger en drang onderling aan elkaar gerelateerd. Ook in dit onderzoek blijkt dat het conditioneringsmodel voor nomal eren wel ondersteund word, maar voor eetbuien niet. Immers, beide groepen toonden een toename in lichamelijke reactiviteit en drang, deze concepten waren onderling gerelateend en bovendien waren beiden gerelateerd aan de grootte van de voedselinname. De belangrijkste bevinding is echter dat de blootstelling an eten geen verhoogde fysiologische reacties opwekte bij de meeste bulimische vrouwen en dat deze vrouwen hun controle over hun eetgedrag behielden 
tijdens de smaaktest. Wel waren er drie vrouwen die niet mee wilden doen an de smaaktest. Ze werden overgehaald om toch mee te doen, waarbij de duur van de test verkort werd van 10 naar 5 minuten. Opvallend was dat de drie vrouwen in deze kortere periode meer aten dan de overige vrouwen gedurende de langere periode. De gemiddelden van deze drie vrouwen toonden aan dat ze somberder waren, meer drang en honger rapporteerden en een kleinere toename vertoonden in de doorbloeding van de vinger. Voor deze drie vrouwen lijkt het conditioneringsmodel vool: eetbuien daarom op te gaan. Deze conclusies zijn echter gebaseerd op de gemiddelden van de drie vrouwen, zonder statistische toetsing. De juistheid van het conditioneringsmodel voor eetbuien kon ook in dit experiment niet overtuigend worden aangetoond.

Samenvattend kan gesteld worden dat voor de drie assumpties van het conditioneringsmodel van normaal eetgedrag steun is gevonden: 1) Blootstelling aan eten wekt lichamelijke reactiviteit op (hoofdstukken $2,3,4,5$ en 6), 2) Deze lichamelijke reactiviteit is gerelateerd aan drang om te eten (hoofdstuk 5 en 6) en 3) Lichamelijke reactiviteit en drang zijn gerelateerd aan voedselinname (hoofdstuk $4 \mathrm{en}$ 6). Echter, er is niet aangetoond dat geconditioneerde reactiviteit of drang gerelateerd is aan eetbuien. De blootstelling aan eten was niet voldoende om verhoogde reactiviteit en drang op te wekken in lijners of bulimische vrouwen. Dat deze vrouwen vervolgens niet meer aten, kan daar het logische gevolg van zijn. Een belangrijke vraag is nu of methodologische en experimentele tekortkomingen debet zijn aan het ontbreken van verhoogde reactiviteit, of dat mensen met eetbuien werkelijk geen verhoogde reactiviteit hebben. Daarom is het nuttig de problemen van het hier gepresenteerde onderzoek te evalueren.

Een eerste probleem zou kunnen zijn dat de voedselstimuli, gepresenteerd in een laboratorium terwijl verschillende fysiologische metingen gedaan werden, mogelijkerwijs niet genoeg lijken op de stimuli die aan een werkelijke eetbui vooraf gaan. De stimuli die in het laboratorium gepresenteerd zijn, zouden daarom niet sterk genoeg zijn om geconditioneerde reacties op te wekken. Om deze hypothese te toetsen, zouden lichamelijke en subjectieve reacties ambulant gemeten moeten worden; voorafgaand aan een echte eetbui, in de natuurlijke omgeving.

Een tweede probleem is dat de reactiviteit die tijdens de blootsteling aan het voedsel geregistreerd werd, misschien niet geïnterpreteerd kan worden als een voorbereiding op voedselinname. De reacties zouden bijvoorbeeld emotionele reactiviteit of geconditioneerde hedonische reactiviteit kunnen reflecteren in plaats van een lichamelijke preparatie op inname. In het geval van geconditioneerde hedonische reactiviteit zou het positieve sensorische gevoel dat tijdens een eetbui bestaat, geconditioneerd zijn. Blootstelling aan stimuli die een ectbui voorspellen zou een representatie van dit gevoel opwekken. De persoon kan als het ware de chips al voelen kraken tussen de tanden en proeft de zoute smaak. Deze representaties zouden vervolgens drang om te eten opwekken. Lichamelijke reacties zouden een bijwerking van de drang zijn, in plaats van de aanstichter. Echter, net zoals in het bestudeerde conditioneringsmodel zou blootstelling aan de juiste stimuli verhoogde drang opwekken in mensen met eetbuien en vervolgens leiden tot een verhoogde voedsel inname. In dit proefschrift wordt daarom ook geen ondersteuning voor dit geconditioneerde hedonische reactiviteitsmodel gevonden. 
Samenvating

Tot slot is er in deze dissertatie feitelijk slechts eén studie gedaan waarin mensen met klinische eetbuien participeerden (hoofdstuk 6). Dit onderzoek was gekoppeld aan cen behandelsudie, waardoor de instroom in het onderzoek relatief tratg verliep.

Beshuitend kan gesteld worden dat de theorie nog een laatste kans verdient door hichamelijke reactiviteit ambulant bij klinische groepen te meten, voorafgaande aan een echte, natuurlijke eetbui. Maar vooralsnog steunen de studies in deze dissertatie het conditoneringsmodel voor eetbuien niet, terwijl het model wel voor normaal eetgedrag lijkt op te gaan. To binge or not to binge, dat blifft de vraag. 


\section{References}

American Psychiatric Association (1994). Dhagnostic and statistical mannal of mental disoders, the edition. Washington, DC: American Psychiatric Association.

Andersen, H. B., Jensen, E. W., Madsbad, S., Nielsen, S. L., Burcharth, F., \& Christensen, N. J. (1992). Sham-feeding decreases cardiac output in nomall subjects. Clinical Physiology, 12, 439-42.

Beebe, D.W., Holmebeck, G.N., Albright, J.S., Noga, K. \& Decastro, B. (1995). Identification of "binge-prone" women: an experimentally and psychometrically" validated cluster analysis in a college population. Addictive Behowions, 20.451462.

Berntson, G.G., et al. (1997). Heart Rate Variability: Origins, methods, and interpretive caveats. Psychophysiology, 34, 623-648.

Boon, B.J.F. (1998). Why dieters overeat: on the cognitive regulation of eating behavior (pp. 11-43). Amsterdam: Thesis Publishers.

Boon, B., Stroebe, W., Schut, H. \& Jansen, A. (1997). Does cognitive distraction lead to overeating in restrained eaters? Behavioural and Cognitive Psychotherapy. $25,319-327$.

Boon, B., Stroebe, W., Schut, H. \& Jansen, A. (1998). Food for thought: Cognitive regultaion of food intake. British Jornal of Health Psychology, 3, 27-40.

Bradley, M.M. (2000). Emotion and motivation. In: J.T. Cacioppo, L. G. Tassinary \& G.G. Bernston (Eds.). Handbook of Psychophysiology. 2nd ed. (pp 602-642). New York: Cambridge University Press.

Broberg, D.J. \& Bernstein, I.L. (1989). Preabsorptive insulin release in bulimic women and chronic dieters. Appetite, 13, 161-169.

Bruce, B. \& Agras, W.S. (1992) Binge eating in fentales: A population-based. investigation. Iniernational Journal of eating Disorders, 12,365-373.

Bulik, C.M. Lawson, R.H. \& Carter, F.A. (1996). Salivary reactivity in Restrained and Unrestrained Eaters and Women with Bulimia Nervosa. Appetile, 27. 15-24.

Bulik, C.M., Sullivan, P.F., Joyce, P.R., Carter, F.A.\& Mclntosh, V. V. (1998). Predictors of 1-year treatment outcome in bulimia nervosa. Comprehensive Psychiatry, 39, 206-214.

Carter, F. A., Bulik, C.M., Mclntosh, V.V. \& Joyce, P.R. (2001). Changes in cue reactivity following treatment for bulimia nervosa. International Journal of Eaing Disorders, 29.336-344.

Carter, B.L. \& Tiffany, S.T. (1999). Meta-analysis of cue-reactivity in addiction research. Addiction, 94, 327-340.

Childress, A.R., Ehrman, R., Rohsenow, D.J., Robbins, S.J. \& O'Brien, C.P., (1992). Classically conditioned factors in drug dependence. In: J.H. Lowinson, P. Ruiz, R.B. Millman \& J.G. Langrod (Eds.). Substance abuse: a comprehersive textbook, 2nd Ed. (pp 56-69). Baltimore etc: Williams \& Wilkins.

Cools, J., Schotte, D.E. \& McNally, R.J. (1992). Emotional arousal and overeating in restrained eaters. Jourmal af Abnomal Psychology, 2, 348-351. 
Cooney, N.L., Baker, L.H. Pomerleau, O.F., \& Josephy, B. (1984). Salivation to Drinking Cues in Alcohol Abusers: Toward the Validation of a Physiological Measure of Craving. Addictive Behaviors, 9, $91-94$.

Cooney, N.L. Litt, M.D. Morse, P.A. Bauer, L.O., \& Gaupp, L. (1997). Alcohol Cue Reactivity, Negative-Mood Reactivity, and Relapse in Treated Alcoholic Men. Joumal of Abnormal Psychology, 106, 243-250.

Cooper, P.J. \& Bowskill, R. (1986). Dysphoric mood and overeating. British Joumal of Clinical Psychology, 25, 155-156.

Cooper, P.J. \& Fairbum, C.G. (1986). The depressive symptoms of bulimia nervosa. British Journal of Psychiatry, 148, 268-274

Crowther, J.H., Sanftner, J., Bonifazi, D.Z. \& Shepherd, K.L. (2001). The role of daily hassles in binge eating. Intemational Joumal of Eating Disorders, 29, 449-454.

Dauncy, M.J., Haseler, C., Thomas, D.P. \& Parr, G. (1983). Influence of a meal on skin temperatures estimated from quantitative IR-thermography. Experientia. $39.860-862$.

Davis, C., Hing, M., \& Co, M. (1990). A new measure of the human salivary response. Canadian Psychology, 31, 302 (abstract).

Davis, C., Bauslaugh, T., Wintrup, A., (1996). Noninvasive recording of human salivary activity from surface electrodes: logic, method, and application. Psychophysiology, 33, S7.

Davis, R., Freeman, R.J. \& Garner, D.M. (1988). A naturalistic investigation of eating behavior in Bulimia Nervosa. Joumal of Consulting and Clinical Psychology, $56,273-279$.

Dawson, M. E., \& Reardon, P. (1969). Effects of facilitory and inhibitory sets on GSR conditioning and extinction. Journal of Experimental Psychology, 82, 462-466.

Decaluwé, V. \& Braet, C. (2001). Prevalentie en psychologische aspecten van eetbuien. bij obese jongeren. Gedrag \& Gezondheid, 29, 86-97.

de Mey, C., Hansen Schmidt, S., Enterling, D. \& Meineke, I. (1989). Time course and nature of postprandial haemodynamic changes in normal man. Clinical Physiology, 9.77-87.

Drummond, P.D. (1995). Effect of imagining and actually tasting a sour taste on one side of the tongue. Physiology and Behavior, 57.373-376.

Drummond, D.C., Tiffany, S.T., Glantier, S., \& Remington, B. (Eds.).(1995). Addictive behavioum. Cue exposwe Theory and Practice. Chichester: John Wiley \& Sons.

Epstein, L.H., Rodefer, J.S., Wisniewski, L., \& Caggiula, A.R. (1992). Habituation and dishabituation of human salivary response. Physiology and Behavior. 51 , $945-950$.

Epstein, L.H., Wisniewski,L., deFlavia, P., \& Mitchell, S. (1995). Salivary responding and the duration of measurement. Behavior Research Methods, Instruments and Computers, 27, 379-382.

Epstein, L.H., Paluch, R., \& Coleman. (1996). Differences in salivation to repeated food cues in obese and nonobese women. Psychosomatic Medicine, 58, 160 164.

Epstein, L.H., Paluch, R., Smith, J.D. \& Sayette, M. (1997). Allocation of attentional resources during habituation to food cues. Psychophysiology, 34, 59-64 
Fairbum, C.G., \& Beglin, S.J. (1994). The assessment of eating disorders: Tnterview or self-report questionnaire? International Joumal of Eating Disorders. 16, 363370 .

Fairburn, C.G. \& Cooper, P.J. (1989). Eating disorders. In: Hawton, Keith Hawton \& Paul M. Salkovskis, Joan Kirk \& David M. Clark (Eds), Cognitive behaviow" therapy for psychiatric problems: A practical guide. (pp 277-314). New York: Oxford University Press.

Fairbum, C.G. \& Garner, D.M. (1988). Diagnostic criteria for anorexia nervosa and bulimia nervosa: The importance of attitudes to shape and weight. In: David M. Gamer \& Paul E. Garfinkel (Eds.), Diagnostic issues in anorexia nervosa and bulimia nervosa. Brumer/Mazel eating disorders monograph series. No. 2. (pp. 36-55). Philadelphia: Brumner/Mazel, Inc.

Fairbum, C.G., Welch, S.L., Doll, H.A., Davies B.A. \& O'Comnor, M.E. (1997). Risk factors for bulimia nervosa: A community-based case-control study. Archives of General PSychiatry, 54, 509-517

Fedoroff, I. C., Polivy, J., \& Herman, C. P. (1997). The effect of pre exposure to food cues on the eating behavior of restrained and unrestrained eaters. Appetie, 28 , 33-47.

Field, A.E., Camargo, C.A., Barr Taylor, C., Berkey, C.S., Frazier, A.L., Gillman, M.W. \& Colditz, G.A. (1999). Overweight, weight concerns and bulinic behaviors among girls and boys. Jommat of American Academic Child and Adolescent Psychiatry, 38, 754-760.

First, M.B., Spitzer, R.L., Gibbon, M. \& Willians, J.B.W. (1995). Structwed Clinical Interview for DSM-IV Axia I Disonders. New York. New York State Psychiatric Institute.

Franchina, J.J., \& Slank, K.L. (1988). Effects of deprivation on salivary flow in the apparent absence of food stimuli. Appetite, 10, 143-147.

Garfinkel, P.E. \& Garner, D.M. (1982). The multidimensional nature of Anorexia Nervosa. In: P.E. Garfinkel \& D.M. Garner (Eds.), Anorexia Nervosa: A multidimensional perspective (pp. 188-213). New York: Brunner/Mazel.

Glautier, S. \& Remington, B. (1995). The form of responses to drug cues. In: D.C. Drummond, S.T. Tiffany, S. Glautier \& B. Remington (Eds), Addictive behaviour, cue exposure, theory and practice, (pp. 21-46.). Chichester: Jolm Wiley \& Sons.

Gorman, B.S. and Allison, D.B. (1995). Measures of restrained eating, In: Allison, D.B. (ed), Handbook of Assessment methods for eating behavioss and wetghtrelated problems. Sage Publications, California.

Gormezano, I. (1966). Classical Conditioning. In J.B. Sidowski (Ed.), Experimental Methods and Instrumentation in Psychology (pp. 383-421). New York:

McGraw-Hill Book Company.

Greenberg, B.R. (1986). Predictors of binge eating in bulimic and nonbulimic women. International Journal of eating Disorders, 5, 269-284.

Guertin, T.L. (1999). Eating behavior of bulimics. self-identified binge eaters, and non-eating-disordered individuals: what differentiates these populations? Clinical Psychology Review, 19,1-23. 
Hansem, A. \& de Haan, E. (1995). De behandeling van bulimia nervosa met cueexposure; ervaringen uit de praktijk, Directieve Therapie, 15, 279-291.

Harvey, C. B., \& Wickens, D. D. (1973). Effects of cognitive control processes on the classically conditioned galvanic skin response: $\mathrm{A}$ within-subjects design. Journal of Experimental Psychology, 101, 278-282.

Featherton, T.F. \& Baumeister, R.F. (1991). Binge eating as escape from selfawareness. Psychological Bulletim, 110, 86-108.

Heatherton, T.F. Herman, C.P., Poliwy, I., King, G.A. and McGree, S.T. (1988). The (mis)measurement of restraint: An analysis of conceptual and psychometric issues. Journal of Abnormal Psychology, 97, 19-28.

Heatherton, T.F., Nichols, P., Mahamedi, F. \& Keels, P. (1995). Body weight, dieting, and eating disorder symptoms among college students, 1982 to 1992 . American Journal of Psychiatry, 152, 1623-1629.

Herman, C.P., \& Mack, D. (1975). Restrained and unrestrained eating. Joumal of Personality, 43, 647-660.

Herman, C.P., \& Polivy, J. (1980). Restrained eating. In A.B. Stunkard (Ed.), Obesity (pp. 208-255). Philadelphia: Saunders.

Herman, C.P. \& Polivy, J. (1984). A boundary model for the regulation of eating. In: A.J. Stunkard \& E. Stellar (Eds.), Eating and its disorders, (pp. 141-156). New York: Raven Press.

Hirai, A., Tanabe, M. \& Shido, O. (1991). Enhancement of finger blood flow response of postprandial human subjects to the increase in body temperature during exercise. European Journal of Applied Physiology, 62, 221-227.

Hodgson, R.J., \& Greene, J.B. (1980). The saliva priming effect, eating speed and the measurement of hunger. Behaviour Research and Therapy, 18, 243-247.

Hoek, H. W. (1995). The distribution of eating disorders. In: K.D. Brownell \& C.G. Fairburn (Eds.), Eating Disoredrs and Obesity: a Comprehensive Handbook (pp. 207-211). New York: Guilford Press.

Jansen, A. (1994). The learned nature of binge eating. In C. R Legg, \& D.A. Booth (Eds.), Appetite (Vol. 8, pp. 193-211). Oxford: Oxford University Press.

Jansen, A. (1998a). Eating Disorders. In: A.S. Bellack \& M. Hersen (Eds). Comprehensive Chinical Psychology (pp. 649-667). Oxford: Elsevier Limited, Pergamon Press.

Jansen, A. (1998b). A learning model of binge eating: Cue reactivity and cue exposure. Behaviour Research and Therapy, 36, 257-272.

lansen, A. (2001). Towards effective treatment of eating disorders: nothing is as practical as a good theory. Behaviour Research and Therapy, 39, 1007-1022.

Jansen, A., Broekmate, J. \& Heymans, M. (1992). Cue exposure vs sel-control in the treatment of binge eating: A pilot study. Behaviour Reseanch and Therapy, 27, $247-252$

Jansen, A., Merckelbach, H., Oosterlaan, J., Tuiten, A. \& van den Hout, M.A. (1988). Cognitions and self-talk during food intake of restrained and unrestrained eaters. Behavion Reseanch and Therapy, 26, 393-398.

Jansen, A., \& van den Hout, M.A. (1991). On being led into temptation:

"Counterregulation" of dieters after smelling a "preload". Addictive Behaviors, 16, $247-253$. 
Jansen, A., van den Hout, M.A., de Loof, C., Zandbergen, I. \& Griez, E. (1989). A case of Bulimia successfully treated by cue exposure. Jownal of Behaviour Therapy and Experimental Psychiatry, 20, 327-332.

Jansen, A., van den Hout, M. \& Griez, E. (1990). Clinical and non-chinical binges. Behaviour Research and Therapy, 28,439-444.

Johnson, W.G., Jarell, M.P., Chupurdia, K.M. \& Willamson, D.A. (1994). Repeated binge/purge cycles in bulimia nervosa: role of glucose and insulin.

International Journal of Eating Disorders, 15, 331-341.

Johnston, L., Bulik, C.M. \& Anstiss, V. (1999). Suppressing thoughts about chocolate. International Journal of Eating Disorders, 26, 21-27.

Kaneko, H., Sakakibara, M., Mitsuma, T., \& Monise K. (1995). Possibility of postprandial electrogastrography for evaluating vagal/nonvagal cholinergic activity in humans, through simultaneous analysis of postprandial heart rate variability and serum immunoreactive hormone levels. American Joumal of Gastroenterology, 90,603-9.

Kapila, Y.V., Dodds, W.J., Helm, J.F., \& Hogan, W.J. (1984). Relationship Between Swallow Rate and Salivary Flow. Digestive Diseases and Science, 29, 528-533. Kaplan, R.F., Cooney., N.L., Baker, L.H., Gillespie, R.A., Meyer, R.E., \& Pomerleau, O.F.S.O. (1985). Reactivity to alcohol-related cues: physiological and subjective responses in alcoholics and nonproblem drinkers. Journal of Stud. Alcohol, 46, 267-272.

Karhunen, L. J., Lappalainen, R.I., Tammela, L., Turpeinen, A.K. \& Uusitupa, M.I.J.A.D. (1997). Subjective and physiological cephalic phase responses to food in obese binge eating women. International Jound of eating Disorders, $21,321-328$.

Klajner, F., Herman, C.P., Polivy, J., \& Chhabra, R. (1981). Human Obesity, Dieting, and Anticipatory Salivation to Food. Physiology and Behavior, 27, 195-198

Kinzl, J.F., Traweger, C., Trefalt, E., Mangweth, B. \& Biebl, W. (1999). Binge eating disorder in females: A population-based investigation. International Journal of Earing Disonders, 25, 287-292.

Laberg, J.C. (1990) What is presented, and what prevented, in cue exposure and response prevention with alcohol dependent subjects? Addictive Behowiors, 15 . $367-386$

Lacey, J.H., Coker, S. \& Birtchnell, S.A. (1986). Bulimia: Factors associated with its etiology and maintenance. International Joumal of Eating Disorders, 5, 475 487 .

LeGoff, D.B., Leichner, P., \& Spigelman, M.N. (1988). Salivary response to olfactory food stimuli in anorexics and bulimics. Apperite, $1 /, 15-25$.

Lipsitz, L.A., Ryan, S.M., Parker, J.A., Freeman, R., Wei, J.Y. \& Goldberger, A. L. (1993). Hemodynamic and autonomic nervous system responses to mixed meal ingestion in healthy young and old subjects and dysautonomio patients with postprandial hypotension. Circulation, 87, $391-400$.

Loro A.D. \& Orleans, C.S. (1981). Binge eating in obesity: Preliminary findings and guidelines for behavioral analysis and treatment. Addictive Behaviors, $6.155-$ 166. 
Mattes, R. D. (1997). Physiological Responses to Sensory Stimulation by Food: Nutritional Implications. Joumal of the American Dietetic Association, 97, 406410.

McFarlane, T., Poliwy, J. \& Herman, C.P. (1998). Effects of false weight feedback on mood, self-evaluation and food intake in restrained and unrestrained eaters. Jowmal of Abnomal Psychology, 107, 312-318.

Mauler, B., Tuschen, B., \& Hamm, A. (1997). Fear or craving: startle reflex. modulation during viewing of food cues in deprived and nondeprived bulimics. Psychophysiology, 34, S1, 562.

Meijboom, A. (1998). Cue exposure. In: A. Jansen \& A. Meijboom (Eds) Behandelingsstrategieen bij bulimia nervosa. Houten: Bohn Stafleu van Loghum.

Meyer, C., Waller, G. \& Waters, A. (1998). Emotional states and bulimic psychopathology.In: H. Hoek, M. Katzman \& J. Treasure (Eds.), The neurobiological basis of eating disorders (pp. 271-289). Chichester: Wiley.

Mizes, J.S. \& Christiano, B.A. (1995). Assessment of cognitive variables relevant to cognitive behavioral perspectives on anorexia nervosa and bulimia nervosa. Behawiour Research and Therapy, 33, 95-105.

Nauta, H., Hospers, H.J., Jansen, A. \& Kok, G. (2000). Cogbnitions in obese binge eaters and obese non-binge eaters. Cognitive Therapy and Research, 24, 521 531.

Nederkoom, C. \& Jansen, A. (2002). Cue reactivity and regulation of food intake. Earing Behaviors, 3, 61-72.

Nederkoorn, C., Smulder, F.T.Y., \& Jansen, A. (1999). Recording of swallowing events using electromyography as a non-invasive measurement of salivation. Apperite, $33,361-369$.

Nederkoom, C., Smulders, F.T.Y., \& Jansen, A. (2000). Cephalic phase responses, craving and food intake in normal subjects. Appetite, 35, 45-55.

Niaura, R.S., Rohsenow, D.J., Binkoff, J.A., Monti, P.M., Pedraza, M. \& Abrams, D.B. (1988). Relevance of cue reactivity to understanding alcohol and smoking relapse. Jourmal of Abnomal Psychology, 97, 133-152.

Oliver, K.G. \& Huon, G.F. (2001). Eating-related thought suppression in high and low disunhibitors. International Joumal of Eating Disorders, 30, 329-337.

Oyerduin, J., \& Jansen, A. (1996a). A new scale for use in non-clinical research into disinhibitive eating. Pesonality and Individual Difference, 20, 669-677.

Overduin, J., \& Jansen, A. (1996b). Food cue reactivity in fasting and non-fasting subjects. Ewropean Eating Disonders Review, 39, 146-160.

Overduin, J., Jansen, A., \& Eilkes, H. (1997). Cue Reactivity to Food and Body Related Stimuli In Restrained and Unrestrained Eaters. Addictive Behaviors, 22 , $395-404$.

Piacentini, A., Schell, A.M. \& Vanderweele, D.A. (1993). Restrained and nonrestrained eaters' orienting responses to food and nonfood odors. Physiology and Behavior, 53, 133-138.

Polivy, J. \& Herman, C.P. (1985). Dieting and Binging: A causal analysis. American Psychologist, 40, 193-201. 
Polivy, J. \& Herman, C.P. (1993). Etiology of binge eating: Psychological mechanisms. In: C.G. Fairburn \&. G.T. Wilson (Eds.), Binge earing: Nature, assessment and treament. New York: Guilford Press.

Polivy, I., Herman, C.P.., \& McFarlane, T. (1994). Effects of anxiety on eating: Does palatability moderate distress-induced overeating in dieters? Jomal of Abnomal Psychology, 103,505-510.

Pomerleau, O.F., Fertig, J.B., Baker, L., \& Cooney, N. (1983). Reactivity to alcohol cues in alcoholics and non-alcoholics: Implications for a stimulus control analysis of drinking. Addichive Behaviors, 8, 1-10.

Robbins, S.J., Ehrman, R.N., Childress, A.R. \& O'Brien, C.P. (1997). Relationships among physiological and self-report responses produced by cocaine-related cues. Addictive Behavions, 22, 157-167.

Rodin, J. (1985). Insulin levels, hunger, and food intake: An exanple of feedback loops in body weight regulation. Health Psychology, 4, 1-24.

Rogers, P., Anderson, A., Finch, G., Jas, P \& Gatenby, S. (1994). Relationship between food craving and anticipatory salivation, eating patterns, mood and body weight in women and men. Poster session presented at the Society for the Study of Ingestive Behaviour, Second Independent Meeting, MacMaster University, Hamilton, Canada.

Rohsenow, D.J., Niaura, R.S., Childress, A.R., Abrams, D.B. \& Monti, P. M. (1991). Cue reactivity in addictive behaviors: Theoretical and treatment implications. The International Joumal of the Addictions, 25, 957-993.

Rohsenow, D.J., Monti, P.M., Rubonis, A.V., Sirota, A.D., Niaura, R.S., Colby, S.M.* Wunschel, S.M. \& Abrams, D.B. (1994). Cue reactivity as apredictor of drinking among male alcoholics. Journal of Conswling and Clinical Psychology, 62, 620-626.

Romans, S.E., Gendall, K.A., Martin, J.L. \& Mullen, P.E. (2001). Child sexual abuse and later disordered eating: A New Zealand epidemiological study. International Joumal of Eating Disorders, 29, 380-392

Rosen, J.C., Leitenber, H., Fisher, C. \& Khazam, C. (1986). Binge-eating episodes in bulimia nervosa: The amount and type of food consumed. Interwational Lomonal of Eating Disorders, 5, 255-267.

Rosenvinge, J.H., Borgen, J.S. \& Börresen, R. (1999). The prevalence and psychological correlates of anorexia nervosa, bulimia nervosa and binge eating among 15-year-old students: a controlled epidemiological study. European Eating Disoders Review, 7, 382-391.

Rossiter, E.M., Agras, W.S., Telch, C.F. \& Bruce, B. (1992). The eating patterns of non-purging bulimic subjects. International Jowmal of Eating Disorders, II, $111-120$.

Ruchkin, D. S., \& Glaser, E. M. (1976). Simple digital filters for examining CNV and P300 on a single-trial basis. In D. A. Oto (Ed.), Mulfidisciplinairy perspectives in event-related brain potential research. Proceedings of the fow th international congress on event related slow potentials of the brain (EPRC $/ \mathrm{V})$ (pp. 579-605). Hendersonville, North Carolina. 
Schmidt, U., \& Marks, 1. (1988). Cue exposure to food puls response prevention of binges for bulimia: A pilot study. Intemational Jownal of Eating Disorders, 7 . $259-266$.

Secchi, A., Caldara, R., Caumo, A., Monti, L.D., Bonfatti, D., Di Carlo, V. \& Pozza, G. (1995). Cephalic-phase insulin and glucagon release in normal subjects and in patients receiving pancreas transplantation. Metabolism, 44, 1153-1158.

Siegel, S. (1983). Classical conditioning and drug effect. In: R. Smart, F. Glaser, Y. Isreal, H. Kalant, R. Popham and W, Schmidt (Eds.), Research Advances in Alcohol and Drug Problems (pp 207-246). New Yoork: Plenum Press.

Siegel, S. (1989). Pharmacological Conditioning and Drug Effects. In A. J. Goudie M.W. Emmett-Oglesby (Eds). Psychoactive Drugs: Tolerance and Sensitization. (pp. 115-180). Cilfton, New Jersey: Humana Press.

SiegeI, W.E., \& Hagen, R.L. (1982). The Infuence of Demand Characteristics and Expectancies in the Measurement of Salivary Response. Jowmal of Behavioral Assessment, 4, 179-185.

Sjôvall, H., Forssell, H., Haggendal, J., \& Olbe, L. (1990). Attenuation of gastric sham feeding response during reflex sympathetic activation in man. Scandinarian Jounal of Gastroenterology, 25, 73-80.

Spitzer, R.L., Williams, J.B.W., Gibbon, M. \& First, M.B. (1990). User's guide for the struchured clinical interview for DSM-IIT-R: SCID. Washington, DC: American Psychiatric Press, Inc.

Staiger, P., Dawe, S. \& McCarthy, R. (2000). Responsivity to food cues in bulimic women and controls. Appetite, 35,27-33.

Stern, R. M., Crawford, H. E., Stewart, W. R., Vasey, M. W., \& Koch, K. L. (1989). Sham feeding. Cephalic-vagal influences on gastric myoelectric activity. Dig Dis Sci, 34, 521-7.

Stewart, J., de Wit, H. \& Eikelboom, R. (1984). Role of unconditioned and conditioned drug effects in the self-administration of opiates and stimulants. Psychological Review, 91, 251-268

Striegel-Moote, R.H., Silberstein, L.R. \& Rodin, J. (1986). Toward an understanding of risk factors for bullinia. AmericamPsychologist, 41, 246-263.

Swift, W.J., Andrews, D. \& Barklage, N.E. (1986). The relationship between affective disorder and eating disorders: A review of the literature. American Joumal of Psychiarry, 143, 290-299

Tef, K.L. \& Engelman, K. (1996). Palatability and dietary restraint: Effect on ceplualic phase insulin release in women. Physiology \& Behavior, 60, 567-573.

Teff, K.L., Mattes, R.D., \& Engelman, K. (1991). Cephalic phase insulin release in normal weight males: verification and reliability. American Journal of Physiogyl. 261, E430-E436.

Tepper, B.J. (1992). Dietary restraint and responsiveness to sensory-based food cues as measured by cephalic phase salivation and sensory specific satiety. Physiology \& Behavior, 52, 305-311.

Tiffany, S.T. (1995). Potential functions of classical conditioning in drug addiction. In: D.C. Drummond, S.T. Tiffany, S. Glautier \& B. Remington (Eds.), Addictive behaviour: Cue exposwe theory and practice,(pp 47-71). Chichester. Wiley. 
Tuomisto, T., Hetherington, M.M., Morris, M., Tuomisto, M.T., Turjanmaa, V. \& Lappalainen, R. (1999). Psychological and physiological characteristics of sweet food "addiction". International Jownal of Eating Disorders, 25, 169-1.75.

Vaz, M., Turner, A., Kingwell, B., Chin, J., Koff, E., Cox, H., Jennings, G. \& Esler, M. (1995). Postprandial sympatho-adrenal activity: its relation to metabolic and cardiovascular events and to changes in meal frequency. Chincal Science, 89 . 349-347.

Vögele, C., \& Florin, 1. (1997). Psychophysiological Responses to Food Exposure: An Experimental Study in Binge Eaters. Internation Jownal of Earing Disordors, $21,147-157$.

Walitzer, K.S., \& Sher, K.J. (1990). Alcohol Cue Reactivity and Ad Lib Drinking in Young Men at Risk for Alcoholism. Addictive Behaviors, 15, 29-46.

Walsh, B.T. (1993). Binge eating in bulimia nervosa. In: C.G. Fairburn \& G. T. Wilson (Eds.), Binge eating: Nature, Assessment, and Treatment (pp. 37-49), New York: Guilford Press.

Ward, A. \& Mann, T. (2000). Don't mind if I do: Disinnibited eating under cognitive load. Journal of Personality and Social Psychology. 78, 753-763.

Wardle, J. (1990). Conditioning processes and cue exposure in the modification of excessive eating. Behaviour Therapy World Congress: Cue exposure in the addictive behaviors (1988, Edinburgh, Scotland). Addictive Behoviors, 15,387 393.

Wardle, J. \& Beinhart, H. (1981). Binge eating: A theoretical review. British Joumal of Cinical Psychology, 20,97-109.

Waters, A., Hill, A. \& Waller, G. (2000). Internal and external antecedents of binge eating episodes in a group of women with bulimia nervosa. Intenational Journal of Eating Disonders, 29, 17-22.

Waters, A., Hill, A. \& Waller, G. (2001). Bulimics' responses to food cravings: is binge-eating a product of hunger or emotional state? Behaviour Research and Therapy, 39, 877-886.

Wegner, D.M. (1994). Ironic processes of mental control. Psychologicul Review, 101. 34-52.

Wegner, D.M. \& Zanakos, S. (1994). Chronic thought suppression. Iowy af Personality: 62, 615-640.

Westerhoefer, J, (2001). Prevalence of eating disorders and weight contiol practices in Gernany in 1990 and 1997. Mnternational Jonmal of Eaving Disorders, 29, 477481 .

Westerterp Plantenga, M. S., Wouters, L.. \& ten Hoor, F. (1990). Deceleration in cumblative food intake curves, changes in body temperature and die-induced thermogenesis. Physiology and Behavior, 48, $831-6$.

White, K.D. (1977). Salivation: A review and experimental investigation of major techniques. Psychophysiology, 14.203-212.

Wikler, A. (1980). Opiod dependence: Mechanisms and treaments. New York: Plenum Press.

Wilson, J.F. \& Mercer, J.C. (1990). An electrophysiological correlate of Eating Attitude Test scores in female college students. Psychological Medicine, 20 , 973-975. 
Woods, S.C. (1991). The eating paradox: How we tolerate food. Psychological Review, 98,488-505.

Woods, S.C \& Strubbe, J.H. (1994). The psychobiology of meals. Psychonomic Bullevin de Review, 1, 141-155.

Wooley, O.W., \& Wooley, S.C. (1981). Relationship of salivation in humans to deprivation, imhibition and the encephalization of hunger. Appetite, 2, 331-350.

Wooley, S.C., \& Wooley, O.W. (1973). Salivation to the sight and thought of food: a new measure of appetite. Psychosomatic Medicine, 35, 136-142.

Wooley, O.W., Wooley, S.C. \& Dunham, R.B. (1976) Deprivation, expectation and threat: Effects on salivation in the obese and nonobese. Physiology and Behavior, 17, 187-193.

Wooley, O.W., Wooley, S.C., \& Williams, B.S.(1975). Salivation as a measure of appetite: studies of the anorectic effects of calories and amphetamine. In Novin D et al. (Ed.), Hunger: basic mechanisms and clinical implications. (pp. 421 429). New York: Raven Press.

Zellner, D.A. \& Edwards, E.M. (2001). Conditioning models of food craving. In Marion M. Hetherington (Ed), Food cravings and addiction.(pp. 171-234). Surrey: Leatherhead Publishing. 


\section{Dankwoord}

Het is zover: Sjaan gaat 'afstuderen". En dit uiteraard dankzij de medewerking van velen.

Als eerste de initiator van mijn project: Dame Anita. Door jou werd wetenschap een groot feest! Dit zowel door goede begeleiding en je grote enthousiasme voor experimenteel onderzoek als door de vriendschap en vrijheid die je bood. Ik hoop daarom nog lang met je samen te werken!

Dan alle proefpersonen. Gewillig lieten zij zich volplakken met elektroden en volhardend roken zij aan lasagna, snoep en andere zaken. Zeker voor de bulimia patienten was het vaak een moeilijke confrontatie, mijn grote dank dat zij toch mee wilden werken.

Hulp bij het testen van proefpersonen kreeg ik van Tessa de Wit en Annic Raven. Technische ondersteuning, hulp bij software, data-analyse en eindeloze conversies kreeg ik van Huub Hamers, Marcel Hendrickx, Ron Hellebrand, Johan Gielissen, Theo van Aerts, Bert Hoekzema, Peter de Jong en Fren Smulders. Marja, Truus en Nicole, voor een chaoot als ik was secretariële ondersteuning onmisbaar. Verder was het onderzoek met de bulimia's was onmogelijk zonder de betrokkenheid en inzet van Han Keysers, alle psychotherapeuten van de geacademiseerde afdeling cognitieve gedragstherapie wan de RIAGG Maastricht en uiteraard Anja Meijboom. ledereen heel erg bedankt!

Collega's, mede-aio's, dames van het eetgroepje, het was en is prettig met jullie samen te werken. Marja, Joost en kinderen, jullie gastvrijheid is niet te evenaren. Ook iedereen bedankt die met ping-pong, koffietijd of kroegbezoek afleiding bracht. Mijn paranimfen, Remco en Yol, het is fijn dat jullie in deze spannende tijden naast me staan. Lieve ouders, vrienden, familie en natuurlijk Pieter en Floor: niet dit proefschrift, maar jullic maken het verschil! 


\section{Curriculum Vitae}

Chantal Nederkoorn werd geboren op 12 maart 1972 in Amstelveen. In 1990 liatalde zij het VWO-diploma aan de Gemeentelijke Scholen Gemeenschap Doetinchem. Daarna ging zij psychologie studeren aan de UrA te Amsterdam. In 1996 studeerde ze af in de richting psychonomie. In 1997 werd Chantal aangesteld als AIO aan de Faculteit der Psychologie, Universiteit Maastricht. Het onderzoek in dit proefschrift is tijdens deze aanstelling witgevoerd en opgeschreven. Vanaf februari 2002 is zij werkzaam als universitair docent aan dezelfde faculteit. 